\title{
Originalism and Interpretive Conventions
}

\author{
Caleb Nelson $\dagger$
}

In all living languages, the conventional usages of individual words change over time. For illustrations, one need only consult the Oxford English Dictionary, which arranges its definitions of each word so that they proceed from the earliest usages to those that were introduced more recently.'

This aspect of language change raises an obvious issue for the interpretation of our written constitutions. The federal Constitution, in particular, was "intended to endure for ages to come," and it seems inevitable that some of the words it uses will acquire new connotations from one age to the next. So-called "originalists" have focused on this issue and have staked out a clear position: They believe in enforcing the Constitution's "original meaning" rather than whatever meaning the same words would have if adopted today. Originalists accordingly emphasize old dictionaries and other evidence of how the words in the Constitution were used at the time of the founding."

What originalists think of as a law's "original meaning," though, does not depend solely upon the dictionary definitions of the individual words that the law uses. It also depends upon a variety of other linguistic conventions. Some of those conventions are part of the English language in general; to understand almost any document written in English, one needs to know not only the conventional usages of individual words, but also the grammatical rules that govern how words are combined and the interpretive principles that tell us which inferences are appropriate in which circumstances. Other conventions are

$\dagger$ Associate Professor, University of Virginia School of Law. My thinking on the issues addressed in this Article has benefited enormously from conversations with John Harrison. For helpful comments on drafts, I am also indebted to Daryl Levinson, David Nelson, Jim Ryan, G. Edward White, Ann Woolhandler, and participants in workshops at the University of Virginia and the University of Chicago. All errors, of course, are my own.

1 See 1 Oxford English Dictionary xxix (2d ed 1989). But see Muscarello v United States, 524 US 125, 128, 130 (1998) (assuming inaccurately that the first definition listed in the Oxford English Dictionary is the word's "primary meaning" in current usage, and chiding the dissenting justices for reading a statutory term in the sense suggested by one of the later definitions).

$2 \quad$ M'Culloch $v$ Maryland, 17 US (4 Wheat) 316, 415 (1819).

3 See, for example, Office of Legal Policy, Original Meaning Jurisprudence: $A$ Sourcebook 9 (US Department of Justice 1987).

4 See Nicholas Quinn Rosenkranz, Federal Rules of Statutory Interpretation, 115 Harv L $\operatorname{Rev} 2085,2142$ (2002) ("[M] eaning derives from the interaction of a text and an interpretive regime."). 
more specialized; in construing legal documents, lawyers use various canons that laymen might not recognize. Conventions of both sorts form part of the background against which laws are drafted and understood, and they can greatly affect what a law is taken to say.

Like the conventional usages of individual words, these conventions too are mutable. Rules that legal draftsmen and interpreters alike once followed may fall out of fashion. Even the basic attitude that interpreters are expected to adopt-and upon which draftsmen may therefore rely - can vary over time. The "original meaning" of a law enacted when interpreters are expected to adhere strictly to the law's explicit text may differ markedly from the "original meaning" of the identical words enacted when interpreters are expected to infer exceptions or embellishments on the basis of the law's apparent purposes.

Even if the basic principles of interpretation remain constant, the specific canons that those principles support can be different in different times. For example, many canons of construction reflect the sensible principle that interpreters should not be too quick to read a law to do something strange; other things being equal, they should prefer readings that comport with prevailing attitudes or established practices.' Yet what is extraordinary in one age may not be so strange in another. Interpretive conventions based on attitudes toward federalism, for instance, may well have been different after the Civil War than they were at the time of the founding; thus, even though Section 5 of the Fourteenth Amendment and the Necessary and Proper Clause of Article I are cast in similar terms, Section 5 may be understood to give Congress more coercive power over the states. ${ }^{8}$

Despite the importance of interpretive conventions to their project, originalists have made little systematic effort to identify the kinds of conventions that bear on what they think of as the Constitution's "meaning," or to investigate the content of such conventions at the

5 See, for example, Caleb Nelson, Preemption, 86 Va L Rev 225, 237-44 (2000) (discussing "non obstante clauses," a device by which eighteenth-century draftsmen opted out of the presumption against implied repeals); id at 254-60, 292-98 (explaining how familiarity with this device sheds light on the original meaning of the Supremacy Clause, which includes a non obstante provision).

6 See note 188 (noting the debate between Professors John Manning and William Eskridge about founding-era attitudes toward this issue in the context of statutory interpretation).

7 See, for example, Landgraf v USI Film Products, 511 US 244, 272-73 (1994) (applying the presumption against retroactivity as a "background rule" that "accords with widely held intuitions about how statutes ordinarily operate").

8 See Caleb Nelson, Sovereign Immunity as a Doctrine of Personal Jurisdiction, $115 \mathrm{Harv}$ L Rev 1559, 1643 n 358 (2002). (suggesting this explanation for the current Supreme Court's view that Section 5 authorizes Congress to expose states to suit by individuals but that the Necessary and Proper Clause does not). 
time of the founding. To the extent that originalists have addressed these topics at all, they have done so chiefly in response to critics who claim that members of the founding generation "expected the meaning of the Constitution to evolve," that this expectation was itself built into what originalists would consider the Constitution's original "meaning," and that the internal logic of originalism therefore "selfdestructs." Originalists have offered some effective rebuttals of this argument's historical and jurisprudential premises, but they have not gone further; originalist attention to founding-era interpretive approaches has focused largely on founding-era attitudes toward originalism itself.

Part I of this Article revisits the issue that originalists and their critics have already debated and advances some additional evidence for the proposition that originalism does not self-destruct. To be sure, James Madison and other prominent founders did not consider the Constitution's meaning to be fully settled at the moment it was written. They recognized that it contained ambiguities and that subsequent interpreters would help "fix" its meaning on disputed points. Contrary to the suggestion of some critics, though, they did not envision a perpetually evolving meaning on each of these points. Once practice had settled upon one of the possible interpretations of a disputed provision, they expected that interpretation to persist. Their talk of "fixing" the Constitution's meaning makes this expectation clear; as we shall see, it resonates with discussions of language change that were at the forefront of eighteenth-century lexicography. For the founding generation's men of letters, the concept of "fixing" meaning connoted permanence and immutability.

After clarifying founding-era expectations about the role of subsequent interpreters in fixing the Constitution's meaning, Part I closes with a brief discussion of whether present-day originalists are logically bound to honor those expectations. Some of the founding era's legal and linguistic practices unquestionably bear on what all originalists think of as the Constitution's "meaning." But the founders' expectations about how indeterminacies in the Constitution would be re-

9 Erwin Chemerinsky, Interpreting the Constitution 62-63 (Praeger 1987). See also, for example, Leonard W. Levy, Original Intent and the Framers' Constitution 331-32 (Macmillan 1988):

[N]o evidence, not a shred, exists to show that the Framers meant, wanted, or expected future generations to construe the Constitution as they, the Framers, had. Nor is there any evidence to show that they expected the future to be bound by the past. Rather, they expected the future to interpret the Constitution as best it could, just as the development of the common law was left open.

See also Joseph R. Biden, Jr., Law and Natural Law: Questions for Judge Thomas, Wash Post C1 (Sept 8,1991) (asserting that "such founders as Jefferson and Madison" rejected the view that "the meaning of the Constitution would be static"). 
solved probably occupy a border zone; different versions of originalism can take different positions about their continuing relevance.

Part II turns to the kinds of interpretive conventions that unquestionably do help define the "original meaning" that originalists are committed to enforcing. Here, I argue, originalists encounter an unexpected problem: The applicable conventions were not fully settled at the time of ratification, and the Constitution's "meaning" was correspondingly open to even more debate than originalists usually concede. Among other difficulties, founding-era interpretive conventions differed for different types of legal documents, and it was not clear whether the Constitution should be interpreted like a treaty, a statute, a contract, or something else. While all types of legal interpretation did share certain elements, and while these common elements defined a range of possible approaches to the Constitution, that range left ample room for interpretive disagreements.

Without tracking such disagreements to their sources, critics of originalism often cite them as proof that originalism is incoherent or unworkable. After all, to the extent that members of the founding generation disagreed with each other about how to interpret the Constitution, there might be no "original meaning" for subsequent courts to discover. ${ }^{10}$ The standard originalist response has been to distinguish between the "subjective" intentions of individual members of the founding generation and the "objective" meaning of the text, and to suggest that the critics' argument relates exclusively to the former. For reasons developed in Part II, this distinction is not as helpful to the originalists' cause as originalists sometimes suggest. But as Part II goes on to explain, evidence of widespread interpretive disagreements among members of the founding generation does not doom the originalist project. To the contrary, such disagreements were an expected part of the process of "fixing" the Constitution's meaning. The document's early interpreters -including not just the courts, but also legislatures, executive officials, the state ratifying conventions, and members of the public at large-helped both to narrow the range of accepted interpretive approaches and to settle discrete questions about particular provisions. To the extent that one accepts this process, the passage of time actually eliminated some of the indeterminacies that had initially plagued the Constitution. Thus, the unsettled nature of the interpretive conventions discussed in Part II may encourage some originalists to embrace the concept of "fixing" meaning discussed in Part I.

Even for originalists who accept that concept, of course, the passage of time is not a panacea; changing circumstances permit new in- 
determinacies to surface even as old indeterminacies are being resolved. Part III briefly discusses a few of the many reasons why present-day originalists will continue to confront unresolved indeterminacies.

Whether the fact of indeterminacy defeats the normative case for originalism is a question that lies well beyond the scope of this Article. People certainly should not embrace originalism in the false belief that it will provide determinate answers to all questions of constitutional interpretation; neither originalism nor any other plausible approach to the Constitution can do so. But sophisticated originalists have advanced a variety of arguments that, in their view, justify originalism even in the face of indeterminacy." This Article does not purport to evaluate those arguments. Instead, it is written for people who accept them, and who have therefore decided to embark on the originalist project. My goal is to consider how founding-era interpretive conventions affect that project.

\section{THE Notion OF AN INVARIANT MEANING}

The idea that originalism cannot be reconciled with the interpretive conventions prevailing at the time of the founding relies on the work of Professor H. Jefferson Powell, though Powell himself is too careful a scholar to make the claim so broadly. In one of the mostcited law review articles of recent years, Powell discussed the original "interpretive intentions"- the founders' expectations about the manner in which interpreters would determine the Constitution's meaning. ${ }^{12}$ As Powell observed, one of the "most obvious sources of hermeneutical wisdom" in late eighteenth-century America was the general common law, which included a variety of rules for interpreting different types of legal documents. ${ }^{13}$ In the argot of the day, people said that they used those rules to determine the "intent" of the document in question. ${ }^{14}$ According to Powell, however, "[t]he late eighteenth cen-

11 See Keith E. Whittington, Constitutional Interpretation: Textual Meaning, Original Intent, and Judicial Review 77, 89-109 (Kansas 1999). See also id at 4 ("Our expectations for an originalist jurisprudence must be lowered so that it can be evaluated more realistically and advocated more persuasively.").

12 H. Jefferson Powell, The Original Understanding of Original Intent, 98 Harv L Rev 885 (1985). See also Fred R. Shapiro, The Most-Cited Law Review Articles Revisited, 71 Chi Kent L Rev 751, 774 (1996) (listing Powell's piece as one of the most frequently cited articles of recent years); Philip Bobbitt, Constitutional Interpretation 123 (Blackwell 1991) (calling Powell's piece "perhaps the most influential article of the [1980s]"). The phrase "interpretive intention" comes from Paul Brest, The Misconceived Quest for the Original Understanding, 60 BU L Rev 204, 215 (1980), which is itself one of the most-cited law review articles of all time. See Shapiro, 71 Chi Kent $L$ Rev at 768.

13 Powell, 98 Harv L Rev at 889 (cited in note 12).

14 See id at 894 ("The concept central to the common law's hermeneutic ... was the notion of the 'intention' or 'intent' underlying a text."). 
tury common lawyer conceived an instrument's 'intent'-and therefore its meaning - not as what the drafters meant by their words but rather as what judges, employing the 'artificial reason and judgment of law,' understood 'the reasonable and legal meaning' of those words to be"; $;$ the term "referred to the meaning an interpreter was entitled to derive from the document using the common law's techniques of construction., ${ }^{16}$

Nothing thus far in Powell's argument conflicts with the originalist's quest for an "original meaning" that persists throughout the ages." But Powell went on to suggest that under the techniques of construction that the framers expected courts to apply, the meaning of a legal document could vary over time. In his words, the "old common law assumption, shared by the Philadelphia framers," was that "the 'intent' of any legal document is the product of the interpretive process and not some fixed meaning that the author locks into the document's text at the outset." 18

Because of statements of this sort, Powell's article is often taken to argue that "originalism refutes originalism"-that if one interprets the Constitution as the founding generation expected and as the accepted interpretive techniques of the day dictated, one will enforce a "living Constitution" whose meaning is never frozen but instead continues to evolve over time..$^{19}$ Erwin Chemerinsky, for instance, describes Powell's article as "a powerful argument that the framers[] intended non-originalist review." ${ }^{20}$ Laura Kalman likewise takes Powell's

15 Id at 895-96 (footnotes omitted).

16 H. Jefferson Powell, The Modern Misunderstanding of Original Intent, $54 \mathrm{U}$ Chi L Rev 1513,1534 (1987).

17 See, for example, Office of Legal Policy, Original Meaning Jurisprudence at 23 (cited in note 3) ("Far from undermining modern interpretivism, Powell's research shows that original meaning jurisprudence based on the text of the Constitution is completely consistent with the founders['] expectations.").

18 Powell, 98 Harv L Rev at 910 (cited in note 12).

19 See Barry Friedman and Scott B. Smith, The Sedimentary Constitution, 147 U Pa L Rev 1,29 (1998) (glossing Powell's article as using originalism to support "living constitutionalism"). See also, for example, Wendy Ann Semel, Book Note, Defender of the Natural Rights Faith, 105 Yale L J 1427, 1427 n 2 (1996) (glossing Powell's article as arguing that "[the] Framers intended [the] Constitution to evolve through its interpretation in accordance with modern conditions and values"); Harry H. Wellington, Interpreting the Constitution: The Supreme Court and the Process of Adjudication 50-51 (Yale 1990) (suggesting that after the publication of Powell's article, "[n]o longer can [modern interpreters] see themselves as being under an obligation to obey the commands of the founding fathers").

20 Erwin Chemerinsky, A Different Vision of Judicial Review: In Tribute to Professor Grano, 46 Wayne L Rev 1403, 1410 n 61 (2000). See also, for example, Christopher L. Eisgruber, Early Interpretations \& Original Sins, 95 Mich L Rev 2005, 2017 n 16 (1997) (glossing Powell's article as "arguing that the Founders were not originalists"); Michael J. Gerhardt, Interpreting Bork, 75 Cornell L Rev 1358, 1382 (1990) (asserting that Powell's article "demonstrates that there is no evidence that the framers favored using original understanding in constitutional interpretation"). 
article to show that "originalism was ... not the original understanding." ${ }^{2 t}$

Originalists have offered two basic responses to this claim: (1) it isn't true, ${ }^{2}$ and (2) it doesn't matter anyway. ${ }^{23}$ As we shall see, some versions of originalism may not really be able to offer the second of these responses; their normative justifications do make it important to follow founding-era expectations about how future interpreters would approach the Constitution. But even these versions of originalism can avoid self-contradiction if the first response is sound. In what follows, I try to shed some new light on that issue by linking founding-era discussions of constitutional interpretation to eighteenth-century debates about language change. I conclude that there is at least some sense in which members of the founding generation expected the Constitution's meaning to be invariant over time.

\section{A. Originalism and the Role of Postenactment Interpretation}

1. Early talk about "fixing" the meaning of ambiguous provisions.

To put the relevant discussions in their proper context, we need to start with some familiar history. During the ratification debates, Anti-Federalists complained that the Constitution's language was ambiguous and obscure. ${ }^{24}$ The Constitution's supporters responded that

21 Laura Kalman, Border Patrol: Reflections on the Turn to History in Legal Scholarship, 66 Fordham L Rev 87, 94 \& n 48 (1997).

22 See Charles A. Lofgren, The Original Understanding of Original Intent?, 5 Const Commen 77,79 (1988) (reviewing Powell's evidence and concluding that "although the originators rejected the use of framer intent, ... they were clearly hospitable to the use of original intent in the sense of ratifier intent"); Richard S. Kay, Adherence to the Original Intentions in Constitutional Adjudication: Three Objections and Responses, $82 \mathrm{Nw}$ U L Rev 226, 281 (1988) (doubting the historical accuracy of "the argument that the constitution-makers did not want their intentions to bind future generations," and identifying a "pervasive" view among the founders "that the virtue of a written constitution lay in its capacity to fix the limits of proper governmental action"). Compare Robert N. Clinton, Original Understanding, Legal Realism, and the Interpretation of "This Constitution", 72 Iowa L Rev 1177, 1220 (1987) (concluding that the historical record is mixed: "Originalism [ ] neither was demonstrably originally intended as an exclusive interpretive methodology, as some modern originalists imply, nor was [ ] unknown to the framers and early interpreters of the Constitution, as argued by Professor Powell.").

23 See Whittington, Constitutional Interpretation at 181-82 (cited in note 11). Compare Gregory Bassham, Original Intent and the Constitution: A Philosophical Study 70 (Rowman \& Littlefield 1992) (arguing that "the soundest form of originalism ... does not accord binding authority to the framers' interpretive intentions").

24 See Philip A. Hamburger, The Constitution's Accommodation of Social Change, 88 Mich L Rev 239, 307 \& n 254 (1989) (citing illustrations). See, for example, Debates of the Virginia Convention (June 5, 1788), in John P. Kaminski and Gaspare J. Saladino, eds, 9 The Documentary History of the Ratification of the Constitution 943, 953 (State Historical Society of Wisconsin 1990) (reporting Patrick Henry's complaints that the Constitution was clear when it gave power to the federal government but ambiguous when it talked about the privileges of the people); Debates of the Virginia Convention (June 7, 1788), in Kaminski and Saladino, eds, 9 Documentary 
the document had been drafted with as much precision as possible, but they acknowledged that some indeterminacy was inevitable. In Federalist 37, James Madison argued that even superhuman drafters could not have produced a perfectly precise document, since "no language is so copious as to supply words and phrases for every complex idea, or so correct as not to include many equivocally denoting different ideas." ${ }^{26}$ The fact that the political system envisioned by the framers was "novel and unique" only exacerbated this problem. As Madison explained in a later letter, the vocabulary that existed at the time of the framing was geared to the "known ideas" of the day, but the framers were trying to describe "new ideas"; such innovations "must be expressed either by new words, or by old words with new definitions." ", Thus, "[i]t ... was foreseen at the birth of the Constitution, that difficulties and differences of opinion might occasionally arise in expounding terms and phrases necessarily used in such a charter ....,28

History of the Ratification 1006, 1046 (same); Debates of the Virginia Convention (June 21,1788), in John P. Kaminski and Gaspare J. Saladino, eds, 10 The Documentary History of the Ratification of the Constitution 1440,1446-47 (State Historical Society of Wisconsin 1993) (reporting William Grayson's objection that Article III "is not expressed in a definite manner" and that the grant of "arising under" jurisdiction in particular "is so vaguely and indefinitely expressed, that its latitude cannot be ascertained"); Theophilus Parsons, Notes of Convention Debates (Jan 21, 1788), in John P. Kaminski and Gaspare J. Saladino, eds, 6 The Documentary History of the Ratification of the Constitution 1294, 1297 (State Historical Society of Wisconsin 2000) (remarks of Samuel Thompson at the Massachusetts convention) ("The Constitution is in doubtful terms; it can't be understood."); Brutus XI, NY J (Jan 31, 1788), reprinted in John P. Kaminski and Gaspare J. Saladino, eds, 15 The Documentary History of the Ratification of the Constitution 512, 515 (State Historical Society of Wisconsin 1984) ("Most of the articles in this system, which convey powers of any considerable importance, are conceived in general and indefinite terms, which are either equivocal, ambiguous, or which require long definitions to unfold the extent of their meaning."); id at 513 (noting that in setting forth the federal government's judicial powers, the Constitution used "[a] number of hard words and technical phrases ... about the meaning of which gentlemen learned in the law differ"). See also The Daily Advertiser (June 22,1789), reprinted in Charlene Bangs Bickford, Kenneth R. Bowling, and Helen E. Veit, eds, 11 Documentary History of the First Federal Congress of the United States of America 895, 902 (Johns Hopkins 1992) (remarks of Rep Elbridge Gerry on June 17, 1789) (continuing to maintain that the Constitution "was in many parts obscure and unintelligible," and observing that "[t]his obscurity had been one of the great arguments against accepting it").

25 See Hamburger, 88 Mich L Rev at 308 \& n 261 (cited in note 24) (collecting sources).

26 Federalist 37 (Madison), in Jacob E. Cooke, ed, The Federalist 231, 236 (Wesleyan 1961).

27 Letter from James Madison to Edward Livingston (Apr 17, 1824), in 3 Letters and Other Writings of James Madison 435, 436 (J.B. Lippincott 1865). See also Federalist 37 at 236 (cited in note 26 ) (indicating that the "unavoidable inaccuracy" generated by the defects in human language was all the greater because of the "complexity and novelty of the objects defined" by the Constitution); Letter from James Madison to N.P. Trist (Dec 1831), in 4 Letters and Other Writings of James Madison 204, 209 (J.B. Lippincott 1865) ("[T]he Government of the United States, being a novelty and a compound, had no technical terms or phrases appropriate to it, and [] old terms were to be used in new senses, explained by the context or by the facts of the case.").

28 Letter from James Madison to Spencer Roane (Sept 2, 1819), in 3 Letters of Madison 143,145 (cited in note 27). 
As Professor Powell notes, Madison and his contemporaries expected the practice that developed under the Constitution to "liquidate and settle the meaning" of these contestable provisions. ${ }^{29}$ In this respect, the Constitution resembled other "new laws," which must all be "considered as more or less obscure and equivocal, until their meaning be liquidated and ascertained by a series of particular discussions and adjudications." ${ }^{30}$

For Madison, the relevant "discussions and adjudications" were not confined to interpretations adopted by the judiciary; other sufficiently deliberate constructions of the Constitution could also help "settle[]" the document's meaning. ${ }^{31}$ One of the "doubtful point[s]" in the Constitution, for instance, concerned the President's authority to fire executive-branch officers. ${ }^{32}$ When the First Congress considered legislation to organize the executive branch, members of the House of Representatives debated what the Constitution should be understood to say about this issue. During the course of the debates, Representative Madison reminded his colleagues that the conclusion reflected in their statute would have lasting impact as a "permanent exposition of the constitution." ${ }^{33}$

Madison did not think that all legislative precedents should have this effect. To the contrary, he told one correspondent that "legislative precedents are frequently of a character entitled to little respect," because statutes often were passed with little deliberation. ${ }^{34}$ Statutes

29 Id. See also, for example, Federalist 82 (Hamilton), in The Federalist 553, 553 (cited in note 26) (indicating that only time could "liquidate the meaning of all the parts" of the system erected by the Constitution).

30 Federalist 37 at 236 (cited in note 26). See also Letter from Madison to Roane at 143 (cited in note 28) ("I have always supposed that the meaning of a law, and ... of a constitution, so far as it depends on judicial interpretation, was to result from a course of particular decisions, and not those from a previous and abstract comment on the subject.").

31 See, for example, Letter from James Madison to Samuel Johnston (June 21, 1789), in Charles F. Hobson and Robert A. Rutland, eds, 12 The Papers of James Madison 249, 250 (Virginia 1979).

32 The Congressional Register (June 18, 1789), reprinted in Bickford, Bowling, and Veit, eds, 11 Documentary History of the First Congress 951, 967 (cited in note 24) (remarks of Rep Elias Boudinot). See also Letter from James Madison to Edmund Pendleton (June 21, 1789), in Hobson and Rutland, eds, 12 Papers of Madison 251, 252 (cited in note 31) (reporting debates on this issue and noting that " $[\mathrm{t}]$ he Constitution has omitted to declare expressly by what authority removals from office are to be made").

33 Different reports of Madison's speech use slightly varying language. Contrast The Congressional Register (June 17, 1789), reprinted in Bickford, Bowling, and Veit, eds, 11 Documentary History of the First Congress 904, 921 (cited in note 24) ("I feel the importance of the question, and know that our decision will involve the decision of all similar cases. The decision that is at this time made will become the permanent exposition of the constitution ...."), with Daily Advertiser (June 22,1789) at 895 (cited in note 24) ("I feel the importance of the question before us, as our decision will be a permanent exposition of the constitution in this point ....").

34 Letter from James Madison to Spencer Roane (May 6, 1821), in 3 Letters of Madison 217,221 (cited in note 27). See also id: 
should not be taken to settle constitutional questions that members of the enacting Congresses had examined only "slightly, if at all." But when members of Congress really deliberated about some contestable question of interpretation - as they did with respect to the President's power to remove executive officers or Congress's power to create the first Bank of the United States ${ }^{36}$ - the expositions that they adopted could help to "fix[]" the Constitution's meaning." Just as judicial precedents that were "formed on due discussion and consideration" (and that were then "deliberately sanctioned by reviews and repetitions") could be "of authoritative force in settling the meaning of a law," so too a series of legislative precedents could have the same effect.

In resorting to legal precedents as sanctions to power, the distinctions should ever be strictly attended to between such as take place under transitory impressions, or without full examination and deliberation, and such as pass with solemnities and repetitions sufficient to imply a concurrence of the judgment and the will of those who, having granted the power, have the ultimate right to explain the grant.

35 Letter from James Madison to James Monroe (Dec 27, 1817), in 3 Letters of Madison 54, 55 (cited in note 27). See also id at 56 :

Serious danger seems to be threatened to the genuine sense of the Constitution, not only by an unwarrantable latitude of construction, but by the use made of precedents which cannot be supposed to have had in the view of their Authors the bearing contended for, and even where they may have crept through inadvertence into acts of Congress, and been signed by the Executive at a midnight hour, in the midst of a group scarcely admitting perusal, and under a weariness of mind as little admitting a vigilant attention.

Compare Everett Somerville Brown, ed, William Plumer's Memorandum of Proceedings in the United States Senate, 1803-1807 80 (Macmillan 1923) (entry of Dec 12, 1803) (acknowledging that past congressional practice cut against the idea that proposed constitutional amendments must be presented to the President before they can be sent to the states for ratification, but asserting that these precedents "prove nothing" because they were "established without debate, or without a particular attention to the subject"), quoted in David P. Currie, The Constitution in Congress: The Jeffersonians, 1801-1829 58 (Chicago 2001).

36 See, for example, Powell, 98 Harv L Rev at 939-41 (cited in note 12) (discussing Madison's explanation for his administration's decision not to veto the Second Bank of the United States on constitutional grounds). See also $M^{\prime}$ Culloch $v$ Maryland, 17 US (4 Wheat) 316, 401-02 (1819) (asserting that "the practice of the government" from the First Congress to the present should at least have considerable weight in resolving "a doubtful question" like the constitutionality of the bank).

37 Letter from James Madison to Charles J. Ingersoll (June 25, 1831), in 4 Letters of Madison $183,184-86$ (cited in note 27 ).

38 Id. Some members of the founding generation, indeed, thought that the political branches (and, by extension, the people themselves) should have exclusive responsibility for settling the Constitution's indeterminacies, and that courts should play no role in this process. In 1795 , Zephaniah Swift built upon this premise to argue against the institution of judicial review as a whole. The great Connecticut jurist acknowledged the argument that "if there be no bounds set to the power of the legislature, in construing the constitution," then the legislature might pass laws that were "manifestly unconstitutional." But he responded that judicial review was just as likely to create the opposite problem; judges might refuse to apply laws that plainly were within the legislature's authority. In his view, neither of these problems was likely: "[N]o question will ever arise in very clear cases." Instead, the institution of judicial review would matter only when, because of "the imperfection of language," the Constitution was "ambiguous" and "good men 
Indeed, Madison thought that there could be no serious dispute about the relevance of post-enactment interpretations in settling the Constitution's meaning. "None will deny," he asserted in one 1831 letter, "that precedents of a certain description fix the interpretation of a law." "In keeping with this assessment, Madison's contemporaries likewise made repeated references to the role of practice in "fixing" the Constitution's meaning.

may very honestly differ respecting [its] construction." To the extent that such ambiguities led to interpretive disagreements between legislatures and courts, Swift thought that the legislative interpretation should be "final and conclusive" upon the judiciary. Swift based this conclusion largely on the differences between the institutional arrangements under which each branch operated. In particular, elections made legislators "responsible to the people" in a way that judges often were not. See Zephaniah Swift, 1 A System of the Laws of the State of Connecticut 51-53 (Byrne 1795).

Swift acknowledged that the idea of judicial review was "very popular and very prevalent" at the time he wrote, and that he therefore was cutting against the grain. Id at 51 . But even supporters of judicial review often suggested that courts should disregard laws on constitutional grounds only in "very clear case[s]." Hylton v United States, 3 US (3 Dall) 171, 173, 175 (1796) (Chase) (indicating that Congress's "deliberate decision" on a question of constitutional interpretation "would determine me, if the case was doubtful, to receive the construction of the legislature"). See also Sylvia Snowiss, Judicial Review and the Law of the Constitution 34-38 (Yale 1990) (claiming broadly that people of the day did not want judges to indulge in contestable interpretations of the Constitution, and that people either opposed judicial review or wanted judges to disregard only statutes that were plainly unconstitutional); Larry D. Kramer, Supreme Court 2000 Term Foreword: We the Court, 115 Harv L Rev 4, 74 (2001) (asserting that while "most of the Framers and Founders were not thinking about judicial review" one way or the other, those who had given early thought to its details generally believed that it would come into play "only when the unconstitutionality of a law was clear beyond dispute"). For people who took this view, courts would play little self-conscious role in selecting among possible interpretations of ambiguous constitutional provisions.

Other members of the founding generation favored a larger judicial role. In a 1793 opinion about state constitutional law, Judge Spencer Roane of Virginia emphasized that courts generally would be "perfectly disinterested" in addressing constitutional questions, while the legislature often would be biased because its own powers would be at issue. Kamper $v$ Hawkins, 3 Va (1 Va Cas) $* 20, * 38-39$ (1793). Only when the judges could not claim such disinterest - when they confronted cases involving either their "private interest" or "the powers of the judiciary"-did Roane urge courts to be especially careful, and "to distrust their own judgment if the matter is doubtful." Id. Debates in the First Congress confirm that at least some members of the founding generation expected courts to play a significant role in liquidating at least some of the Constitution's indeterminacies. See, for example, The Daily Advertiser (June 18, 1789), reprinted in Bickford, Bowling, and Veit, eds, 11 Documentary History of the First Congress 845, 849 (cited in note 24) (remarks of Rep William Smith on June 16,1789) (asserting that "[i]t was [the judiciary's] right to expound the constitution" on the contestable issue of the President's power to remove executive officers); Daily Advertiser (June 22, 1789) at 899 (cited in note 24) (remarks of Rep James Madison on June 17,1789) (acknowledging that "in the ordinary course of things, the exposition of the constitution devolves on the judiciary," though denying that the judiciary's power of exposition was exclusive).

39 Letter from Madison to Trist at 211 (cited in note 27).

40 See, for example, Stuart v Laird, 5 US (1 Cranch) 299, 309 (1803) (Paterson) (affirming that Congress can constitutionally provide for members of the Supreme Court to sit on circuit courts, and asserting that practice under the Judiciary Act of 1789 "has ... fixed the construction" of the Constitution on this point); Brutus XII, NY J (Feb 7, 1788), reprinted in John P. Kaminski and Gaspare J. Saladino, eds, 16 The Documentary History of the Ratification of the Constitution 
2. Eighteenth-century lexicography and the notion of "fixing" meaning.

Modern scholars know about the founders' references to "fixing" the Constitution's meaning," but they have not remarked upon the significance of this locution. In the eighteenth century, the notion of "fixing" meaning was a topic of considerable controversy, attracting attention from Jonathan Swift, Samuel Johnson, and other literary giants. It was the watchword of people who wanted the English language to be impervious to change-a project that may strike modern readers as silly, but that was seriously discussed at the time.

Efforts to "fix" the language seem to have taken root in France earlier than in England. In the 1630s, the French government officially recognized l'Académie Française, the "principal function" of which was "to labour with all the care and diligence possible to give exact rules to our language and to render it capable of treating the arts and sciences." compose a dictionary of the French language, in imitation of the Vocabolario that the Italian Accademia della Crusca had already produced. ${ }^{43}$ The ambition behind this project is reflected in the dedication of the dictionary that the French Academy eventually published in 1694. According to the Academy, "if there has ever been the promise that a living Language may come to be fixed, and no longer to depend on the caprice and the tyranny of Usage, we have reason to believe

72, 73 (State Historical Society of Wisconsin 1986) (assuming that principles used by the Supreme Court in deciding questions about "the meaning and construction of the constitution" will "become fixed, by a course of decisions"). See also Gulian C. Verplanck, Speech When in Committee of the Whole, in the Senate of New-York, on the Several Bills and Resolutions for the Amendment of the Law and the Reform of the Judiciary System 28 (Hoffman \& White 1839):

$[\mathrm{N}]$ o matter how clear you attempt to make the words of a provision, the interpretation of language, (if there be no external means of fixing that interpretation) furnishes a vast latitude to the Judge in applying the law to any state of facts. ... Look for instance at our own statute law and our constitutional law. How seldom is the sense undoubted, until usage and precedent have fixed it.

See also Billy v South Carolina, 11 SCL (2 Nott \& McCord) *356, *359-60 (Const Ct App 1820):

The [state] constitution is no more than a recognition of general principles; but they often require an explanation of their true import, which is to be found in judicial decisions, legislative expositions, and received practice. These explain and illustrate, and finally fix one precise understanding; without which, words are too variable, and general principles too easily perverted to be relied upon.

41 See, for example, Powell, 98 Harv L Rev at 910 (cited in note 12) (noting that in Federalist 78, Alexander Hamilton "steadfastly reiterated The Federalist's earlier claims that it was appropriate and necessary for the courts to 'liquidate and fix [the] meaning and operation' of laws, including the Constitution").

42 D. Maclaren Robertson, A History of the French Academy 12-13 (G.W. Dillingham 1910) (translating Article 24 of the rules promulgated for the Academy in February 1635).

43 See Robert L. Collison, A History of Foreign-Language Dictionaries 77, 79 (Andre Deutsch 1982). 
that ours has reached in our days to that glorious point of immutability." ${ }^{4}$

A number of English men of letters looked across the Channel with envy and urged their country to emulate the French Academy. Humphrey Wanley advocated publication of "[a] Dictionary for fixing the English Language, as the French and Italian." ${ }^{45}$ Daniel Defoe likewise expressed dismay at "all the Irregular Additions that Ignorance and Affectation have introduc'd" into written English, and he called for the creation of a learned society that would purify and regulate the language. Defoe hoped that once such a society was established, "no Author wou'd have the Impudence to Coin [new words] without their Authority," for "'twou'd be as Criminal then to Coin Words, as Money.",

Perhaps the most prominent proposal for "fixing" the English language was a pamphlet that Jonathan Swift published in 1712, in the form of a letter to the Earl of Oxford. Like other literary men of the day, Swift worried that "the perpetual Variations of our Speech" would prevent future generations from understanding and appreciating the works that he and his contemporaries were producing. ${ }^{47}$ Lan-

44 Robertson, History of the French Academy at 240 (cited in note 42).

451 Archaeologia: or, Miscellaneous Tracts, Relating to Antiquity xxxii (Society of Antiquaries of London 3d ed 1804) (quoting an unpublished manuscript that Wanley delivered to the Earl of Oxford). See also 18 The New Encyclopaedia Britannica 279 (15th ed 1998) (identifying 1707 as the date of this manuscript).

46 Daniel Defoe, An Essay upon Projects 91-92 (AMS 1999) (Joyce D. Kennedy, Michael Seidel, and Maximillian E. Novak, eds) (originally published 1697). Defoe indicated that lawyers should not be in his proposed society, for their English tended to be "full of Stiffness and Affectation, hard Words, and long unusual Coupling of Syllables and Sentences, which sound harsh and untuneable to the Ear, and shock the Reader both in Expression and Understanding." Id at 91.

Defoe was not the first prominent Englishman to worry about language change and to advocate a society for retarding or regulating it. Other seventeenth-century authors who had previously expressed similar views included the poets John Dryden and Lord Roscommon and the diarist John Evelyn. See Samuel Johnson, 1 Lives of the English Poets 164 (World's Classics ed 1933) (originally published 1779); Mark W. Catalano, Proposals for a Language Academy in England from 1617 to the Publication of Samuel Johnson's Dictionary 7-11 (1974) (unpublished M.A. thesis, University of Virginia).

47 Jonathan Swift, A Proposal for Correcting, Improving and Ascertaining the English Tongue; in a Letter to the Most Honourable Robert Earl of Oxford and Mortimer, Lord High Treasurer of Great Britain 32 (Scolar 1969) (originally published 1712) ("The Fame of our Writers is usually confined to these two Islands, and it is hard it should be limited in Time, as much as Place ...."). See also, for example, Alexander Pope, An Essay on Criticism (originally published 1711), in E. Audra and Aubrey Williams, eds, 1 The Poems of Alexander Pope: Pastoral Poetry and An Essay on Criticism 239, 293 (Methuen 1961) ("No longer now that Golden Age appears, / When Patriarch-Wits surviv'd a thousand Years; / Now Length of Fame (our second Life) is lost,/ And bare Threescore is all ev'n That can boast: / Our Sons their Fathers' failing Language see, / And such as Chaucer is, shall Dryden be."); Edmund Waller, Of English Verse (originally published 1668), in G. Thorn Drury, ed, 2 The Poems of Edmund Waller 69, 69-70 (Routledge 1893) ("But who can hope his lines should long / Last in a daily changing tongue? / . . Poets that lasting marble seek, / Must carve in Latin, or in Greek; / We write in sand; our language grows, / And, 
guage change, in Swift's view, artificially limited the incentives available to present-day authors, who knew that their works "will be read with Pleasure but a very few Years, and in an Age or two shall hardly be understood without an Interpreter." ${ }^{, 8}$ It also impeded the ability of future generations to draw upon the wisdom of the past. ${ }^{49}$ Swift therefore urged that "some Method should be thought on for ascertaining and fixing our Language for ever, after such Alterations are made in it as shall be thought requisite. For I am of Opinion, that it is better a Language should not be wholly perfect, than that it should be perpetually changing ...., ,

While Swift aspired "to fix [the English language] for ever,", he recognized that the development of knowledge would continue to make some new words necessary. He had no objection to enlarging the language in this way, although he wanted new words to be introduced only when existing words would not do. ${ }^{52}$ But Swift saw no reason why old words necessarily had to change or fall into disuse. If the meaning of the old words could be perpetuated, "then the old Books will yet be always valuable, according to their intrinsick Worth, and not thrown aside on account of unintelligible Words and Phrases, which appear harsh and uncouth, only because they are out of Fashion., ${ }^{, 53}$ To help achieve this goal, Swift called for the creation of a language society modeled on the French Academy, whose decisions would set a standard both for future authors and for future members of the society.

Swift's advocacy of ways to "fix" the English language attracted considerable attention. The proposal "was popular enough to require a second edition within a few months, and was reprinted throughout the eighteenth century in editions of Swift's Works, both small and large collections." 55 Of course, not all the attention was positive; John Oldmixon scoffed that "[t]he Doctor may as well set up a Society to

like the tide, our work o'erflows."); A.D. Horgan, Johnson on Language: An Introduction 94-95 (St. Martin's 1994) (noting these and other authors' "concern [ ] for the durability of the English language ...., lest the works of modern authors rapidly become unintelligible to succeeding generations").

48 Swift, Proposal at 42 (cited in note 47).

49 See id at 37 ("[T]he Glory of [Queen Anne's] Reign ... ought to be recorded in Words more durable than Brass, and such as our Posterity may read a thousand Years hence, with Pleasure as well as Admiration.").

so Id at 31 .

51 Id at 15.

52 See id at 34.

53 Id.

54 See id at 30-34 (suggesting that his proposed society could "receive whatever new [words] they shall find occasion for," as long as "no Word which [they] shall give a Sanction to, be afterwards antiquated and exploded").

55 Frontispiece, in Swift, Proposal (cited in note 47). 
find out the Grand Elixer ... as to fix our Language beyond their own Times.,"s6 But Swift's proposal was certainly well known, and there were many who thought it feasible. According to one modern historian, "fantasies of 'fixing' the language [ ] dominated much of eighteenth-century lexicography.",

For a time, Samuel Johnson - who would become the century's leading lexicographer - may have shared the belief that English could be "fixed." In his 1747 plan for an English dictionary, Johnson indicated that "one great end of this undertaking is to fix the English language." ${ }^{88}$ But whatever Johnson may have thought at the outset of his project, he ultimately concluded that change could not be fully arrested. "Those who have been persuaded to think well of my design," he wrote in the 1755 preface to his dictionary,

require that it should fix our language, and put a stop to those alterations which time and chance have hitherto been suffered to make in it without opposition. With this consequence I will confess that I flattered myself for a while; but now begin to fear that I have indulged expectation which neither reason nor experience can justify.

As Johnson observed, there was no known example of "a nation that has preserved their words and phrases from mutability." Johnson plainly did not like language change, he suggested that it could only be slowed down, not avoided altogether. He hoped that his dictionary would help to serve this purpose: "[I]t remains that we retard what we cannot repel.",61

Americans of the founding generation were well aware of the concept of "fixing" the language and of the attention that this issue

56 John Oldmixon, Reflections on Dr. Swift's Letter to the Earl of Oxford, About the English Tongue 25 (Augustan 1948) (originally published 1712).

57 Jonathon Green, Chasing the Sun: Dictionary-Makers and the Dictionaries They Made 161 (Jonathan Cape 1996).

58 Samuel Johnson, The Plan of a Dictionary 11 (Scolar 1970) (originally published 1747).

59 Samuel Johnson, 1 A Dictionary of the English Language (W. Strahan 1755) (unpaginated, *9).

60 Id.

61 Id (unpaginated, *10). Johnson would later assert that Swift's 1712 proposal for fixing the English language was "written without much knowledge of the general nature of language, and without any accurate enquiry into the history of other tongues." According to Johnson, the notion that "certainty and stability" could be attained was "contrary to all experience." Samuel Johnson, 2 Lives of the English Poets 200-01 (World's Classics ed 1936) (originally published 1781). See also Johnson, 1 Lives at 164 (cited in note 46) ("The French academy thought that they refined their language, and doubtless thought rightly; but the event has not shewn that they fixed it; for the French of the present time is very different from that of the last century."); id at 164-65 (conceding that as a result of the efforts of the Accademia della Crusca, the Italian language "was ... so fixed that it has changed but little," but arguing that this success could not be replicated in England). 
had received in eighteenth-century Europe. According to an 1801 article in a Philadelphia newspaper, "[Swift's] letter to Lord Oxford is familiar to every person." ${ }^{, 62}$ Not surprisingly, then, American writers who mentioned Swift's pamphlet tended to assume that their readers already knew about it. ${ }^{63}$

The fact that Swift's pamphlet was so well known does not mean that its message was widely accepted. To the contrary, Americans of the founding generation tended to agree with Dr. Johnson that language change was inevitable. ${ }^{44}$ Some, like Thomas Jefferson, were unconcerned by this fact: Jefferson proclaimed himself a "zealous [friend] to ... Neology,", and he scoffed at "the preposterous idea of fixing the language." "Others, like James Madison, were more sympathetic to the goal of "fixing" the meaning of words, but viewed it as an "unattainable" ideal. As Madison told one correspondent, "[a]11 languages ... are liable to changes," and some of the causes of those changes are "inseparable from the nature of man and the progress of society." ${ }^{167}$ Whatever their position on this issue, though, Americans

62 Philology, 1 The Port Folio 42 (Feb 7, 1801). For pointing me to this article, I am indebted to Allen Walker Read, American Projects for an Academy to Regulate Speech, in Percy Waldron Long, ed, 51 Publications of the Modern Language Association of America 1141, 1149 n 30 (1936).

63 See, for example, Royall Tyler, The Yankey in London 175-77 (Riley 1809) (referring to, and criticizing, "[Swift's] celebrated letter to Lord Oxford"), quoted in Read, American Projects at 1150 (cited in note 62); Letter from William S. Cardell to Thomas B. Robertson (Oct 12,1821), in American Academy of Language \& Belles Lettres, Circular No. III; to the American Members, and Patrons of the Institution, from the Corresponding Secretary 27, 31 (Baldwin 1822) (suggesting agreement with Swift's bottom line, but asserting that "his letter to Lord Oxford in favor of an English National Academy, is not equal in talent to most of his other productions").

64 At least in later years, even people who sympathized with Swift acknowledged this dominant attitude. See, for example, Letter from Cardell to Robertson at 31 (cited in note 63) ("The dogmas of Doctor Johnson, so often quoted, are entitled to less credit than is commonly attached to them."). But see William S. Cardell, Essay on Language, as Connected with the Faculties of the Mind, and as Applied to Things in Nature and Art 29-30 (Wiley 1825) (suggesting that "to a considerable extent" Americans believe that the English language "is already fixed, and can admit no change"), quoted in Read, American Projects at 1163 n 72 (cited in note 62).

65 Letter from Thomas Jefferson to John Waldo (Aug 16, 1813), in Andrew A. Lipscomb, ed, 13 The Writings of Thomas Jefferson 338, 340 (Jefferson Memorial Association 1905).

66 Letter from Thomas Jefferson to Joseph Milligan (Apr 6, 1816), in Andrew A. Lipscomb, ed, 14 The Writings of Thomas Jefferson 456, 463 (Jefferson Memorial Association 1905). See also Letter from Thomas Jefferson to William S. Cardell (Jan 27, 1821), in American Academy of Language \& Belles Lettres, Circular No. III at 10 (cited in note 63):

If, like the French Academicians, it were proposed to fix our language, it would be fortunate, that the step was not taken in the days of our Saxon ancestors whose vocabulary would illy express the science of this day. Judicious neology can alone give strength and copiousness to language, and enable it to be the vehicle of new ideas.

67 Letter from James Madison to Converse Sherman (Mar 10,1826), in 3 Letters of Madison 518,519 (cited in note 27 ). 
certainly were familiar with the idea of "fixing" the language, and they associated this concept with permanence and immutability.

The founders' repeated references to "fixing" the meaning of the Constitution must be understood in this context. When Madison stressed that "the meaning of a Constitution should be fixed and known," or when he declared that precedents can "fix" the meaning of laws that started off being open to a range of possible interpretations, ${ }^{70}$ his words resonated with the lexicographical jargon of the day. Although Madison conceded that the words used in the Constitution might well fall out of favor or acquire new shades of meaning in later usage, he was suggesting that their meaning in the Constitution would not change; once that meaning was "fixed," it should endure." Thus, Madison rejected what T. Alexander Aleinikoff calls "present-minded" interpretation - the notion that courts seeking to construe old statutes (and, presumably, constitutions) should proceed "as if the statute had been recently enacted" and ask themselves "what is the most plausible meaning today that these words will bear." Although Madison believed in the inevitability of linguistic change, he did not think that this change should affect the meaning of laws or constitutions.

In an 1826 letter, Madison explicitly discussed the interplay between his lexicographical views and his views of legal interpretation. A correspondent named Converse Sherman had sent Madison a copy of Noah Webster's prospectus for a dictionary, and Madison responded with his thoughts about the utility of such works. Madison began by stressing the desirability of "a standard work, explaining, and as far as possible fixing, the meaning of words and phrases." He conceded that "compleat success" in the project of fixing language was impossible; there was no "perfect remedy" for the "evil" of linguistic change. But it was still worthwhile to "record[] with admitted fidelity the state of a language at the epoch of the record," in part because such records

68 Compare Noah Webster, Dissertations on the English Language 25 (Scolar 1967) (originally published 1789) ("[A]n attempt to fix a standard on the practice of any particular class of people is highly absurd: As a friend of mine once observed, it is like fixing a light house on a floating island. It is an attempt to fix that which is in itself variable ....").

69 Letter from Madison to Ingersoll at 184 (cited in note 37).

70 See note 39 and accompanying text. See also note 40 (providing other examples of this usage).

71 See Simon Winchester, The Professor and the Madman: A Tale of Murder, Insanity, and the Making of the Oxford English Dictionary 91 (Harper Collins 1998) (noting that "fixing has been a term of lexicographical jargon" ever since the days of Defoe and Dryden).

72 Compare Joseph Story, Law, Legislation, and Codes, in Francis Lieber, ed, 7 Encyclopedia Americana 576 (Desilver, Thomas 1831) ("The sense of a law once fixed by judicial interpretation, is for ever deemed its true and only sense."), reprinted in James McClellan, Joseph Story and the American Constitution: A Study in Political and Legal Thought 350, 360 (Oklahoma 1971).

73 T. Alexander Aleinikoff, Updating Statutory Interpretation, 87 Mich L Rev 20, 59-60 (1988) (emphasis omitted). 
would help future generations understand the true meaning of the epoch's laws. "In the exposition of laws, and even of Constitutions," he exclaimed, "how many important errors may be produced by mere innovations in the use of words and phrases, if not controulable by a recurrence to the original and authentic meaning attached to them!" "74 Other letters from Madison reflect the same view: "The change which the meaning of words inadvertently undergoes" is a source of "misconstructions of the Constitutional text,", and it would be "preposterous" to let "the effect of time in changing the meaning of words and phrases" justify "new constructions" of written constitutions and laws.

3. Lessons from the interpretation of other legal documents.

Madison's emphasis on the Constitution's "original and authentic meaning" reflected well-established rules for the interpretation of other sorts of legal documents. Emmerich de Vattel, whose 1758 treatise on the law of nations enjoyed canonical status among Americans of the founding generation, ${ }^{77}$ had discussed precisely the same issue in connection with the interpretation of treaties and written contracts. After stressing the strong presumption that an instrument's words have "the sense given them in ordinary use," Vattel made clear that "[t]he use to which we refer is that of the period at which the treaty or other deed was entered into and its terms drawn up." Because "[1] anguages are constantly varying in form" and "the force and meaning of terms change in the course of time," this principle necessitated research: "When we have to interpret a very old treaty we must know the common use of the terms at the time the treaty was drawn up, and we can discover what that use was from deeds of the same period and from contemporary writers, by a careful process of comparison." ${ }^{, 78}$

The same principle governed the interpretation of statutes. As Thomas Rutherforth put it in his influential discussion of the universal principles of interpretation, "[l]aws operate at a distance of time," and

74 Letter from Madison to Sherman at 519 (cited in note 67).

75 Letter from James Madison to N.P. Trist (Mar 2, 1827), in 3 Letters of Madison 565, 565 (cited in note 27). See also Letter from Madison to Ingersoll at 185-86 (cited in note 37) (asserting that if practice did not fix the interpretation of laws and constitutions, "the danger of error" about their true meaning "must increase with the increasing oblivion of explanatory circumstances, and with the continual changes in the import of words and phrases").

76 Letter from James Madison to Professor Davis (1833, unsent), in 4 Letters of Madison 232,249 (cited in note 27).

77 See, for example, Peter Onuf and Nicholas Onuf, Federal Union, Modern World: The Law of Nations in an Age of Revolutions, 1776-1814 11 (Madison House 1993) (reporting that Vattel's treatise "was unrivaled among such treatises in its influence on the American founders").

78 Emmerich de Vattel, The Law of Nations 202 (Carnegie Institution 1916) (Charles G. Fenwick, trans) (originally published 1758). 
people "who live many years[] after the laws were made" may therefore face some difficulties in ascertaining "their true meaning." To deal with this predicament, Rutherforth observed that people can "look[] back into ... the contemporary practice ..., which the law produced in the first instance," in order to "see in what sense it was then understood"; this approach "will be a means of removing any doubts about the sense of it, which are owing only to our remoteness from its original establishment.",

Madison's own rhetoric suggests the ubiquity of the principle that statutory language should be understood according to its original meaning rather than its current meaning. "What a metamorphosis would be produced in the code of law," he once observed, "if all its ancient phraseology were to be taken in its modern sense!",

Language change was less likely to be an issue for interpreters of wills than for interpreters of treaties or statutes, because fewer years were likely to pass between the time a will was written and the time it needed to be interpreted. Even in this shorter span, though, other circumstances might change in ways that obscured the testator's original meaning. Again, lawyers acknowledged that they should seek to recapture and enforce that original meaning. As the distinguished Maryland attorney William Paca ${ }^{81}$ observed shortly before Independence, "[e]very will in the construction of it, is to be considered as at the time of the making of it."

In light of the accepted approach to the interpretation of other sorts of legal documents, we should not be surprised that leading antebellum treatises about the Constitution echoed Madison's empha-

79 Thomas Rutherforth, 2 Institutes of Natural Law 336-37 (Bentham 2d ed 1756). See also William Blackstone, 1 Commentaries on the Laws of England 59 (Chicago 1979) (originally published 1765) (taking for granted that in interpreting statutes, the relevant legislative intent is that which existed "at the time when the law was made"); Mercer $v$ Commonwealth, 4 Va (2 Va Cas) *144, *146 (Gen Ct 1818) ("[A]lthough the Penitentiary Laws have mitigated the punishment of this offence, yet the Statute ought now to receive such construction as it would have received at the time of its passage ....").

80 Letter from James Madison to Henry Lee (June 25, 1824), in 3 Letters of Madison 441, 442 (cited in note 27). See also Letter from Madison to Davis at 249 (cited in note 76) ("What inroads would be made in a code if the ancient statutes were to be read through the modern meaning of their phraseology?").

81 In the early 1770 s, Paca was one of "the most eminent counsel then at the bar." Chew's Lessee $v$ Weems, $1 \mathrm{H} \& \mathrm{McH} 463,464-65$ (Md Prov 1772) (reporter's note). He would go on to sign the Declaration of Independence, to serve as chief judge of Maryland's General Court (and later governor of the state), to participate in Maryland's ratifying convention, and to accept an appointment to the federal bench from President Washington. See Biographical Directory of the Federal Judiciary, 1789-2000 698 (Bernan 2001); John P. Kaminski and Gaspare J. Saladino, eds, 13 The Documentary History of the Ratification of the Constitution 453 n 15 (State Historical Society of Wisconsin 1981).

82 Chew's Lessee, $1 \mathrm{H} \& \mathrm{McH}$ at 472 (argument of counsel). Accord, for example, Lessee of Caldwell v Ferguson, 2 Yeates 380, 380 (Pa 1798) (McKean) ("The construction of a will must have relation to the time of making the same, and not the time of the death of the testator."). 
sis on the document's original meaning. Nathaniel Chipman's Principles of Government observed that "the meaning of words or terms" often changes over time, but that when this happened "the meaning of the constitution is not therefore changed." Joseph Story's Commentaries on the Constitution agreed that the Constitution "is to have a fixed, uniform, permanent construction," and that "so far ... as human infirmity will allow," it "should be ... the same yesterday, to-day, and for ever." ${ }^{84}$

To judge from Madison's writings, there were two ways for the Constitution's meaning to be "fixed." In many respects, the document's meaning was fixed from the very beginning; its provisions had an "original and authentic meaning,", from which subsequent interpretation could not properly depart. ${ }^{86}$ In other respects, the Constitution was ambiguous; its provisions lent themselves to a range of permissible interpretations. Even within that range, however, modern commentators are wrong to suggest that Madison envisioned "constant reinterpretation" of the Constitution. ${ }^{87}$ Far from expecting the Constitution to have a continuously evolving meaning, Madison looked forward to the day when the document's "meaning on all great points" would be "settled by precedents." eralist 37 about the inevitable obscurity of written laws were restricted to new laws, whose meaning had not yet been settled by practice.

83 Nathaniel Chipman, Principles of Government; a Treatise on Free Institutions 254 (Edward Smith 1833).

84 Joseph Story, 1 Commentaries on the Constitution of the United States $\$ 426$ at 410 (Hilliard, Gray 1833).

85 See note 74 and accompanying text.

86 See, for example, Letter from Madison to Trist at 211 (cited in note 27) (denying that precedents could legitimately "alter" the Constitution, except in the sense of selecting from within the range of permissible interpretations). See also Caleb Nelson, Stare Decisis and Demonstrably Erroneous Precedents, 87 Va L Rev 1, 10-14 (2001) (discussing Madison's views on this issue); id at 14-21 (tracking support for Madison's views in antebellum cases about statutory and constitutional interpretation).

87 See Robert A. Ferguson, Law and Letters in American Culture 21-22 (Harvard 1984). See also Garry Wills, Explaining America: The Federalist 54 (Doubleday 1981) (taking Madison to support not only "broad construction" but also "the idea of the Constitution as a living document' responding to society's needs, not as a text frozen in the first approximations of those who compromised it into being").

88 Letter from Madison to Johnston at 250 (cited in note 31).

89 See text accompanying note 30 . Even with respect to new laws, Madison thought that draftsmen could often minimize the obscurity of their handiwork by avoiding "new terms," which were "always liable, more or less, ... to discordant interpretations" until they had been "made technical by practice." Letter from James Madison to Thomas S. Grimke (Jan 15, 1828), in 3 Letters of Madison 611, 611 (cited in note 27). As a model for people trying to draft statutory codes, Madison held up the work of a committee to which the Virginia legislature had entrusted a codification project in 1776; Madison praised the committee, which Thomas Jefferson had led, for "invariably prefer[ring] technical terms and phrases having a settled meaning where they are applicable." Id at 612. See also Letter from James Madison to Samuel H. Smith (Nov 4, 1826), in 3 Letters of Madison 531, 532 (cited in note 27) (calling the committee's work "a model ... of statu- 
Similarly, while he conceded that "the exposition of the Constitution" was a "copious source" of difficulties for the First Congress, he observed that "[t]hose who may follow will have an easier task." Once precedents had settled upon a meaning within the range of permissible interpretations, Madison expected that meaning to be "fixed" for the future.

\section{B. An Objection}

The notion that Madison and others envisioned a Constitution with a "fixed" meaning-a meaning that, in the absence of amendment, is invariant over time-invites at least one obvious objection. The founders were smart people, and they knew that their young na-

tory composition, containing not a single superfluous word, and preferring always words or phrases of a meaning fixed as much as possible by oracular treatises or solemn adjudications").

Jefferson himself had previously expressed a similar view of the committee's work. In an 1809 letter, he recalled that his committee had tried not to change the language of certain "ancient statutes," in part because "the meaning of every word [had been] so well settled by decisions, as to make it safest not to change words where the sense was to be retained." Letter from Thomas Jefferson to Skelton Jones (July 28, 1809), in Andrew A. Lipscomb, ed, 12 The Writings of Thomas Jefferson 297, 299 (Jefferson Memorial Association 1905). Jefferson also recalled that the committee had decided not to try to reduce the entire common law to statutory provisions, since "every word and phrase in [the new statutes] would become a new subject of criticism and litigation, until its sense should have been settled by numerous decisions." Id. See also Thomas Jefferson, Autobiography (1821), in Andrew A. Lipscomb, ed, 1 The Writings of Thomas Jefferson 1, 62-63 (Jefferson Memorial Association 1905) (noting that when Edmund Pendleton and Thomas Lee had proposed "to abolish the whole existing system of laws, and prepare a new and complete Institute," the other members of the committee had objected that:

every word of that text, from the imperfection of human language, and its incompetence to express distinctly every shade of idea, would become a subject of question and chicanery, until settled by repeated adjudications; and this would involve us for ages in litigation, and render property uncertain, until, like the statutes of old, every word had been tried and settled by numerous decisions, and by new volumes of reports and commentaries.

90 Letter from Madison to Johnston at 250 (cited in note 31).

91 Letter from James Madison to James Madison, Sr. (July 5, 1789), in Hobson and Rutland, eds, 12 Papers of Madison 278, 278 (cited in note 31). See also Letter from James Madison to Edmund Randolph (May 31, 1789), in Hobson and Rutland, eds, 12 Papers of Madison 189, 190 (cited in note 31) (reporting that "[s]carcely a day passes [in the First Congress] without some striking evidence of the delays and perplexities springing merely from the want of precedents," but that "[t]ime will be a full remedy for this evil"); Letter from Madison to Johnston at 250 (cited in note 31) ("After the first essays the work will become every day more easy."); Letter from Samuel Johnston to James Madison (July 8,1789), in Hobson and Rutland, eds, 12 Papers of Madison 284, 285 (cited in note 31) ("I can easily conceive that you will at first meet with a great many perplexities in your progress of carrying the Constitution into effect, but these will gradually lessen as you proceed, and Precedents once formed on solid principles will prevent difficulties from recurring on the same points.").

Madison returned to this theme in later correspondence. Writing in 1830 , for instance, he expressed no surprise " $[t]$ hat ... there should be occasional difficulties and differences in the practical expositions" of "a Constitution so new and so complicated," but he indicated that such disputes would diminish as "a course of practice of sufficient uniformity and duration to carry with it the public sanction shall settle doubtful or contested meanings." Letter from James Madison to M.L. Hurlburt (May 1830), in 4 Letters of Madison 73, 74 (cited in note 27). 
tion was likely to undergo enormous changes in the years to come." Given this awareness, would they not have been skeptical of calls for perpetual recourse to the "original and authentic meaning" of the Constitution? Would they not have thought that a Constitution whose meaning was "fixed" in this way would lack the flexibility necessary to accommodate America's inevitable changes?

Members of the founding generation were no strangers to the issues raised by laws that extended indefinitely into the future. In the First Congress, Madison argued at length that the Impost Act should contain a sunset provision, so that it would remain law only if future Congresses decided to reenact it; in his view, "a revenue law unlimitted in its duration" offended "the principles of republicanism." "When some of his colleagues responded that future Congresses could repeal or amend the law even if it did not expire automatically, Elbridge Gerry countered that the President and a minority of the Senate could block such efforts, leaving the people's "immediate representatives" in the House unable to change an unpopular course set by their prede-

92 See, for example, Federalist 14 (Madison), in The Federalist 83, 87 (cited in note 26) (predicting improvements in transportation that would link the different parts of the nation closer together and make communication between them "more and more easy"); Federalist 55 (Madison), in The Federalist 372, 375 (cited in note 26) (predicting dramatic and sustained increases in the nation's population); Federalist 11 (Hamilton), in The Federalist 65, 69 (cited in note 26) (looking forward to "[a]n active commerce, an extensive navigation, and a flourishing marine"); Debates of the New York Convention (June 27, 1788), in Jonathan Elliot, ed, 2 The Debates in the Several State Conventions on the Adoption of the Federal Constitution 332, 341 (US Congress 2d ed 1836) (reporting Chancellor Robert R. Livingston's suggestion, at the New York ratifying convention, that America's economy would come to be dominated by manufacturing). See also Debates of the Massachusetts Convention (Jan 31, 1788), in Kaminski and Saladino, eds, 6 Documentary History of the Ratification 1373, 1377 (cited in note 24) (reporting General Heath's observation that the system of government being erected was not just for "the present people of the United States," but also "for all those States which may hereafter rise into existence within the jurisdiction of the United States - and for millions of people yet unborn"); Federalist 55 at 376 (predicting changes whose nature could not yet be predicted). See generally Hamburger, 88 Mich L Rev at 254-58 (cited in note 24) (describing the founding generation's awareness of "the theories of Hale and the Scots that society undergoes change-change that requires or causes a corresponding development of legal and governmental institutions").

93 See, for example, Stephen R. Munzer and James W. Nickel, Does the Constitution Mean What It Always Meant?, 77 Colum L Rev 1029, 1032 (1977) ("[A] constitutional system that makes formal amendments very difficult and does not allow for gradual change through interpretation is likely to become rigid and out-of-date.").

94 Gazette of the United States (May 20, 1789), reprinted in Charlene Bangs Bickford, Kenneth R. Bowling, and Helen E. Veit, eds, 10 Documentary History of the First Federal Congress of the United States of America 676,676 (Johns Hopkins 1992).

95 See id at 678 (remarks of Rep Fisher Ames) (arguing that "as the act may be repealed or amended, as experience may direct, there seems to be no good reason for limiting its existence"); Lloyd's Notes (May 15, 1789), in Bickford, Browning, and Veit, eds, 10 Documentary History of the First Congress 670, 674 (cited in note 94) (similar remarks of Rep Elias Boudinot); The Congressional Register (May 15, 1789), reprinted in Bickford, Browning, and Veit, eds, 10 Documentary History of the First Congress 679, 681 (cited in note 94) (similar remarks of Rep Thomas Sinnickson). 
cessors. ${ }^{96}$ On the strength of such arguments, Madison's motion to add a sunset provision carried by a vote of 41 to $8 .^{77}$ Indeed, Thomas Tudor Tucker of South Carolina thought that almost all statutes should include such provisions: "Nothing ... could justify [a perpetual law] but the necessity, simplicity, and the immutability of the object, and the immutability of the circumstances which related to it[-]circumstances which would render a law equally necessary now, and on all future occasions.","

In one specific context, concern about unduly long-lived laws found its way into the Constitution itself. Article I empowers Congress "[t]o raise and support Armies," but adds that "no Appropriation of Money to that Use shall be for a longer Term than two Years." mandating sunset provisions for this one class of statutes, the Constitution ensured that no standing army could be maintained without an affirmative decision by each new Congress; a Congress that happened to favor standing armies could not use the power of inertia to impose its decision on the future. ${ }^{100}$

In other contexts, the framers chose not to require sunset provisions; they relied instead on future Congresses to repeal statutes that did not expire automatically but that had outlived their usefulness. Still, the very principle that such repeals are possible - that later statutes trump earlier ones - is itself an antidote to the "dead hand" problems that might otherwise result. Even if the current Congress purported to insulate a statute from any future modification or repeal, this provision would be ineffective, for it could itself be repealed; one Congress cannot bind its successors in this way. ${ }^{101}$ Members of the founding generation recognized and celebrated this principle. ${ }^{102}$

96 See Congressional Register (May 15, 1789) at 686 (cited in note 95).

97 See The New-York Daily Gazette (May 18,1789), reprinted in Bickford, Bowling, and Veit, eds, 10 Documentary History of the First Congress 701, 702 (cited in note 94).

98 The Daily Advertiser (May 18, 1789), reprinted in Bickford, Bowling, and Veit, eds, 10 Documentary History of the First Congress 693, 698 (cited in note 94).

99 US Const Art I, § 8, cl 12.

100 See Federalist 26 (Hamilton), in The Federalist 164, 168 (cited in note 26) ("The Legislature of the United States will be obliged by this provision, once at least in every two years, to deliberate upon the propriety of keeping a military force on foot; to come to a new resolution on the point; and to declare their sense of the matter, by a formal vote in the face of their constituents.").

101 See, for example, Blackstone, 1 Commentaries at $89-90$ (cited in note 79) (noting that "an old statute gives place to a new one," and "[a]cts of parliament derogatory from the power of subsequent parliaments bind not"). Compare United States $v$ Winstar Corp, 518 US 839, 872-76 (1996) (plurality) (qualifying this principle by noting that "the National Government has some capacity to make agreements binding future Congresses by creating vested rights").

102 See, for example, Congressional Register (May 15, 1789) at 685 (cited in note 95) (remarks of Rep Theodorick Bland) ("Can any person, who has read our Constitution, believe that it is in our power to pass a law without limitation? no, it is impossible. Every person knows that a future Congress may repeal this, and every other law we shall pass, as much as they think 
Their awareness of the "dead hand" problem, though, did not lead most members of the founding generation to conclude that the Constitution's meaning should continually be subject to reinterpretation. Instead, it affected what the framers chose to put into the Constitution in the first place. Except for a few provisions that were seen as temporary expedients (and that therefore were drafted to expire of their own force), ${ }^{103}$ the Constitution was seen as the home of "permanent" rules, cast in terms that "would not need to be adapted flexibly to circumstances." "[r]ules that had to be mutable" were not thought to belong in the Constitution. ${ }^{105}$

Professor Hamburger's evidence establishes that both Federalists and Anti-Federalists distinguished rules whose formulation would need to change with the circumstances (and that therefore were relegated to the domain of ordinary law) from rules that were "immutable" (and that therefore were eligible for inclusion in the Constitution) ${ }^{106}$ During the ratification debates, indeed, supporters of the Constitution repeatedly used this distinction to explain why certain provisions were or were not in the Constitution. When Anti-Federalists criticized the proposed Constitution for giving Congress power over the times, places, and manner of elections for the House of Representatives, ${ }^{107}$ James Madison responded that there was no better alternative: A matter so vital to the federal government's survival could not be left within the exclusive control of the states, and specific electoral regulations could not be "fixed in the Constitution" because they would need to be "adjust[ed] ... to the changes of circumstances."

proper."). See also The Congressional Register (May 16, 1789), reprinted in Bickford, Browning, and Veit, eds, 10 Documentary History of the First Congress 704, 712 (cited in note 94) (remarks of Rep Elias Boudinot) (agreeing that "it was not in the power of the legislature" to pass a law that could never be repealed or altered, though not necessarily tracing this principle to the Constitution). Contrast Eric A. Posner and Adrian Vermeule, Legislative Entrenchment: A Reappraisal, 111 Yale L J 1665 (2002) (questioning the basis of this principle), with John O. McGinnis and Michael B. Rappaport, Symmetric Entrenchment: A Constitutional and Normative Theory, 89 Va L Rev (forthcoming 2003) (presenting both historical and normative arguments against the power of Congress to pass unrepealable statutes).

103 See, for example, US Const Art I, $\$ 9$, cl 1 (providing that Congress could not prohibit the importation of slaves "prior to the Year one thousand eight hundred and eight"); US Const Art I, $\S 2, \mathrm{cl} 3$ (requiring a census to be taken "within three Years after the first Meeting of the Congress ... and within every subsequent Term of ten Years," but setting an initial apportionment of seats in the House of Representatives that would apply "until such enumeration shall be made").

104 Hamburger, 88 Mich L Rev at 287 (cited in note 24).

105 Id at 275.

106 See id at 265-300.

107 See, for example, Debates of the Virginia Convention (June 14, 1788), in Kaminski and Saladino, eds, 10 Documentary History of the Ratification 1258, 1290-91 (cited in note 24) (reporting George Mason's complaints about US Const Art I, § 4, cl 1).

108 Id at 1295. See Hamburger, 88 Mich L Rev at 289-90 (cited in note 24). See also Debates 
When Anti-Federalists warned that the ability of both federal and state governments to tax the same objects would produce "a constant jarring of claims and interests, ${ }^{, 109}$ Alexander Hamilton predicted that a "division of objects" would arise, with the federal government taxing some things and the states taxing others; he added, however, that "it would be absurd to fix [this division] in the Constitution," in part because "alteration of circumstances must render a change of the division indispensable." When Anti-Federalists complained that the Constitution did not "declare[] the common law of England to be in force,"111 Edmund Randolph retorted that the common law's rules "ought not to be immutably fixed" but instead should remain eligible to "be changed as circumstances may require."112

In sum, the framers were aware of the dead-hand problem, but they seem to have thought of it as a drafting issue rather than an interpretive issue. They proposed to solve the problem not by inviting future generations to read new meanings into the Constitution, but rather by writing a Constitution whose permanent and fixed meaning would be "calculated for all circumstances." "13

Of course, members of the founding generation certainly expected some of the Constitution's rules to have different applications in different contexts. This concept, indeed, was central to one of the

of the Virginia Convention (June 14, 1788) at 1262 (cited in note 107) (remarks of James Madison) (acknowledging that it would have been good, "if practicable," for the Constitution to prescribe the compensation of members of Congress, but arguing that an appropriate level of compensation could not be "ascertain[ed] [ ] immutably"); Debates of the Virginia Convention (June 20, 1788), in Kaminski and Saladino, eds, 10 Documentary History of the Ratification 1412, 1426 (cited in note 24) (remarks of Edmund Pendleton) (explaining that if the Constitution had "fix[ed] the number" of lower federal courts, "there it would remain, nor could it be increased or diminished as circumstances would render it necessary").

109 Debates of the New York Convention (June 27, 1788) at 333 (cited in note 92) (remarks of Melancton Smith).

110 Debates of the New York Convention (June 28, 1788), in Elliot, ed, 2 Debates 356, 364 (cited in note 92). See Hamburger, 88 Mich L Rev at 291 n 191 (cited in note 24).

111 Debates of the Virginia Convention (June 16, 1788), in Kaminski and Saladino, eds, 10 Documentary History of the Ratification 1299, 1330 (cited in note 24) (remarks of Patrick Henry).

112 Debates of the Virginia Convention (June 17, 1788), in Kaminski and Saladino, eds, 10 Documentary History of the Ratification 1338,1352-53 (cited in note 24). George Nicholas made the same argument as Randolph. See Debates of the Virginia Convention (June 16,1788) at 1333 (cited in note 111); Hamburger, 88 Mich L Rev at 241 (cited in note 24).

113 Debates of the New York Convention (June 27, 1788) at 343 (cited in note 92) (remarks of Chancellor Livingston). See also, for example, Debates of the Virginia Convention (June 11, 1788), in Kaminski and Saladino, eds, 9 Documentary History of the Ratification 1142, 1147 (cited in note 24) (remarks of James Madison) ("[A]s I hope we are considering a Government for a perpetual duration, we ought to provide for every future contingency."); Debates of the Virginia Convention (June 12,1788), in Kaminski and Saladino, eds, 10 Documentary History of the Ratification 1184, 1206 (cited in note 24) (remarks of James Madison) ("[W]hen we are preparing a Government for perpetuity, we ought to found it on permanent principles and not on those of a temporary nature."). 
framers' strategies for producing a document "calculated for all circumstances." In drafting rules for inclusion in the Constitution, the framers deliberately sought to use language that was general enough to accommodate relevant future changes."

For an obvious example, one need look no further than the Necessary and Proper Clause of Article I. When Anti-Federalists attacked this provision for giving Congress too much power, Madison responded that the Clause needed to apply "not only to the existing state of things, but to all the possible changes which futurity may produce." ${ }^{.15}$ Even if the framers could have specifically listed all the powers that were necessary and proper in 1787 for carrying the federal government's enumerated powers into effect, powers that were not on the list might become necessary later, while powers that were on the list might cease to be needed. ${ }^{116}$ The framers handled the possibility of such changes by establishing a formula - the "necessary and proper" rule-that incorporated current conditions as relevant variables. Within the category of powers that such general language was thought capable of conferring, ${ }^{117}$ the powers covered by the Necessary and Proper Clause were said to have a "fluctuating character": they "exist[ed], or not, according to extraneous circumstances."118

Other constitutional provisions may be ambiguous about whether they have the same "fluctuating character." To use the example that has drawn the most comment, consider the Eighth Amendment's ban on "cruel and unusual punishments." Members of the founding generation recognized some indeterminacy in this phrase from the start."

114 See, for example, Debates of the New York Convention (June 28, 1788) at 364 (cited in note 110) (remarks of Alexander Hamilton) ("Constitutions should consist only of general provisions: the reason is, that they must necessarily be permanent, and that they cannot calculate for the possible change of things."). See generally Hamburger, 88 Mich L Rev at 319-25 (cited in note 24) (discussing how the framers sought to avoid "obsolescence" by using language that was general but not indeterminate).

115 Federalist 44 (Madison), in The Federalist 299, 304 (cited in note 26).

116 Compare $M^{\prime}$ Culloch, 17 US (4 Wheat) at 331-33 (argument of Joseph Hopkinson) (contending that even if the Necessary and Proper Clause had authorized Congress to charter the first Bank of the United States in 1791, the proliferation of other banks since then meant that a national bank was no longer necessary, and Congress therefore lacked the power to charter the second Bank of the United States).

117 See id at 411 (referring to a category of "great substantive and independent power[s]" that "cannot be implied as incidental to other powers"); Alexander Hamilton, Opinion on the Constitutionality of an Act to Establish a Bank (Feb 23, 1791), in Harold C. Syrett, ed, 8 The Papers of Alexander Hamilton 63, 119 (Columbia 1965) (drawing a similar distinction between powers that are "independent \& substantive" and those that are "incidental \& auxiliary"). See also text accompanying notes 220-21 (quoting James Madison's admonitions against reading "great and important power[s]" into the Necessary and Proper Clause); Nelson, 115 Harv L Rev at 1639-43 (cited in note 8) (discussing this concept).

118 M'Culloch, 17 US (4 Wheat) at 331 (argument of Joseph Hopkinson).

119 During the campaign for ratification of the original Constitution, James Iredell fended off demands for a bill of rights by asserting that a prohibition on "cruel and unusual" punish- 
With the passage of time, however, present-day interpreters have had to face some additional questions about the Amendment's original meaning. Take the word "unusual." As used in the Amendment, does it refer forever afterward to punishments that were unusual in 1791, or instead to punishments that are unusual at the time they are being inflicted? ${ }^{120}$ The word "cruel" might raise similar questions; if the Amendment uses it in a relative sense (so that a punishment is "cruel" if it inflicts substantially more pain or humiliation than society customarily tolerates), interpreters again must decide whether the relevant benchmarks come from the late eighteenth century or from the present day. ${ }^{121}$ This is not to suggest that members of the founding generation expected future interpreters to give the words "cruel" and "unusual" whatever meaning they acquired in later usage. But it is at least possible that the original meaning of the "cruel and unusual" formula, like the original meaning of the "necessary and proper" formula, incorporated some aspects of present-day circumstances as relevant variables.

As Professor Ronald Dworkin has observed, it is also possible that some provisions of the Constitution incorporated principles that

ments "would have been too vague to have been of any consequence, since [these words] admit of no clear and precise signification." Marcus IV (Iredell), Norfolk and Portsmouth J (Mar 12, 1788), reprinted in Kaminski and Saladino, eds, 16 Documentary History of the Ratification 379, 381 (cited in note 40). Members of the First Congress voiced the same complaint when discussing which amendments to propose to the states. See The Congressional Register (Aug 17, 1789), reprinted in Bickford, Bowling, and Veit, eds, 11 Documentary History of the First Congress 1285, 1290 (cited in note 24) (reporting that Rep William Smith "objected to the words 'nor cruel and unusual punishments,' the import of them being too indefinite"); id (adding Rep Samuel Livermore's more general observation that the proposed amendment "seems to have no meaning in it").

Assuming that the phrase "cruel and unusual" was not a term of art referring to a known set of barbaric punishments, it surely implicated questions of degree on which opinions could differ. What level of pain or humiliation makes a punishment "cruel," and how extraordinary must a punishment be to qualify as "unusual"? Reasonable speakers of English might also have disagreed about whether the "cruel and unusual" formula takes account of the nature of the underlying offense or only the nature of the punishment. Does the Eighth Amendment incorporate a principle of proportionality, or does it simply ban the rack and other barbaric mechanisms of punishment for all offenses? See Harmelin v Michigan, 501 US 957, 975-85 (1991) (Scalia joined by Rehnquist) (asserting that "all available evidence of contemporary understanding" supports the latter interpretation); Anthony F. Granucci, "Nor Cruel and Unusual Punishments Inflicted:" The Original Meaning, 57 Cal L Rev 839 (1969) (arguing that the denunciation of "cruel and unusual punishments" in England's 1689 Bill of Rights incorporated the idea that the punishment should fit the crime, but presenting evidence that Americans of the founding generation understood the phrase differently).

120 This question assumes that the phrase "cruel and unusual punishments" was not a term of art and that it can usefully be broken down into its individual components.

121 Contrast Antonin Scalia, Originalism: The Lesser Evil, 57 U Cin L Rev 849, 861-62 (1989) (flagging this potential ambiguity, but expressing a preference for the view that the Eighth Amendment refers to the punishment norms of 1791), with Lawrence Lessig, Fidelity in Translation, 71 Tex L Rev 1165, 1187-88 \& n 82 (1993) (suggesting, in essence, that the original meaning of "cruel" incorporated a benchmark whose content can vary over time). 
do not themselves vary in any way, but whose proper application members of the founding generation did not fully understand. To the extent that the provisions were understood to codify the abstract principles rather than the founding generation's specific views about how those principles applied, the concept of a fixed "meaning" does not prevent subsequent interpreters from applying the provisions differently than members of the founding generation would have.

For an uncontroversial example of this sort of provision in a statutory context, consider the portion of the Immigration and $\mathrm{Na}$ tionality Act of 1952 that denies entry to immigrants with "dangerous contagious diseases." ${ }^{122}$ This language presumably refers to diseases that are in fact contagious rather than to diseases that were thought to $b e$ contagious at the time the statute was enacted. Present-day interpreters trying to apply the statute's "original meaning" will therefore use the best scientific information currently available rather than restricting themselves to the information available in 1952.

Much more controversially, Professor Dworkin has suggested that the Eighth Amendment used the word "cruel" in the same way that the Immigration and Nationality Act used the word "contagious." In his view, the Eighth Amendment did not use "cruel" in a relative sense (to refer to punishment norms that can vary over time) but rather in an absolute sense (to refer to an eternal principle of morality). Dworkin speculates, moreover, that members of the founding generation would have understood the Amendment to codify the abstract principle that they had in mind rather than their specific views about how the principle applied. To see why this understanding of the original meaning of "cruel" matters, suppose that a present-day interpreter continues to believe in the existence of the principle that the framers allegedly incorporated by reference, but disagrees with members of the founding generation about how the principle applies to some particular form of punishment; although members of the founding generation believed that the punishment was consistent with the principle codified in the Eighth Amendment, the present-day interpreter concludes that they were mistaken. Dworkin would have the interpreter hold that the punishment is (and has always been) "cruel" within the meaning of the Eighth Amendment. ${ }^{123}$

Even if Professor Dworkin is wrong about the original meaning of the Eighth Amendment itself, ${ }^{124}$ his argument helps illustrate an im-

122 See Immigration and Nationality Act of $1952 \S 212(a), 66$ Stat 163, 182, current version codified at 8 USC $\S 1182(a)(1)(A)(I)(2000)$. See also Whittington, Constitutional Interpretation at 186 (cited in note 11) (discussing a similar but hypothetical example).

123 See Ronald Dworkin, Comment, in Antonin Scalia, A Matter of Interpretation: Federal Courts and the Law 115, 120-22 (Princeton 1997).

124 See Antonin Scalia, Response, in Scalia, A Matter of Interpretation 129, 145-46 (cited in 
portant point. To say that members of the founding generation envisioned a Constitution with a fixed "meaning" is not to say that they expected all future interpreters to apply each provision of the Constitution exactly as members of the founding generation applied it. Some constitutional provisions surely have the same "fluctuating character" as the Necessary and Proper Clause; their "original meaning" incorporates a direction to take account of present-day circumstances. Other provisions might have the character that Professor Dworkin attributes to the Eighth Amendment. The evidence adduced above, indicating that there is some sense in which members of the founding generation expected the Constitution's meaning to be invariant over time, is in no way inconsistent with either of these possibilities:

Still, this evidence does tend to refute Professor Chemerinsky's claim that originalism "self-destructs." ${ }^{125}$ Even if present-day originalists are bound by the "interpretive intentions" of the founding generation, members of the founding generation do not seem to have anticipated constant reinterpretation of the Constitution. To the extent that the Constitution was determinate, they expected the document itself to "fix" the rules and principles that it articulated. Even to the extent that the Constitution was indeterminate, they expected subsequent practice to liquidate the indeterminacy and to produce a fixed meaning for the future. In short, continuing recourse to the Constitution's "original and authentic meaning"126 does not contradict the founding generation's own interpretive intentions.

\section{The Relevance of the Founders' "Interpretive Intentions"}

Many originalists have offered a more basic response to the claim that founding-era "interpretive intentions" contradict originalism. In their view, the founders' expectations about the interpretive approaches of future generations are simply irrelevant, even for originalists.

This claim grows out of the normative arguments for originalism. Even if the founders' "interpretive intentions" matched the tenets of present-day originalism in every respect, originalists would still need normative arguments for their approach; it would obviously be circular to argue that present-day interpreters must give effect to the original understanding of the Constitution simply because it was the origi-

note 123) (arguing that the Eighth Amendment uses the word "cruel" to refer to "the [ratifying] society's assessment of what is cruel," and that the references to capital punishment elsewhere in the Bill of Rights therefore provide "conclusive evidence that the death penalty is not ... cruel" within the meaning of the Eighth Amendment).

125 See notes 9 and 19-21 and accompanying text.

126 See text accompanying note 74 . 
nal understanding that interpreters would do so. ${ }^{127}$ Sophisticated originalists have therefore developed a variety of external justifications for originalism. ${ }^{128}$ Some originalists have gone on to argue that these normative justifications should persuade present-day interpreters to be originalists even if the founders did not expect future generations to use that approach. In Keith Whittington's words, "[o]riginalism neither depends on the interpretive intent of the founders nor employs that intent." ${ }^{, 29}$

Professor Whittington concedes that if the framers had explicitly codified nonoriginalist instructions in the Constitution itself, then the internal logic of originalism would tell future interpreters to honor those instructions. ${ }^{130}$ But "no such clause exists in the Constitution"; at least on its face, the Constitution gives interpreters only a few scattered instructions, none of which includes "a general directive as to interpretive methodology." ${ }^{, 131}$ Whittington concludes that however members of the founding generation expected future interpreters to proceed, those expectations "did not 'make it' into the Constitution as drafted and ratified." For Whittington, it follows that "an appropriately conceived originalist theory" can survive even if the founders themselves did not share that theory. On this view, the internal logic of originalism does not require consistency with the founders' "interpretive intentions." ${ }^{132}$

Unfortunately, matters are not quite so simple. No originalist believes that the Constitution should be interpreted only according to the rules that it itself sets forth. Instead, the point of originalism is simply that the Constitution should be given its original "meaning" (as that concept is understood by originalists). Different kinds of originalists have somewhat different concepts of "meaning," driven by the different normative justifications that they claim for their particular versions of originalism. But nearly all would agree on the following proposition: In one way or another, the meaning that they are committed to enforcing emerges from the application to the Constitution's words of various legal and linguistic principles that reasonable mem-

127 See Ronald Dworkin, A Matter of Principle 54 (Harvard 1985); Whittington, Constitutional Interpretation at 15 (cited in note 11).

128 The leading treatment is Whittington, Constitutional Interpretation (cited in note 11).

129 Id at 181.

130 See id. Suppose, for instance, that Article VIII had called for "dynamic" interpretation of the rest of the Constitution, effectively delegating power to future interpreters to depart from the initial understanding of the Constitution's text when necessary (in their judgment) to keep constitutional law adequately in tune with current needs and values. Assuming that we could work out the proper understanding of Article VIII itself, originalists would have no warrant to ignore it; the interpretive stance that it identified would presumably control how they approached the rest of the Constitution.

131 Id at $181 \&$ n 59.

132 Id at 181. 
bers of the founding generation would have used to understand those words. ${ }^{133}$ Thus, originalists seeking to identify the Constitution's meaning freely consult (and indeed consider themselves bound to use) founding-era rules of grammar, founding-era conventions about the usages of individual words, founding-era understandings of specialized legal constructions or terms of art, and various other kinds of founding-era conventions and practices. These founding-era conventions all bear on the Constitution's "meaning" (as that concept is understood by originalists) even though the Constitution does not itself codify them.

When originalists think systematically about the linguistic and legal principles that formed the background for the Constitution, they must therefore confront an important question of categorization: Exactly which aspects of the founding generation's ideas about interpretation retain their importance for present-day interpreters of the Constitution? If some founding-era conventions matter and others do not, how should originalists decide which are which? ${ }^{134}$

These are not questions that all versions of originalism will answer in exactly the same way. To be sure, there is a central core of founding-era conventions that bear on what all originalists think of as the Constitution's "meaning" (and that therefore retain their importance for all present-day originalists even if the Constitution does not itself codify them). But different versions of originalism are likely to reach somewhat different conclusions about interpretive practices that fall outside of that core.

Consider, for example, founding-era ideas about the role of subsequent interpretations in "liquidating" and "fixing" the meaning of indeterminate constitutional provisions. Some versions of originalism, which emphasize the desirability of adhering to the system that members of the founding generation thought they were establishing and

133 For purposes of this discussion, I am eliding the differences between theories of original "meaning" and theories of original "intent." By speaking in terms of "meaning," I am using the label that most originalists now prefer. See note 146 and accompanying text. But the point that I am about to make could readily be recast in terms of "intent." As discussed in Part II.A, the distinction between theories of original "intent" and theories of original "meaning" is less significant than some modern commentators suggest.

134 Even though Professor Whittington asserts categorically that originalists need not follow the founders' "interpretive intentions," I do not think that he would disagree with the argument in the text. In his lexicon, the phrase "interpretive intention" refers to "the founders' ideas on theories of interpretation as opposed to substantive constitutional meaning." Whittington, Constitutional Interpretation at 49 (cited in note 11) (emphasis added). If one accepts this definition, then the statement that originalists need not follow the founders" "interpretive intentions" is simply tautological; by definition, something that is an "interpretive intention" does not bear on the "meaning" that originalists are committed to enforcing. But if one uses this terminology, then many founding-era expectations about interpretation are not among the "interpretive intentions" that originalists may disregard. Thus, originalists who use Professor Whittington's terminology still must wrestle with the issue highlighted in the text. 
which take a broad view of that system, may well encourage presentday interpreters to follow settled liquidations simply because members of the founding generation expected the Constitution's indeterminacies to be resolved in this way (and may have designed other features of the constitutional system with that expectation in mind). ${ }^{135}$ But this is not a position that all versions of originalism must take in order to be true to their own normative justifications. In developing a theory of "original meaning," one can coherently distinguish between (1) the conventions that members of the founding generation used to determine a provision's range of permissible interpretations and (2) the practices that members of the founding generation expected future interpreters to follow once a series of interpretations had selected a point within that range. ${ }^{136}$

135 This argument assumes that members of the founding generation not only embraced the liquidation process but also expected all of their successors to do so. If they thought that the liquidation process might be abandoned over time, then the fact that they anticipated its use in the Constitution's early years need not have any bearing on whether the process should continue to be used today, even for those originalists who want to perpetuate the system (broadly conceived) that members of the founding generation thought they were establishing.

136 Even originalists who draw this distinction, of course, will not necessarily reject the concept of "liquidation." While they may not feel compelled to follow the founding generation's expectations on this point, some originalists might conclude that the liquidation process is desirable on its own merits. After all, continuing to adhere to settled liquidations may help to promote the same sort of stability that attracts some people to originalism in the first place. Compare Frank H. Easterbrook, Textualism and the Dead Hand, 66 Geo Wash L Rev 1119, 1121-22 (1998) (defending "[a]n inflexible system of interpretation" on the ground that "[s]tability in a political system is exceptionally valuable"). But other people are drawn to originalism for additional reasons. See, for example, Whittington, Constitutional Interpretation at 111 (cited in note 11) (emphasizing that originalism best preserves the potential for future expressions of popular sovereignty). Depending on how one weighs the various normative arguments for originalism, one might reject the concept of "liquidation" in favor of some alternative approach to indeterminacies in the Constitution's original meaning.

Professor Whittington's position is a good example. In keeping with the idea of "liquidation," Whittington distinguishes between what he calls constitutional "interpretation" (which "represents a search for meaning already in the text") and what he calls constitutional "construction" (which applies when the text's meaning is not fully determinate, and which specifies "a single governing meaning" from the possibilities that interpretation has identified). Id at 6-7. Compare id at 8-9 (extending the concept of constitutional "construction" to apply not only when people resolve textual indeterminancies, but also when they debate how principles reflected in the Constitution should inform policy decisions that the document does not directly control). In a fascinating and important book, he has offered myriad historical illustrations of the process by which political actors and commentators "construct[] constitutional meaning from an indeterminate text." Keith E. Whittington, Constitutional Construction: Divided Powers and Constitutional Meaning 7-8 (Harvard 1999). He argues, however, that these "constructions" of the Constitution's meaning "never leave the realm of politics"; in his view, even settled constructions should never become judicially enforceable. Id at 15 . See also Whittington, Constitutional Interpretation at 11 (cited in note 11) ("The judiciary should seek to enforce the correct interpretation of the Constitution, but it should also avoid enforcing even venerable constructions."). For members of the founding generation, by contrast, settled "liquidations" of the Constitution's meaning operated in a more legally binding sense; they helped to define the law that courts and other actors were obliged to follow. 
Once originalists have decided which founding-era conventions matter, a further wrinkle is theoretically possible: The conventions that we use to determine the Constitution's "meaning" may conceivably tell us that the Constitution itself mandates some additional rules of construction. It is not enough to say, as Professor Whittington does, that the Constitution contains few express instructions about interpretive methodology. Drawing upon whatever founding-era conventions we have identified as relevant, we must also ask whether any other instructions are implicit in the Constitution. Suppose, for instance, that members of the founding generation generally accepted and acted upon the following principle: "Every legal document (or at least every legal document like the Constitution) should be understood to instruct future interpreters to use Approach $X$ unless it explicitly opts out of that approach." On any plausible version of originalism, the meaning of a Constitution adopted against the background of this convention would be identical to the meaning of a Constitution that explicitly mandated the use of Approach $X$.

Again, we can use founding-era expectations about liquidation to illustrate the relevant analysis. Suppose we have determined that those expectations, unless codified somewhere in the Constitution, are not among the interpretive conventions that the internal logic of our particular version of originalism compels us to respect. We still must consider the question of codification: When read in light of the conventions that $d o$ define its "original meaning," does the Constitution instruct future interpreters to honor settled liquidations of its indeterminacies? Here, we may face a conundrum, for it is possible that the answer to this question is itself indeterminate.

On the one hand, reasonable members of the founding generation-applying interpretive conventions of the sort that present-day originalists feel bound to follow-might conceivably have read each indeterminate provision in the Constitution not only to define a range of permissible interpretations, but also to delegate power to the provision's initial interpreters to make an authoritative selection within that range. If this implicit delegation of interpretive authority was part of the provision's "meaning" (as originalists understand that concept), then the internal logic of originalism would require present-day originalists to continue to respect it. ${ }^{137}$

137 The canon of statutory construction reflected in Chevron USA Inc $v$ Natural Resources Defense Council, Inc, 467 US 837 (1984), illustrates how legal texts that do not explicitly delegate interpretive authority to anyone might nonetheless be understood to include an implicit delegation as part of what originalists would consider their "meaning." Chevron holds that when a federal statute puts an administrative agency in charge of administering its provisions, the agency ordinarily enjoys interpretive as well as administrative authority; to the extent that the statutory provisions it administers are ambiguous, the agency gets to choose from among the permissible 
On the other hand, members of the founding generation could have expected future interpreters to use the liquidation process even if no relevant interpretive conventions told them to read this instruction into the Constitution itself. The founders may simply have associated the liquidation process with the so-called "general" law; that is, they may have thought that custom and reason gave interpreters an obligation to follow settled understandings of indeterminate provisions in written laws. ${ }^{138}$ By hypothesis, we are assuming that presentday originalists need not share this view; this feature of the general law is not among the interpretive conventions that all originalists must continue to follow. Accordingly, if an instruction to follow settled liquidations is not itself part of the Constitution's "meaning," then

interpretations, and courts must respect the agency's choice. See id at $842-43$. The Supreme Court understands the statute itself to imply this arrangement. In the Court's words, Chevron deference "is premised on the theory that a statute's ambiguity constitutes an implicit delegation from Congress to the agency to fill in the statutory gaps." FDA v Brown \& Williamson Tobacco Corp, 529 US 120, 159 (2000). See also Chevron, 467 US at 843-44 (speaking in the same terms); Antonin Scalia, Judicial Deference to Administrative Interpretations of Law, 1989 Duke L J 511, 515-16 (noting that if Congress wants to turn off this interpretive presumption, it can opt out of Chevron deference by including a provision to that effect in the statute).

Even if one questions this rationale for Chevron deference as applied in Chevron itself, it may well make sense to read this sort of delegation into the "meaning" of some statutes enacted after Chevron. Given the backdrop of modern administrative law, one might conclude that when Congress authorizes an administrative agency to administer a new statute, Congress should be understood as implicitly requiring Chevron deference unless it opts out of this arrangement. If so, then even if the Supreme Court were to overrule Chevron for statutes enacted before 1984, it might continue to understand some post-Chevron statutes to require Chevron deference. Contrast Cannon v University of Chicago, 441 US 677, 698-99 (1979) (endorsing this sort of argument and applying it to a statute that had been enacted when courts were quite willing to infer private causes of action), with Alexander $v$ Sandoval, 532 US 275, 287-88 (2001) (rejecting Cannon's approach).

Of course, by drawing an analogy between Chevron deference and founding-era concepts of "liquidation," I do not mean to suggest that the two are identical. Quite the contrary is true; the terms of the delegation inferred by Chevron give administrative agencies substantially more freedom to depart from settled understandings than the Madisonian concept of "liquidation." The point of my analogy is limited: I am simply trying to make credible the idea that a legal text might be thought to include an implicit delegation of interpretive authority as part of its "meaning."

138 Compare John Harrison, The Power of Congress over the Rules of Precedent, 50 Duke L $\mathrm{J} 503,505,525-30$ (2000) (concluding that most of the norms of precedent currently followed by federal courts are matters of what used to be called "general" law). Professor Harrison's focusthe rules of stare decisis that courts use to determine the force of past judicial decisions - is a subset of what members of the founding generation would have thought of as the liquidation process. See text accompanying notes 31-38.

For the seminal discussion of conceptions of "general law" in the early Republic, see William A. Fletcher, The General Common Law and Section 34 of the Judiciary Act of 1789: The Example of Marine Insurance, 97 Harv L Rev 1513 (1984). Rules of general law were "not attached to any particular sovereign," whether federal or state, but could nonetheless resolve a whole host of legal questions. Id at 1517. See also Swift v Tyson, 41 US (16 Pet) 1, 18-22 (1842) (discussing the general commercial law, which was one set of such rules). 
present-day originalists are free to consider alternative approaches to the Constitution's indeterminacies.

This latter possibility strikes me as more plausible than the notion that members of the founding generation understood the Constitution itself to require adherence to settled liquidations. But this is not the sort of issue that historical research is likely to let us pin down for sure. The distinction between treating the liquidation process as a command of the general law and treating it as a command of the Constitution is not a distinction that members of the founding generation had any immediate reason to think about; in either case, founding-era interpreters would have used the process. Present-day originalists may therefore be unable to determine whether the legal and linguistic principles of the founding era told interpreters to read indeterminate provisions, enacted against the background of widespread belief in the liquidation process, as themselves incorporating the principle of liquidation. As a result, originalists may face indeterminacy about how to handle the Constitution's indeterminacies. They can embrace the concept of "liquidation" if they choose, but they can also reject it without descending into demonstrable self-contradiction.

\section{THE COHERENCE OF ORIGINALISM}

Critics often assert that even if originalism does not "selfdestruct" in the manner claimed by Professor Chemerinsky, it suffers from other internal problems. Thus, when Attorney General Edwin Meese announced the Reagan administration's commitment to "a Jurisprudence of Original Intention,",139 critics were quick to condemn his approach as incoherent (because the various participants in the process of framing and ratifying the Constitution often disagreed with each other about what the Constitution meant) ${ }^{140}$ or unworkable (because we lack reliable records of what many framers and ratifiers thought about many questions of interpretation). ${ }^{141}$ Leonard Levy

139 Edwin Meese III, Speech before the American Bar Association (July 9, 1985), in The Great Debate: Interpreting Our Written Constitution 1, 9-10 (Federalist Society 1986).

140 See, for example, William J. Brennan, Jr., Speech before the Text and Teaching Symposium at Georgetown University (Oct 12,1985), in The Great Debate 11, 14-15 (cited in note 139) (questioning "whether the idea of an original intention is a coherent way of thinking about a jointly drafted document drawing its authority from a general assent of the states," and buttressing this point by observing that frequently "the Framers themselves did not agree about the application or meaning of particular constitutional provisions").

141 See, for example, James H. Hutson, The Creation of the Constitution: The Integrity of the Documentary Record, 65 Tex L Rev 1,1-2 (1986) (warning that surviving records of the framing and ratifying conventions are unreliable and that " $[t]$ o recover original intent from these records may be an impossible hermeneutic assignment"). See also Levy, Original Intent at 285 (cited in note 9) (asserting that a jurisprudence of original intent is "quite impossible" because "[t]he extant records are simply not sufficiently ample"); Richard H. Fallon, Jr., Implementing the Constitution 14 (Harvard 2001) (observing that "the framing and ratifying generations ... had no occa- 
summed up this line of attack when he asserted that a jurisprudence of the sort Meese advocated "is not really possible, however desirable." ${ }^{142}$

Originalists have tended to respond that these criticisms misunderstand the true nature of originalism: The critics assume that originalists care about the "subjective" intentions of individual members of the founding generation, when in fact originalists are seeking to recover the "objective" meaning of the constitutional text. To be sure, some originalists have indeed portrayed originalism as a search for the actual mental states of the people who participated in framing or ratifying the constitutional provisions in question. In his 1977 book Government by Judiciary, for instance, Raoul Berger urged courts to enforce the "original intention," which he defined as "the meaning attached by the framers to the words they employed in the Constitution and its Amendments." ${ }^{143}$ But more recent originalist rhetoric has deemphasized the (potentially conflicting) views of individual participants in the process of framing and ratification. Instead of privileging the participants' views, most originalists now urge interpreters to ask how an objectively reasonable member of the founding generationapplying the grammatical rules and other interpretive conventions of the day-would have understood the Constitution. ${ }^{144}$ For present-day originalists, the views expressed by individual framers or ratifiers may shed light on this question, but those views are not automatically binding, and disagreement among individual framers or ratifiers does not automatically doom the originalist project. As Attorney General Meese's Office of Legal Policy put it in a 1987 report, “[o]ur fundamental law is the text of the Constitution as ratified, not the subjective intent or purpose of any individual or group in adopting the provision at issue." ${ }^{45}$ In keeping with this view, most originalists have accepted

sion to consider-indeed, they could scarcely have imagined-many of the specific issues that confront policy makers and courts today") (emphasis omitted).

142 Levy, Original Intent at 323 (cited in note 9).

143 Raoul Berger, Government by Judiciary: The Transformation of the Fourteenth Amendment 363 (Harvard 1977). See also Raoul Berger, Constitutional Law and the Constitution, 19 Suffolk U L Rev 1,9 (1985) (suggesting that courts cannot second-guess the framers' interpretation of their words, because "[t]he age-old rule is that the intention of the lawmaker overrides the text; it is the intention that is the law"). Compare Kay, $82 \mathrm{Nw} \mathrm{U} \mathrm{L} \mathrm{Rev} \mathrm{at} \mathrm{230,} 247$ (cited in note 22 ) (focusing on "the intentions of the various ratifying bodies who possessed the constituent authority," and suggesting that judges should "apply the rules of the written constitution in the sense in which those rules were understood by the people who enacted them").

144 See, for example, Randy E. Barnett, The Original Meaning of the Commerce Clause, 68 U Chi L Rev 101, 105 (2001) (emphasizing that the search is not for "the subjective intentions of [the Constitution's] framers or ratifiers," but rather for "the meaning a reasonable speaker of English would have attached to the words, phrases, sentences, etc. at the time the particular provision was adopted").

145 Office of Legal Policy, Original Meaning Jurisprudence at 14 (cited in note 3). See also Antonin Scalia, Common-Law Courts in a Civil-Law System: The Role of United States Federal 
Justice Scalia's suggestion "to change the label from the Doctrine of Original Intent to the Doctrine of Original Meaning."

Originalists suggest that this shift blunts attacks on the coherence of their approach. According to the Office of Legal Policy's report, for instance, critics who think that they can defeat originalism by noting the founders' lack of consensus on various issues (or the gaps in our records of what the founders thought) are "confus[ing] subjective intent with original meaning., ${ }^{, 14}$ Randy Barnett speaks for many originalists when he asserts that "the shift from original intention to original meaning" obviates some of "the most telling practical objections to originalism." ${ }^{148}$

As Part II.A explains, however, this response is not entirely satisfactory. In theory, one can imagine differences between "original intention" and what originalists think of as "original meaning." But in practice, the two concepts surely will match up fairly closely. If "original intention" (in the sense of the framers' or ratifiers' subjective understandings of the Constitution) is indeterminate, then the same is likely to be true of "original meaning."

Part II.B argues that at least some of this indeterminacy can be traced back to founding-era interpretive conventions. As we have seen, certain kinds of linguistic and legal conventions unquestionably bear on what all originalists think of as the Constitution's "original meaning." Even within that core, though, members of the founding generation could reasonably disagree about exactly which interpretive conventions the Constitution triggered. At the time of the framing, somewhat different sets of interpretive conventions had developed for different kinds of common legal documents. But the world had never before encountered a written constitution for a federal system based on the American concept of popular sovereignty. Did such a docu-

Courts in Interpreting the Constitution and Laws, in Scalia, A Matter of Interpretation 3, 38 (cited in note 123) ("What $I$ look for in the Constitution is precisely what I look for in a statute: the original meaning of the text, not what the original draftsmen intended.").

146 Antonin Scalia, Speech before the Attorney General's Conference on Economic Liberties (June 14, 1986), in Office of Legal Policy, Original Meaning Jurisprudence 101, 106 (cited in note 3). See also Randy E. Barnett, An Originalism for Nonoriginalists, 45 Loyola L Rev 611, 620-21 (1999) (asserting that "originalism has [ ] changed" from a doctrine that "seek[s] the subjective intentions of the framers" to one that seeks "the objective original meaning that a reasonable listener would place on the words used in the constitutional provision at the time of its enactment"); George H. Taylor, Structural Textualism, 75 BU L Rev 321, 332 (1995) (noting "turns at the end of the 1980 s by the Reagan Administration's Justice Department, and by Judge Robert Bork, ... to redefine their approaches as methods of discerning original meaning, not original intent"). Keith Whittington is a prominent exception to this trend; his sophisticated defense of originalism retains the label "original intent." See Whittington, Constitutional Interpretation at 3 (cited in note 11) ("This exploration of constitutional interpretation is presented as a defense of a jurisprudence of original intent.").

147 Office of Legal Policy, Original Meaning Jurisprudence at 20 (cited in note 3).

148 Barnett, 45 Loyola L Rev at 621 (cited in note 146). 
ment trigger the rules of interpretation applicable to an ordinary statute? To a treaty? To a contract? Might different aspects of the Constitution implicate different sets of preexisting conventions, so that a hybrid approach was appropriate? Could special canons of construction, not applicable to any ordinary legal documents, be derived from the Constitution's unique context and purpose? If so, what were those canons? The answers to these questions were far from clear, and members of the founding generation expressed a variety of different views. Such disagreements complicate the project of originalism: To the extent that members of the founding generation reasonably disagreed about the rules by which the Constitution should be interpreted, the range of indeterminacy in the document's "original meaning" is inevitably broadened.

Still, just as an inquiry into the interpretive practices prevailing at the time of the founding exposes this extra source of indeterminacy, so too it suggests one possible response. In particular, originalists who are troubled by the potential consequences of this extra indeterminacy may wish to embrace some version of the concept of "liquidation"-even if the internal logic of originalism does not compel them to do so, and even if they might not otherwise make this choice. The liquidation process, after all, can be applied to disagreements about interpretive conventions no less than to disagreements about the meaning of individual words. ${ }^{1.9}$ As a simple example, Part II.C discusses how practice under the Constitution-including precedents established by state ratifying conventions - helped resolve early disagreements about whether to interpret Article I's prohibitions on "ex post facto Law[s]" from the perspective of a layman or a lawyer. Part II.D builds on this example to explore the possible relevance of the "original understandings" manifested by the various bodies that ratified the Constitution.

\section{A. The Shift from "Original Intention" to "Original Meaning"}

At least in theory, there is a distinction between "original intention" and "original meaning." Even when individual framers and ratifiers were sharply divided about the Constitution's meaning on some point, it is certainly possible that one side had the better of the argument. It follows that what originalists think of as "original meaning" can be determinate even when the interpretations acted upon by indi-

149 See, for example, Lambert's Lessee v Paine, 7 US (3 Cranch) 97, 137 (1805) (Paterson) (indicating that the basic approach used in interpreting wills was so well settled as "not to be shaken by judicial authority"); Brutus XII at 73 (cited in note 40 ) (observing that "the court must and will assume certain principles, from which they will reason" in interpreting the Constitution, and adding that Congress would follow the same principles "when they become fixed, by a course of decisions"). 
vidual framers or ratifiers were so varied that we cannot identify an aggregate "original intention."

Still, one can fairly question how often such divergences between "original meaning" and "original intention" really occurred. Most of the framers and ratifiers were smart people who were familiar with the art of reading and writing legal documents. If a significant number of them genuinely understood a constitutional provision in a certain way, they probably had some objective basis for their interpretation. When they were sharply divided about the best interpretation of some provision, one might therefore expect to find objectively reasonable arguments on both sides. ${ }^{150}$ Thus, in the very cases where divisions among the framers and ratifiers make the "original intention" indeterminate, the "original meaning" is likely to be similarly indeterminate.

Even when "original meaning" and "original intention" really do diverge, moreover, our current vantage point makes it difficult for us to discern the distinctions. Modern readers do not have a direct pipeline to "original meaning." To the contrary, the ways in which people used language at the time of the framing, and the range of conventions that framing-era interpreters could be expected to apply to legal documents, were surely more familiar to elite members of the founding generation than they are to us. Accordingly, modern originalist scholarship often uses the actual understandings expressed by individual framers or ratifiers as evidence of the "original meaning"- the meaning that an objectively reasonable person, using words in the way that people used them at the time of the framing and applying the appropriate interpretive conventions, would have understood the Constitution to have. This approach is a perfectly sensible response to our relative unfamiliarity with the legal world of the framing. ${ }^{\text {sit }}$ But it sug-

150 At the moment, I am simply stating this conclusion as an intuitively plausible assertion. Part II.B, however, provides some historical reasons to believe that it is true.

151 Critics of originalism sometimes raise historical arguments against this practice. Members of the founding generation, they note, repeatedly indicated that recollections of the framers' secret debates at the Philadelphia Convention should not influence interpreters' conclusions about the Constitution's meaning. See Powell, 98 Harv L Rev at 921 (cited in note 12) (reporting James Madison's professed "surprise" when George Washington invoked the proceedings in Philadelphia "as a clue to the meaning of the Constitution"), quoting 5 Annals of Congress 775 (Gales and Seaton 1796) (remarks of Rep James Madison on Apr 6, 1796). Indeed, early interpreters often discounted even publicly available records of individual speeches given at the ratifying conventions. See The General Advertiser (Feb 15, 1791), reprinted in William Charles diGiacomantonio, et al, eds, 14 Documentary History of the First Federal Congress 412, 414-15 (Johns Hopkins 1995) (remarks of Rep John Laurance on Feb 4,1791) (downplaying reports of individual speeches in favor of "the sense of those conventions which could be collected from their proceedings and the amendments they proposed"); note 269 (citing additional early criticisms of reliance upon the ratification debates). Some critics have flirted with the idea that the internal logic of originalism requires present-day originalists to eschew these records too, and to confine themselves to the same sources that members of the founding generation would have 
gests that our views of "original meaning" and "original intention" will tend to converge in practice even if the two concepts remain distinct in theory. If the "original intention" is indeterminate because participants in the process of framing or ratification were sharply divided about how best to interpret some provision, we will not always be able to identify a unique "original meaning" either. ${ }^{1.52}$

In any event, even if it were possible to draw sharp distinctions between "original intention" and "original meaning," originalists who did so would risk undermining one of the principal normative arguments for their approach. Consider how originalists respond when

used to discern the Constitution's meaning. See, for example, Paul Finkelman, The Constitution and the Intentions of the Framers: The Limits of Historical Analysis, 50 U Pitt L Rev 349, 352-55 (1989) (suggesting this argument, though not necessarily endorsing it).

This argument is unpersuasive. To begin with, some members of the founding generation who scorned reliance on the records of the ratification debates explicitly based their position on the fact that too little time had passed for such records to be useful. These people did not necessarily claim that the records would never be useful, but simply that they shed little light on "a subject of such recent date as [the] Constitution." 5 Annals of Congress at 657 (remarks of Rep Joshua Coit on Mar 22, 1796).

In any event, one of the principal sources that founding-era interpreters used to discern the Constitution's meaning was the interpreters' own knowledge of the vocabulary, issues, and interpretive conventions of the day. Members of the founding generation did not need to consult records of the Philadelphia Convention or the ratification debates to draw on this knowledge; they were already steeped in the legal climate of late-eighteenth-century America. Modern readers, by contrast, need more help to gain access to this storehouse of information that members of the founding generation took for granted. As one obvious way to get that help, it makes sense to consult records of what well-informed members of the founding generation said about the Constitution. To be sure, those records are spotty and not entirely reliable, and even the statements that they summarize accurately may have been ill informed or otherwise idiosyncratic. But it is still plausible that taking account of these records will, on balance, help present-day originalists reach more accurate decisions about what they think of as the Constitution's "original meaning." See generally Vasan Kesavan and Michael Stokes Paulsen, The Interpretive Force of the Constitution's Secret Drafting History, 91 Georgetown L J (forthcoming 2003) (making a thorough argument for this position).

Nothing in the logic of originalism, moreover, requires present-day originalists to treat the founding generation's stance toward such records as being part and parcel of the "meaning" that originalists are committed to enforcing. By way of analogy, consider how our judicial system handles questions about the content of foreign law. Historically, American courts treated such questions as being questions of fact, susceptible to proof by testimony from witnesses versed in the relevant country's legal system. See Charles Alan Wright and Arthur R. Miller, 9 Federal Practice and Procedure $\$ \S 2441,2444$ at 634, 643 (West 1995). The Federal Rules of Civil and Criminal Procedure now formally categorize such questions as questions of law, but expert testimony about the meaning of foreign laws remains admissible and continues to be part of "the basic mode of proving foreign law." Id at 646 . This is true even though such testimony might well be excluded in the courts of the country whose law is at issue. Thus, we have sensibly distinguished between what we think of as the content of the foreign law and this aspect of the foreign country's methods for discovering that content. We have concluded that even if the foreign judges need no instruction in their own legal culture, expert testimony can still help our courts (which do not have the same background) reach accurate decisions about the content of foreign law.

152 See Ernest A. Young, Alden v. Maine and the Jurisprudence of Structure, $41 \mathrm{Wm} \&$ Mary L Rev 1601, 1639 (2000) (noting that "original meaning and intent are frequently hard to separate, especially where the same sorts of evidence would be used to divine both"). 
people advocate adherence to the Constitution's current meaning (that is, the meaning its words would have if enacted today) rather than its original meaning. ${ }^{153}$ As Steven Smith has suggested in the context of statutory interpretation, letting changes in our language affect our understanding of laws adopted before those changes occurred would tend to "sever[] the link between text and mind"; whether a law's meaning changes (and what it changes to) would depend "less ... on conscious human thought expressed through actual decisions" than on the "historical accident" of how our language happens to develop. ${ }^{154}$ When arguing against current-meaning approaches to the Constitution, originalists emphasize this drawback: To the extent that the Constitution uses words or phrases whose meaning in the general language has changed since ratification, and to the extent that presentday interpreters simply plug the new meaning into the Constitution, the resulting legal rules will not reflect actual policy judgments made by an authoritative decisionmaker. ${ }^{155}$ But the bigger the wedge that originalists drive between "original meaning" and "original intention," the more they open their own approach to the same objection. The more the "original meaning" of the Constitution diverges from what the framers thought they were proposing and the ratifiers thought they were approving, the more "accidental" the law will seem.

Even if it were possible to draw a stark contrast between "original meaning" and "original intention," then, originalists could not really afford to do so. Indeed, Justice Scalia himself has acknowledged that there is "not a big difference" between the two concepts. ${ }^{156}$ But the more "original meaning" resembles "original intention," the more the Jurisprudence of Original Meaning seems vulnerable to the same in-

153 See note 73 and accompanying text (discussing Professor Aleinikoff's proposal for "present-minded interpretation" of statutes). Compare Brennan, Speech Before the Text and Teaching Symposium at 17 (cited in note 140) (decrying attempts to give the constitutional text a "static meaning," and arguing that the "ultimate question" in each constitutional case should be "what do the words of the text mean in our time").

154 See Steven D. Smith, Law Without Mind, 88 Mich L Rev 104, 115 (1989).

155 See, for example, Office of Legal Policy, Original Meaning Jurisprudence at 4 (cited in note 3) ("If courts apply an 'evolving' meaning, ... they are no longer interpreting our basic charter as ratified, and no longer carrying out the will of the governed."). See also Michael J. Perry, The Legitimacy of Particular Conceptions of Constitutional Interpretation, 77 Va L. Rev 669, 689-91 (1991) (invoking Professor Smith's essay as an argument against "nonoriginalist textualism," and stressing the idea that the Constitution "is an intentional political act of a certain sort: an act intended to establish not merely particular configurations of words, but particular political-moral principles (policies, states of affairs, etc.), namely, the principles the particular configurations of words were understood to communicate").

156 Nomination of Judge Antonin Scalia, Hearings before the Senate Committee on the Judiciary, 99th Cong, 2d Sess 48 (1986), reprinted in Roy M. Mersky and J. Myron Jacobstein, eds, 13 The Supreme Court of the United States: Hearings and Reports on Successful and Unsuccessful Nominations of Supreme Court Justices by the Senate Judiciary Committee, 1916-1986 89, 142 (William S. Hein 1989) (testimony of Antonin Scalia on Aug 5, 1986). 
ternal critiques that have been launched against the Jurisprudence of Original Intention. In particular, the distinction between "original intention" and "original meaning" is not a fully satisfying response to critics' objections that members of the founding generation themselves disagreed about the Constitution's import.

\section{B. Which Rules of Interpretation Determine the "Original Meaning"?}

At the outset of Part II.A, I made the following assumption: Sharp divisions in what originalists think of as "original intentions" (that is, in the constitutional interpretations acted upon by individual framers and ratifiers) are likely to reflect indeterminacies in what originalists think of as "original meaning.",57 This Part supports that assumption with historical evidence shedding light on one of the sources of such indeterminacies.

For originalists to deny that indeterminacy in "original intentions" reflects indeterminacy in "original meaning," they must assume the existence of a set of interpretive rules that objectively reasonable members of the founding generation would have used to discern the Constitution's meaning. With those rules in place, originalists can cope with disparities in the "original intentions" by arguing that some participants in the process of adopting the Constitution were simply wrong about the Constitution's (determinate) "meaning": Even though they understood a particular provision in one way, the correct application of the governing interpretive rules really supported a different view.

In the abstract, this emphasis on "meaning" over "intentions" seems quite powerful. It is consistent with how we normally think about law, ${ }^{158}$ and it is also consistent with how members of the found-

157 See text accompanying note 150 .

158 Judge Bork offers the following example: "If Congress enacted a statute outlawing the sale of automatic rifles and did so in the Senate by a vote of 51 to 49 , no court would overturn a conviction because two senators in the majority testified that they really had intended only to prohibit the use of such rifles." Even if these two oddball senators had an idiosyncratic understanding of the word "sale," we expect our courts to give effect to the common usage of that term. See Robert H. Bork, The Tempting of America: The Political Seduction of the Law 144 (Free Press 1990).

In Bork's example, it plainly would make no sense to read "sale" as meaning "use." Aside from any issues of notice to the citizenry, the 49 other senators who supported the measure presumably intended the word to have its ordinary meaning; if a court were tempted to give effect to what the two oddballs thought, some other senators could testify that they had understood the word "sale" to mean "sale," and we would be back where we started. The only plausible alternative to giving the word its ordinary meaning, then, is to treat the statute as having no legal effect at all. Richard Kay seems to flirt with this alternative; he suggests that unless one can "accumulate enough identical intentions to arrive at one authoritative lawmaking intention," a provision has "no ... claim to our allegiance" and "could not make law." See Kay, 82 Nw U L Rev at 249 
ing generation apparently thought about law. ${ }^{159}$ But a less abstract effort to discern the interpretive conventions that actually prevailed at the time of the framing reveals some hidden difficulties. Because of its unprecedented nature, the Constitution was adopted against an unusually unsettled interpretive background. As we shall see, reasonable people could disagree about which conventions would govern its interpretation.

1. Similarities and differences in the rules for interpreting different types of legal documents.

At the time of the founding, there was a fairly broad consensus about the general purpose of interpretation. According to John Locke, "[w] hen a man speaks to another, it is [so] that he may be understood; and the end of Speech is, that those Sounds, as Marks, may make known his Ideas to the Hearer." the Ideas he has, and which he would express by them." interpretation is to identify those ideas; in successful communication, listeners understand a speaker's words to refer to the same ideas that the speaker was using them to express.

The rhetoric used by eighteenth-century lawyers on both sides of the Atlantic reflected this basic conception of interpretation. When interpreting wills, courts described their project as a search for "the intention of the testator. ${ }^{, 162}$ When interpreting statutes, courts talked

(cited in note 22). This view, however, leads to enormous difficulties, and the conclusion that it suggests strikes me as jarring: It does not match our intuitions about what courts would do in Bork's example.

To my mind, Joseph Raz's view of the kind of intentions that are necessary for something "to count as a law-making act" is more plausible than Professor Kay's. See Joseph Raz, Intention in Interpretation, in Robert P. George, ed, The Autonomy of Law: Essays on Legal Positivism 249 (Clarendon 1996). Raz concedes the appeal of the idea that "[i]t makes no sense to give any person or body law-making power unless it is assumed that the law they make is the law they intended to make," id at 258, but he argues for a "very minimal" view of the kind of intention that is indispensable. Id at 267. Raz's view ends up "refer[ring] the courts to the conventions of interpretation prevailing at the time of legislation." Id at 271.

159 See Powell, 98 Harv L Rev at 914-24 (cited in note 12) (concluding that in the immediate aftermath of ratification, few people endorsed what Powell calls "intentionalism"). See also, for example, Hamilton, Opinion on the Constitutionality of an Act to Establish a Bank at 111 (cited in note 117) ("[W] hatever may have been the intention of the framers of a constitution, or of a law, that intention is to be sought for in the instrument itself, according to the usual \& established rules of construction. Nothing is more common than for laws to express and effect, more or less than was intended."); Letter from James Madison to Henry St. George Tucker (Dec 23, 1817), in 3 Letters of Madison 53, 54 (cited in note 27) (calling Madison's knowledge of the views of members of the Philadelphia Convention a possible source of "bias" in his interpretation of the Constitution).

160 John Locke, An Essay Concerning Human Understanding 405 (Clarendon 1975) (Peter H. Nidditch, ed) (originally published 1689).

161 Id at 406 (emphasis omitted).

162 For example, Williams v Dickerson, 2 Root 191, 194 (Conn Super Ct 1795); Kennon v 
about "the intention of the Legislature." ${ }^{, 163}$ For treaties, too, Vattel declared that "the sole object of a lawful interpretation is to discover the intention of the maker or makers of the treaty."164

Despite the widespread use of this rhetoric, though, the interpretation of legal documents raised complications not present in Locke's simple model of communication. To begin with, legal documents often spoke for more than one person, and it was possible that the relevant "speakers" had not all intended their words to express exactly the same ideas. The great French commentator Jean Domat, whose treatise on the civil law was known to and admired by many leading members of the founding generation, ${ }^{165}$ had made precisely this point in discussing differences between the interpretation of wills and the interpretation of contracts. "[I]n testaments," Domat observed, "it is only one Person alone who speaks, and his Will ought to serve as a Law." But a contract spoke for more than one party, and it would not always make sense to resolve the document's ambiguities solely by reference to the intention of the drafter (at least when the other party had not been aware of that intention). ${ }^{160}$

Because of the consequences attached to legal documents, determining the relevant "intention" also presented some special problems of proof. By the time it became necessary to interpret a contract, for instance, one could no longer simply ask the parties to say what they had meant; their interests were likely to have changed since the contract was made, and their answers might therefore be unreliable. ${ }^{167}$

M'Roberts, 1 Va (1 Wash) 96, 102 (1792); Englefried $v$ Woelpart, 1 Yeates 41, 45 (Pa 1791).
163 For example, Brown v Barry, 3 US (3 Dall) 364, 367 (1797).
164 Vattel, Law of Nations at 201 (cited in note 78).
165 See Daniel R. Coquillette, Ideology and Incorporation III: Reason Regulated-The PostRestoration English Civilians, 1653-1735, 67 BU L Rev 289, 349 n 244 (1987) (observing that William Strahan's translation of Domat's treatise "was a favorite of the most important American revolutionaries and early American jurists"). See generally R.H. Helmholz, Use of the Civil Law in Post-Revolutionary American Jurisprudence, 66 Tulane L Rev 1649 (1992) (tracing citations to Domat and other civilians in reports of cases from the early American Republic).

166 See Jean Domat, 1 The Civil Law in Its Natural Order lxxviii (Midwinter, et al, 2d ed 1737) (William Strahan, trans). See also, for example, Executors of Rippon $v$ Executors of Townsend, 1 SCL (1 Bay) 445, 449 (1795) (noting that individual members of the state legislature might not all have had the same intentions about the meaning of a statute).

167 See, for example, Hugo Grotius, The Rights of War and Peace 352 (Innys, et al, 1738) (Jean Barbeyrac, ed) (originally published 1625) ("[B]ecause the inward Acts and Motions of the Mind are not in themselves discernible, and there would be no Obligation at all by Promises, if every Man were left to his Liberty, to put what Construction he pleased upon them, therefore some certain Rule must be agreed on, whereby we may know, what our Promises oblige us to ...."); Samuel Pufendorf, The Law of Nature and Nations 534 (Bonwicke, et al, 5th ed 1749) (Basil Kennet, trans) ("[T]here would be no such Thing as Obligation, if any one might free himself, by affixing what Sense he pleased to his Signs, and by pretending that he meant different from their true Signification."); Vattel, Law of Nations at 200 (cited in note 78) ("[I]f I am to be allowed to explain my promises after my own pleasure $I$ shall have it in my power to render them meaningless and of no effect by giving them a meaning quite different from that they had 
Similarly, the meaning of a statute could not reliably be determined by asking individual legislators to testify after the fact about what they had intended; this procedure would "afford[] great room for partiality and oppression," because legislators might shape their testimony according to the identity of the interested parties. ${ }^{1.8}$ Even apart from considerations of reliability, there were other grounds for opposing this method of determining the relevant "intention." Statutes imposed obligations on people who had not had a hand in making them, and it seemed wrong to bind these people to intentions about which they could not have known at the time they acted.'

For all these reasons, courts and commentators alike agreed upon the need for some definite "rules for determining the meaning to be given to the language used." ${ }^{, 170}$ Locke's understanding of interpretation provided the guiding principle for these rules: Within the constraints of the rule-based approach, the rules should be designed to capture the likely intent of the people for whom a document spoke. ${ }^{171}$ Still, an interpretation could be correct even if one or more of the document's makers had actually meant to express something else. ${ }^{172}$

for you when you accepted them.").

168 Blackstone, 1 Commentaries at 58 (cited in note 79).

169 Compare Rutherforth, 2 Institutes at 301 (cited in note 79) ("We cannot ... be obliged to comply with [the legislator's] will; where we do not know what his will is. And we can no otherwise know what his will is, than by means of some outward sign or mark, by which this will is expressed or declared.").

170 Vattel, Law of Nations at 201 (cited in note 78).

171 See, for example, Blackstone, 1 Commentaries at 59-61 (cited in note 79) (listing some rules for interpreting statutes, and describing these rules as ways to "explor[e] [the legislator's] intentions at the time when the law was made, by signs the most natural and probable"); Vattel, Law of Nations at 201 (cited in note 78) (asserting that the rules for interpreting treaties and contracts should be "adapted to determining the meaning of the contract as it was naturally understood by the parties when drawn up and accepted") (emphasis omitted); Pufendorf, Law of Nature and Nations at 535 (cited in note 167) ("The true End and Design of Interpretation is, to gather the Intent of the Man from most probable Signs."); Grotius, Rights of War and Peace at 353 (cited in note 167) ("The best Rule of Interpretation is to guess at the Will by the most probable Signs ....").

172 See, for example, Executors of Rippon, 1 SCL (1 Bay) at 449 (observing, in interpreting a statute, that "it would be wrong for us to give [a] different meaning than the law affixes to a legal technical term ... merely from an idea that the legislature meant to do so, which perhaps they did not, though some particular member might have had such an intention"); John Joseph Powell, 1 Essay upon the Law of Contracts and Agreements 372-73 (Garland 1978) (originally published 1790):

[W] hatever difference there may be between a man's internal sentiments and external expression, he must, in his ordinary transactions with mankind, be concluded to use signs according to their common acceptation .... Therefore he, in whose favour an obligation is incurred, has a right to compel him, from whom it is due, to perform it in that sense, which the ordinary interpretation of the signs made use of import.

See also Grotius, Rights of War and Peace at 352 (cited in note 167) (agreeing that "natural Reason will tell us, that the Person to whom the Promise is given, has a Power to force him who gave it, to do what the right Interpretation of the Words of his Promise does require"). 
Some of the rules of interpretation applied to all different sorts of legal documents, and indeed to communication in the English language more generally. Unless the context indicated otherwise, for instance, interpreters were to presume that the makers of a legal document had been using words and grammatical constructions in a manner "agreeable to common usage" rather than in some idiosyncratic way. ${ }^{173}$ The presumption against surplusage also applied broadly; other things being equal, interpretations that recognized a role for all of the document's words were deemed more likely to reflect the intended meaning than interpretations that made some of those words superfluous. ${ }^{1 / 4}$ When interpreters could determine "the purpose which has led the speaker to act," it too could shed light on the sense in which the speaker had been using ambiguous phrases. ${ }^{175}$ By the same token, interpreters hesitated to read documents to establish bizarre rules; ambiguities tended to be resolved in light of customary outcomes, so that it required a clearer statement to accomplish something surprising and unusual than something routine ${ }^{176}$ All these commonsensical principles applied across the spectrum of legal documents.

Still, there were many rules of interpretation that applied only in certain contexts or only to certain types of legal documents. ${ }^{177}$ As Do-

173 Rutherforth, 2 Institutes at 319 (cited in note 79) (discussing contracts, wills, and statutes). See also, for example, Blackstone, 1 Commentaries at 59 (cited in note 79) (discussing statutes); Vattel, Law of Nations at 202 (cited in note 78) (discussing treaties, contracts, and promises); Grotius, Rights of War and Peace at 353 (cited in note 167) (discussing treaties).

174 See Rutherforth, 2 Institutes at 325-26 (cited in note 79). See also, for example, Chapman's Administratrix v Turner, 5 Va (1 Call) *280, *287 (1798) (Roane) (calling this principle "an universal rule of interpretation" and applying it to a written agreement); Ware v Hylton, 3 US (3 Dall) 199, 209 (1796) (argument of counsel) (applying this principle in the interpretation of a treaty); Sealy v Laurens, 1 SC Eq (1 Des) 137,140 (Ct Ch 1787) (Hutson) (applying this principle in the interpretation of a will); Toogood $v$ Scott, $2 \mathrm{H} \& \mathrm{McH} 26,32-33$ (Md 1783) (argument of counsel) (applying this principle in the interpretation of a statute).

175 Vattel, Law of Nations at 207 (cited in note 78) (discussing interpretation of laws, promises, and treaties). See also Rutherforth, 2 Institutes at 328-29 (cited in note 79) (noting that "[t]he reason or final cause of a law" can help resolve doubts about the intended meaning of the law's words).

176 See, for example, Belt's Lessee v Belt, 4 H \& McH 80, 84 (Md 1799) (argument of counsel) (invoking the "established rule" that a will would not be read to disinherit an heir at law unless the testator's intention to do so was "plain"); Vattel, Law of Nations at 214 (cited in note 78) (indicating that "in doubtful cases" treaties should not be read "to change the present state of things"). Compare Lawrence v Dorsey, $4 \mathrm{H} \& \mathrm{McH} 205,208$ (Md Ch 1798) (arguing that the absurdity of the consequences produced by one construction of a statute was a strong reason to believe "that such a construction of the law was not intended by its framers," and adding that "had they indeed intended to give the law an operation, against which the sense of mankind, and the principles of this Court would revolt, is it not reasonable to suppose they would have taken care to bind the court by such explicit terms as would plainly shew their meaning, and such as the court could not evade?"); Auditor of Public Accounts v Graham, 5 Va (1 Call) *475, *476 (1798) (Roane) (invoking the general rule that in the absence of "express legislative words," statutes would not be read to deprive people of jury trials).

177 See Powell, 98 Harv L Rev at 896 (cited in note 12) (noting that founding-era interpretive techniques "varied according to the type of instrument to be construed"). 
mat cautioned, it was important for students and interpreters alike "to observe, and to distinguish the Rules which are common to all Matters without Distinction[;] those which extend to several Matters, but not unto all[;] and those which are peculiar only to one ....",178

Some of the variation in rules of construction reflected differences in the circumstances under which different sorts of legal documents were commonly made (or under which decision-makers wanted them to be made). When construing deeds, for instance, courts tended to indulge a blanket presumption that the operative language reflected technical advice or knowledge; if a deed failed to use the terms of art that the law associated with certain sorts of conveyances, courts concluded that the deed had not been intended to make those conveyances. $^{179}$ Lawyers justified this presumption by observing that "a Man may have Advice \& Assistance in drawing of Deeds [a]nd it is his own Folly if he has not." ${ }^{180}$ When interpreting wills, by contrast, courts took a much more forgiving approach, in recognition of "the extremity in which [wills] are often made, not admitting of counsel being called in." Thus, while interpreters of both wills and deeds were said

178 Domat, 1 Civil Law in Its Natural Order at lxxviii (cited in note 166).

179 See Matthew Bacon, 5 A New Abridgment of the Law 522 (W. Strahan 4th ed 1778) ("In Deeds the Rule of Construction is, That the Intention must be directed by the Words ...."). Compare Bradley v Mosby, 7 Va (3 Call) *50, *60 (1801) (Lyons):

Although it be a rule that in the construction of writings the intention of the parties ought to prevail, yet that rule does not extend so far as to overturn the established interpretation which has, for ages, been put upon certain expressions; the legal effect of which, in particular instruments, has been constantly held to convey the absolute property.

See also Hawkins v Thornton, 2 Va Colonial Dec B243, B244 (Gen Ct 1737) (argument of counsel) ("In Deeds the Wisdom of the Law has appropriated certain peculiar Words as Terms of Art not to be supplied by any other \& without which an Estate [in fee simple or fee tail] ... cannot pass or be created ....").

180 Hawkins, 2 Va Colonial Dec at B244 (argument of counsel).

181 See William Blackstone, 2 Commentaries on the Laws of England 381 (Chicago 1979) (originally published 1766) ("[M]any times the law dispenses with the want of words in devises, that are absolutely requisite in all other instruments."). See also Bryan $v$ Bradford, $1 \mathrm{Ky}$ (Hughes) 108, 116 (1795) (argument of counsel) (quoting Blackstone); Hawkins, 2 Va Colonial Dec at B244 (argument of counsel) (noting that because of the contrasting approaches to terms of art, "[t]he same Words will not have the like Operation or Effect in [a deed] as in [a will]").

182 Kennon, $1 \mathrm{Va}$ at 102 . See also, for example, Bryan, $1 \mathrm{Ky}$ at 116 (argument of counsel) (attributing the benign interpretation of wills to the fact that dying men tended to be "inops consilii," or without the assistance of counsel); Smither $v$ Smithers, 2 Va Colonial Dec B130, B135 (Gen Ct 1741) (argument of counsel) (acknowledging that "[ $t$ ] he Law gives a favourable interpretation to Wills upon a supposition that they are made in a Mans last moments when he has not opportunity for good advice"); Blackstone, 2 Commentaries at 381 (cited in note 181) (explaining the "favourabl[e]" interpretation of wills on the ground that the testator may have lacked legal "advice or learning"). The differences between the interpretation of wills and the interpretation of deeds may also have reflected Domat's point that a will spoke for only one person, while deeds often resulted from contractual negotiations. A flexible approach to the text might have been deemed better suited for advancing the intention of a single testator than for aggregating the intentions of multiple people. Compare note 167 and accompanying text. 
to seek "the intention of the makers," "the rules of construction applicable to these two kinds of instruments[] are entirely different and even incompatible."

In the realm of statutory interpretation, the same basic idea was sometimes said to support a distinction between the rules for interpreting statutes adopted by expert legislators and the rules for interpreting statutes enacted by people with less legal training. The rules for interpreting statutes, like the rules for interpreting other legal documents, were supposed to help identify the meaning that the enacting legislature had probably intended to convey. But some of those rules were sufficiently technical that they could reliably reflect the enacting legislature's intention only if the legislators had been aware of them and had kept them in mind during the legislative process. ${ }^{185}$ Founding-era lawyers advocated different rules for statutes enacted by colonial legislatures that were unlikely to have this sort of expert knowledge.

Other variations in the applicable rules of interpretation reflected differences in the degree of care with which the makers of a document were presumed to have chosen their words. Consider, for instance, the approach known as "liberal interpretation" or "equitable construction," under which the known purpose behind a legal document could sometimes justify inferring exceptions to seemingly unqualified text or extending seemingly limited text to cover additional situations. ${ }^{187}$ At

183 For example, Butler v Boarman, $1 \mathrm{H} \& \mathrm{McH} 371,376$ (Md Prov Ct 1770) (argument of counsel).

184 Jacks v Henderson, 1 SC Eq (1 Des) 543, 549 (Ct Ch 1797) (argument of counsel). Accord Lambert's Lessee v Paine, 7 US (3 Cranch) 97, 137 (1805) (Paterson) (indicating that the difference between the interpretation of wills and the interpretation of deeds "is a leading axiom in our system of jurisprudence"); Hawkins, 2 Va Colonial Dec at B244 (argument of counsel) (noting that "there is a great Difference between Deeds \& Wills in the Construction \& Exposition of them").

185 To take just one example, a statute that "repealed" an earlier law was deemed not to affect actions taken while the earlier law had been in force, but a statute that declared the earlier law "null" was understood to wipe the law off the books as if it had never existed. See Matthew Bacon, 4 A New Abridgment of the Law 638 (W. Strahan 4th ed 1778) (Statute (D)13). Compare Story, Law, Legislation, and Codes at 360-63 (cited in note 72) (listing twenty-one fairly general rules of statutory interpretation, but adding that there are also "many other rules, of a more special character," which are "too numerous to be dwelt upon in this place").

186 See Butler, $1 \mathrm{H} \& \mathrm{McH}$ at 379-80 (note appended to case):

[T] he Parliament in England understood the legal import of all the terms commonly used in acts of Parliament, and therefore the legal import of the terms they use must be understood to express their meaning. But it cannot be supposed that a Maryland Assembly in 1681 understood the legal import of all the terms used, and therefore it would be a very unsafe rule to judge in all instances of their intention by the legal import of the terms they used.

187 See Rutherforth, 2 Institutes at 339 (cited in note 79) (explaining that under this approach, which Rutherforth referred to as "liberal" or "rational" interpretation, "sometimes we restrain the meaning of the writer, so as to take in less, and sometimes we extend or enlarge his meaning, so as to take in more, than his words express"). 
least as applied to statutes, this approach certainly had its critics. ${ }^{188}$ But even its supporters agreed that certain kinds of statutes did not trigger it. For instance, so-called "explanatory" statutes-statutes that sought to declare exactly what the legislature understood some preexisting law to mean-were often said to be exempt from equitable construction. ${ }^{189}$ More generally, jurists sometimes suggested that equitable construction was ill suited for all modern statutes, which were drafted more carefully than "ancient Acts of Parliament" and which allegedly should be presumed to include the exceptions and embellishments that the legislature wanted. ${ }^{100}$

Still other differences in the rules for interpreting different sorts of statutes were driven by differences in what was at stake. Statutes defining crimes, for instance, were "always to be construed strictly, for the benefit of the subject." ${ }^{191}$ The same was true of statutes that imposed penalties recoverable through civil process. ${ }^{192}$ If a penal statute's words could reasonably be understood in more than one sense, inter-

188 See, for example, Swift, 1 System of Laws at 49 (cited in note 38):

[T] his mode of construing law, gives too great latitude to judges, and may be improved to oppressive purposes. It destroys that uniformity, certainty and precision, which are the essence of law. It throws the rights of mankind afloat, by placing them upon the arbitrary opinions and capricious whims of judges. The lawyer can never tell, how to advise his client, and the people cannot know the law. This rule therefore should be admitted with great caution, and practised upon with great prudence.

See also James Wilson, Lectures on Law (1790-1792), in James DeWitt Andrews, ed, 2 The Works of James Wilson 123 (Callaghan 1896) (speaking more favorably of recognizing unstated exceptions in "cases ... which the legislator himself, had he foreseen them, would have specified and excepted," but acknowledging that "[s]uch interpretation ... ought to be made with the greatest circumspection" and "is not to be used, unless where the strongest and most convincing reasons appear for using it"). For modern scholarly debate about early American attitudes toward the "equitable construction" of statutes, contrast John F. Manning, Textualism and the Equity of the Statute, 101 Colum L Rev 1, 8-9, 78-102 (2001) (arguing that founding-era Americans were divided about the propriety of this approach, that the approach "never gained a secure foothold in the federal courts," and that during Chief Justice Marshall's tenure a consensus developed against the approach), with William N. Eskridge, Jr., All About Words: Early Understandings of the "Judicial Power" in Statutory Interpretation, 1776-1806, 101 Colum L Rev 990 (2001) (suggesting that while the use of equitable construction to extend statutes was controversial at the time of the founding, the use of the technique to infer exceptions to statutes was widely accepted).

189 See, for example, Rutherforth, 2 Institutes at 365-66 (cited in note 79).

190 Bradley v Clark, 101 Eng Rep 111, 113-14 (KB 1793) (Buller). Accord Bradford $v$ Treasurer of East Tennessee, 7 Tenn (Peck) *425, *436-37 (1824) (Whyte); Browne v Blick, 7 NC (3 Mur) 511, 521-22 (1819) (Taylor); The Schooner Adeline and Cargo, 13 US (9 Cranch) 244, 255 (1815) (argument of counsel).

191 Swift, 1 System of Laws at 50 (cited in note 38). Accord Blackstone, 1 Commentaries at 88 (cited in note 79).

192 See Story, Law, Legislation, and Codes at 362 (cited in note 72) (differentiating between "penal statues" and "statutes for the punishment of crimes," but saying that both "are always construed strictly"). See also, for example, Washburn $v M^{\prime}$ 'Inroy, 7 Johns *134, *136 (NY Sup Ct 1810) (strictly construing a statute creating a penalty, recoverable in an action of debt, for selling liquor without a license). 
preters were to adopt the "most lenient" construction. ${ }^{193}$ Similarly, although equitable construction might perhaps be used to infer exceptions to penal statutes, it would not be used to expand such statutes; even if the legislature's purpose seemed to justify a broader prohibition than set forth in the statutory text, courts agreed that penal statutes should not "be extended beyond the letter.","le

Variations in the rules of construction applicable to different kinds of legal documents also reflected differences in the documents' theoretical underpinnings. For example, the law of nations proceeded upon the premise that each nation - strong or weak, big or small-was by nature equal to all other nations. ${ }^{195}$ This tenet generated a special approach to the interpretation of treaties: Interpreters were to "extend what makes for equality and restrict what destroys it." classified as "favorable" any treaty provision that "makes for the common benefit of the contracting parties and tends to put them on a footing of equality," and he wrote that such provisions "should be given the widest meaning of which they are susceptible according to common use"; conversely, so-called "objectionable" provisions (which "tend[ ] to destroy the equality of a contract," as by "burden[ing] only one of the parties, or one more than the other") should be understood "in their most restricted sense." ${ }^{197}$ On this logic, treaty provisions requiring cessions of sovereignty were sometimes said to call for restrictive construction. ${ }^{199}$

Aside from these general rules about how to approach various kinds of legal documents, courts and commentators had developed many more specialized rules to handle issues that commonly arose in the interpretation of particular sorts of instruments. These rules oper-

193 Story, Law, Legislation, and Codes at 362 (cited in note 72).

194 See, for example, Church $v$ Thomson, 1 Kirby 98, 99 (Conn Super Ct 1786) (expressing this view, albeit over a dissent). Compare Vanhorne's Lessee v Dorrance, 2 US (2 Dall) 304, 316 (CCD Pa 1795) (jury charge of Paterson) ("A statute should never have an equitable construction in order to overthrow or divest an estate.").

195 See, for example, Vattel, Law of Nations at 7 (cited in note 78):

Since men are by nature equal, and their individual rights and obligations the same, as coming equally from nature, Nations, which are composed of men and may be regarded as so many free persons living together in a state of nature, are by nature equal and hold from nature the same obligations and the same rights. Strength or weakness, in this case, counts for nothing. A dwarf is as much a man as a giant is; a small Republic is no less a sovereign State than the most powerful Kingdom.

196 Id at 214.

197 Id at 212-16. Accord Grotius, Rights of War and Peace at 356-57 (cited in note 167) (categorizing promises as "favourable" or "odious" according to whether they "carry in them an Equality, and respect the common Advantage," or "lay the Charge and Burden on one Party only, or on one more than another").

198 See, for example, Glasgow's Lessee v Smith, 1 Tenn (1 Overt) 144, 166 (Super Ct 1805). See also note 188 and accompanying text (citing invocations of this idea by other courts and commentators). 
ated as defaults; in the absence of contrary provisions in the relevant document, they told interpreters what to do with the issues that they addressed, and they thereby provided a background against which the documents could be drafted. Rules of this sort addressed whether peace treaties barred subsequent suits for injuries caused by the war, whether statutes that had been repealed sprang back into force when the acts containing the repeals were themselves repealed, ${ }^{200}$ and a host of other recurring issues. Since different types of legal documents tended to present different sets of issues, it should come as no surprise that the relevant default rules varied accordingly. ${ }^{201}$

2. Debates over the rules of construction applicable to the Constitution.

Because different types of legal documents triggered different rules of construction, early interpreters of the Constitution had to decide which set (or sets) of rules it implicated. This question, however, did not necessarily have a determinate answer. The Constitution was a novel type of legal document; it was not exactly like a statute, or a treaty, or a contract, or indeed anything that lawyers had previously had to interpret. As one South Carolina jurist later summed up the problem, " $[\mathrm{t}]$ he Constitution of the United States ... is so unlike those instruments for which the common law has provided rules of construction, that a Court must always feel itself embarrassed whenever called upon to expound any part in the smallest degree doubtful., ${ }^{202}$

The Constitution's status as "fundamental" law added an additional layer of difficulty, for it arguably triggered an entirely different approach than any of the "ordinary" legal documents that lawyers usually confronted. ${ }^{203}$ To be sure, some of the states had already

199 See Vattel, Law of Nations at 351 (cited in note 78) (indicating that in the absence of contrary provisions, peace treaties were understood to bar claims for injuries caused by the war, but not claims that had existed before the war and had "formed no part of the motives for undertaking the war").

200 See Swift, 1 System of Laws at 50 (cited in note 38) ("If a statute repealing another, be afterwards repealed, the first statute is revived without any express words, by mere implication."); Blackstone, 1 Commentaries at 90 (cited in note 79) (similar). The opposite default rule now seems to prevail, at least for federal statutes. See 1 USC $\$ 108(2000)$ ("Whenever an Act is repealed, which repealed a former Act, such former Act shall not thereby be revived, unless it shall be expressly so provided.").

201 See, for example, Hamilton $v$ Eaton, 11 F Cas 336, 338 (CCD NC 1792) (observing that "such an instrument as the treaty of 1783 [which ended the Revolutionary War] cannot be subject to the ordinary rules of construction which govern the exposition of statutes of a particular state"); Story, Law, Legislation, and Codes at 360 (cited in note 72) (noting that the common law's maxims for interpreting statutes "allow[] some distinction" according to the kind of statute in question).

$202 M^{\prime}$ Clarin v Nesbit, 11 SCL (2 Nott \& McCord) *519, *520 (Ct Const App 1820) (Huger).

203 Sylvia Snowiss and Larry Kramer both have argued that the Constitution was originally understood as "a political instrument different in kind from ordinary law," rather than simply a 
adopted written constitutions based on notions of popular sovereignty. When the federal Constitution took effect, however, its state counterparts were still too young to have generated a canonical set of interpretive rules, and in some respects the federal Constitution was a different creature anyway; having been adopted for a federal system whose separate units at least arguably retained a measure of sovereignty, it raised interpretive questions not presented by any of the existing state constitutions.

Predictably, people who discussed the Constitution's meaning proposed a variety of different interpretive approaches. During the debates over ratification, indeed, Federalists and Anti-Federalists divided over whether one should read the Constitution like a lawyer at all, or instead should understand the document as a layman would. To meet Anti-Federalist objections about particular provisions, Federalists often advanced lawyerly reasons why the provisions were narrower than the Anti-Federalists suggested; the provisions were said to be written against the backdrop of other legal rules that would constrain their effect ${ }^{24}$ or to use special terms of art whose technical meaning was narrower than their ordinary meaning. ${ }^{205}$ Anti-Federalists responded that if the Constitution needed to be read in this technical way, then ratification should be defeated for that reason alone. As Patrick Henry exclaimed, "[a] Constitution [ ] ought to be like a beacon,

super-statute or some other supreme version of ordinary law. Snowiss, Judicial Review and the Law of the Constitution at 1-3 (cited in note 38). See also Kramer, 115 Harv L Rev at 10 (cited in note 38) (agreeing that "[t]he Founding generation" did not see the Constitution as ordinary law but instead as "a special form of popular law, law made by the people to bind their governors, and so subject to rules and considerations that made it qualitatively different from ... statutory or common law"). The distinction identified by Professors Snowiss and Kramer was certainly in the air at the time of the framing. But to the extent that thinking of the Constitution as "popular law" suggested a different interpretive approach than thinking of it as a super-statute, the ideas described by Professors Snowiss and Kramer were not the only things that were in the air; they simply reflected one of the possible ways in which interpreters could approach the Constitution.

204 See, for example, Nelson, 115 Harv L Rev at 1592-94 (cited in note 8) (discussing Federalist responses to the Anti-Federalists' claim that Article III would expose unconsenting states to suit by individuals).

205 See, for example, Debates of the Virginia Convention (June 17, 1788) at 1359-60 (cited in note 112) (remarks of Edmund Randolph) (responding to Anti-Federalist objections about the breadth of the Ex Post Facto Clause by arguing that the key phrase, when "taken technically," related solely to "criminal jurisprudence" and did not forbid other sorts of retrospective laws); Debates of the Virginia Convention (June 14,1788) at 1293-94 (cited in note 107) (remarks of Henry Lee) (responding to Anti-Federalist objections about the second Militia Clause of Article I, $\S 8$, by arguing that the word "organizing" is a technical term of art). See also Brutus XI at 513 (cited in note 24) (observing that "[i]n a number of instances, where objections are made to the powers given to the judicial, [the advocates of the Constitution] give such an explanation to the technical terms as to avoid them"); Debates of the Massachusetts Convention (Jan 30,1788), in Kaminski and Saladino, eds, 6 Documentary History of the Ratification 1366, 1369 (cited in note 24) (remarks of Thomas Dawes, Jr.) (reflecting doubts about whether to give "a popular or technical construction" to terms in Article III). 
held up to the public eye so as to be understood by every man."206 But Anti-Federalists also questioned whether the Constitution's words would indeed be read in their technical sense. To the extent that the Constitution was understood as a document proceeding from the people, technical constructions of the sort favored by lawyers might simply be misplaced. ${ }^{20}$

Even if one got past this point and accepted the applicability of some technical rules of construction, it was far from clear which rules would be applicable. For a glimpse of the founding generation's uncertainty on this score, one need only consider the varying accounts that modern scholars have offered. On the one hand, Professor Powell's seminal article about the founders' interpretive intentions asserts that the Constitution's framers, ratifiers, and first decade of interpreters usually analogized the Constitution to a statute and applied the "thenprevalent methods of statutory construction." ${ }^{208}$ On the other hand, Professor Sylvia Snowiss suggests that "application to the Constitution of the rules for statutory interpretation" was an innovation introduced by Chief Justice Marshall in the 1810s and did not reflect early interpretive practice. ${ }^{209}$ The fact that two scholars can advance evidence for

206 Debates of the Virginia Convention (June 23, 1788), in Kaminski and Saladino, eds, 10 Documentary History of the Ratification 1464, 1466 (cited in note 24). See also Debates of the Virginia Convention (June 20,1788) at 1421 (cited in note 108) (remarks of Patrick Henry) ("Poor people do not understand technical terms - Their rights ought to be secured in language of which they know the meaning. As they do not know the meaning of such terms, they may be injured with impunity."). Compare Powell, 98 Harv L Rev at 889-94, 907-13 (cited in note 12) (linking similar views expressed by the Anti-Federalist Brutus to "the anti-interpretive tradition of Anglo-American Protestantism").

207 See, for example, Debates of the Virginia Convention (June 16, 1788) at 1304 (cited in note 111) (remarks of George Mason) (expressing dissatisfaction with Henry Lee's interpretation of the second Militia Clause, because Mason "thought that they were not confined to the technical explanation"); Debates of the Virginia Convention (June 17, 1788) at 1361 (cited in note 112) (remarks of George Mason) (discussing the Ex Post Facto Clause, and invoking "the common acceptation of the words" rather than "[w]hatever it may be at the bar, or in a professional line"); Debates of the Virginia Convention (June 20,1788) at 1423 (cited in note 108) (remarks of Patrick Henry) (invoking "the usual meaning of the language of the people" in response to the Federalists' lawyerly arguments about why states would remain protected against suits by individuals). See also Clason $v$ Shotwell, 12 Johns *31, *61 (NY 1814) (Sen Sandford):

[The state constitution] is not the act of a bench of judges, or a bar of lawyers. It is the public act of a numerous body, in which the representatives of the people speak in the language of the people, and address themselves to all mankind. Their language should, therefore, be understood according to the ordinary and usual sense of the terms which they employ.

208 See Powell, 98 Harv L Rev at 904 (cited in note 12) (framers); id at 905 (ratifiers); id at 923, 948 (other early interpreters). In a later article, Professor Powell retreats from his suggestion about the first decade of interpreters. See H. Jefferson Powell, The Political Grammar of Early Constitutional Law, 71 NC L Rev 949, 955 (1993) ("The emergence of severe disagreement on the interpretation of the Federal Constitution in the early 1790 s produced extensive debate over the appropriate methods of interpreting the constitutional text.").

209 See Snowiss, Judicial Review and the Law of the Constitution at 3,121-22 (cited in note 38). 
such diametrically opposed claims is a testament to the variety of approaches that early interpreters actually used. As Professor Powell maintains, references to the rules of statutory interpretation were indeed common from the start. ${ }^{210}$ But the analogy between statutory and constitutional interpretation was not as solid as Professor Powell's article suggests; at least with respect to some issues, people debating the Constitution's meaning often suggested competing rules of construction.

Lawyers sometimes maintained, in fact, that because the Constitution was "new and original" and "ha[d] no reference to any former act or instrument," interpreters should not "resort to any other rules of construction than such as are furnished by the constitution itself, or the nature of the subject."211 Early debates about the meaning of the Constitution often featured elaborate arguments about special rules of construction that allegedly flowed from the Constitution's nature and spirit. Even people who did not consider such rules the only permissible tools for construing the Constitution plainly thought that they were among the permissible tools.

Consider, for instance, the First Congress's famous debates in 1789 about the President's authority to remove principal officers in the executive branch. ${ }^{212}$ While many people thought that the Constitution implicitly gave the President some such authority, ${ }^{213}$ they expressed different views - reflecting different rules of constructionabout the precise nature of this authority. Some members of Congress

210 See, for example, Donaldson v Harvey, 3 H \& McH 12, 19 (Md Gen Ct 1790) ("In expounding the Federal Constitution, the same rules will be observed which are attended to in the exposition of a statute.").

211 United States v Burr, 25 F Cas 55, 116 (CCD Va 1807) (argument of counsel):

[A]rtificial rules of construction, drawn from the common law and the usages of courts in construing statutes, cannot be resorted to, to prove that these words of the constitution are to be construed, not according to their natural import, but that an artificial meaning, drawn from the statute and common law of England, is to be affixed to them, entirely different.

See also id at 139 (argument of opposing counsel) (agreeing that "in the exposition of the constitution artificial rules ought not to be admitted," and "we must be governed by the general principles of reason and justice" rather than "by rules borrowed from the most complicated of all artificial systems on the face of the earth, the common law").

212 See notes 32-33 and accompanying text. See also David P. Currie, The Constitution in Congress: The Federalist Period, 1789-1801 36 (Chicago 1997) (calling this debate "[t]he greatest and best known struggle in the First Congress over the structure of government").

213 The principal alternative to this view was that the Constitution addressed this issue only through the Necessary and Proper Clause, which empowered Congress to pass ordinary statutes giving the President whatever removal power Congress wanted him to have. See, for example, The Congressional Register (May 19, 1789), reprinted in Bickford, Bowling, and Veit, eds, 10 Documentary History of the First Congress 722, 733 (cited in note 94) (remarks of Rep John Laurance); The Congressional Register (June 22,1789), reprinted in Bickford, Bowling, and Veit, eds, 11 Documentary History of the First Congress 1028, 1034-35 (cited in note 24) (remarks of Rep Thomas Tudor Tucker). 
maintained that just as the President could appoint principal executive officers by and with the advice and consent of the Senate, ${ }^{214}$ so too the President could remove them-but only by and with the advice and consent of the Senate. According to these people, practice before the Constitution's adoption had established a default rule that "the power which appoints can also remove, unless there are express exceptions made." ${ }^{215}$ A group led by James Madison, however, rejected this claim in favor of "another maxim which ought to direct us in expounding the constitution." ${ }^{216}$ Founding-era political theory taught that "the great departments of government" should be blended only "under special restrictions and guards," and Madison argued that the text and structure of the Constitution reflected this principle. For Madison, it followed that "we ought to construe the instrument in such a manner as to confound [the legislative and executive departments] as little as possible." While the Constitution had blended the departments' powers with respect to appointment, it had not specified any such mixture of functions with respect to removal, and Madison concluded that it should therefore be understood to vest the power to remove executive officers in the President alone. ${ }^{217}$

Competing interpretive principles played a similarly central role in the debates over whether the First Congress could create a national bank. Because the Constitution did not specifically authorize Congress to create a bank or to charter a corporation, the key question was whether the Necessary and Proper Clause conferred this authority as an incident to the other enumerated powers. Again trying to derive appropriate interpretive approaches from the Constitution itself, Madison concluded that it did not; in his view, the Constitution's own spirit condemned the "latitude of interpretation" on which the bank bill rested. ${ }^{218}$ Madison supported this argument by pointing to the Constitution's careful list of enumerated powers, which included various powers that might not have needed to be specified if the Necessary and Proper Clause were read as broadly as the bank's supporters wanted. ${ }^{219}$ Madison conceded that constitutional interpreters should

214 See US Const Art 1I, $\S 2, \mathrm{cl} 2$.

215 Congressional Register (June 17, 1789) at 917 (cited in note 33) (remarks of Rep Roger Sherman). See also Congressional Register (May 19, 1789) at 729, 732, 737 (cited in note 213) (remarks of Reps Theodorick Bland, James Jackson, and Samuel Livermore) (echoing this view of the removal power).

216 Daily Advertiser (June 22, 1789) at 896 (cited in note 24).

217 Id at 896-97. See also Congressional Register (June 18, 1789) at 963-64, 966 (cited in note 32) (similar remarks of Reps Richard Bland Lee and Elias Boudinot); The Congressional Register (June 19,1789), reprinted in Bickford, Bowling, and Veit, eds, 11 Documentary History of the First Congress 999, 1003-04 (cited in note 24) (similar remarks of Rep Abraham Baldwin). 218 Gazette of the United States (Feb 23, 1791), reprinted in diGiacomantonio, et al, eds, 14 Documentary History of the First Congress 367,372 (cited in note 151) (remarks of Feb 2, 1791).

219 For instance, Congress's power to "make Rules for the Government and Regulation of 
not rely too heavily upon the presumption against surplusage; no "human work" - and particularly not "the work of a body of men"reflected "systematic attention" to "every insertion or omission," and some superfluities were inevitable in a document like the Constitution. ${ }^{200}$ Still, he maintained that the provisions he had cited, when taken together, "sufficiently inculcate [] a rule of interpretation[] very different from that on which the bill rests." According to Madison, "[t]hey condemn the exercise of any power, particularly a great and important power, which is not evidently and necessarily involved in an express power.",221

Madison also set forth five more general rules that he proposed as "preliminaries to a right interpretation" of the Constitution. In the context of the bank debate, the fifth of these rules did the most work. It asserted that "[i]n admitting or rejecting a constructive authority," interpreters should consider "not only the degree of its incidentality to an express authority" but also "the degree of its importance," because "on this will depend the probability or improbability of its being left to construction."2n

Supporters of the bank took various tacks in response to Madison's proposed rules of interpretation. Theodore Sedgwick and Fisher Ames argued that "the purposes for which [the Constitution] was framed" cut against Madison's approach. ${ }^{2.3}$ Elbridge Gerry, by contrast, suggested a more general opposition to interpretive rules that were "made for the occasion" and "not sanctioned by law exposition, or approved by experienced judges of the law." Instead of treating the

the land and naval Forces" might have been deemed incidental to its powers to "raise and support Armies" and "provide and maintain a Navy," which in turn might have been deemed incidental to the power to "declare War." See id (referring to US Const Art I, § 8, cls 11-13). Likewise, Congress's power "[t]o provide for the Punishment of counterfeiting the ... current Coin of the United States" might have been deemed incidental to the power "[t]o coin Money [and] regulate the Value thereof." See id (referring to US Const Art I, § 8, cls 5-6). Even Congress's power " $[\mathrm{t}$ ] borrow money on the credit of the United States" might have been deemed incidental to some of the same powers that were said to justify the creation of the bank. See id (referring to US Const Art I, $\S 8, \mathrm{cl} 2$ ).

220 Id at 372-73.

221 Id at 373. Contrast United States $v$ Lopez, 514 US 549, 588-89 (1995) (Thomas concurring) (making similar use of the presumption against surplusage), with Story, 1 Commentaries $\S 449$ at $435-36$ (cited in note 84 ) (rejecting Madison's approach and arguing that in a document like the Constitution, "the natural import of a single clause is not to be narrowed, so as to exclude implied powers resulting from its character, simply because there is another clause, which enumerates certain powers, which might otherwise be deemed implied powers within its scope").

222 Gazette (Feb 23, 1791) at 369 (cited in note 218).

223 Gazette of the United States (Feb 26, 1791), reprinted in diGiacomantonio, et al, eds, 14 Documentary History of the First Congress 390, 393 (cited in note 151) (remarks of Rep Ames on Feb 3, 1791). See also Gazette of the United States (Mar 5, 1791), reprinted in diGiacomantonio, et al, eds, 14 Documentary History of the First Congress 398, 399 (cited in note 151) (remarks of Rep Sedgwick on Feb 4, 1791) (invoking "the great purposes for which the constitution was designed"). 
Constitution as sui generis, Gerry advocated reliance upon the rules described in Blackstone's Commentaries for the interpretation of statutes. $^{224}$

Even if one construed the Constitution like a statute, though, later years witnessed debates about exactly what sort of statute one should have in mind. The rules that governed penal statutes seemed plainly inapplicable. ${ }^{225}$ But some judges also worried about applying "the latitudinarian rules by which remedial statutes are construed." Similarly, people debated the extent to which notions of equitable construction applied to "a constitution where every word and sentence was the subject of critical examination, and great deliberation." ${ }^{227}$

Statutes, moreover, were not the only sort of legal document to which the Constitution could be analogized. Throughout the antebellum period, it was common to argue that at least some provisions of the Constitution-especially provisions addressing relationships among the states or allocating power to the federal governmentshould be interpreted like the provisions of a treaty or compact. ${ }^{228}$ The accompanying rules of construction potentially had far-reaching consequences. Writing in 1803, for instance, St. George Tucker argued that to the extent the Constitution was a compact among the states, "it is to be construed strictly[] in all cases where the antecedent rights of a state may be drawn in question"; to the extent it was a compact among

224 See The General Advertiser (Mar 3, 1791), reprinted in diGiacomantonio, et al, eds, 14 Documentary History of the First Congress 452, 452-53 (cited in note 151) (remarks of Rep Elbridge Gerry on Feb 7,1791) (invoking Blackstone, 1 Commentaries at 59-61 (cited in note 79)).

225 See, for example, M'Clarin, 11 SCL (2 Nott \& McCord) at *520 ("Subject [the Constitution] to the rules which govern penal statutes, and its active energy, if not its vital principle, must be destroyed."). Compare Opinion of the Justices of the Supreme Judicial Court on the Constitutional Question of Filling Vacancies in the Council, 14 Mass 470, 471 (1784) ("We are certainly to construe the [state] constitution beneficially, in favor of the people of the government, for whose benefit it was made: and not in the nature of a penal statute, which is to be construed strictly.").

226 M'Clarin, 11 SCL (2 Nott \& McCord) at *520.

227 Sturges $v$ Crowninshield, 17 US (4 Wheat) 122, 133 (1819) (argument of counsel). See also William Johnson, Note on the Exposition of the Phrase, "Ex Post Facto," in the Constitution of the United States, in 27 US (2 Pet) 416 app, 416e (1829) (suggesting that "there could be no objection" to using equitable construction to extend the application of the Contracts Clause "if we were construing a statute," but expressing "serious doubt" about "whether this latitude of construction can be safely and on principle applied to the constitution"); Town of Pawlet $v$ Clark, 13 US (9 Cranch) 292, 320 (1815) (argument of counsel) (denying that any "equitable construction" was necessary to reach the position favored by counsel). See generally notes 188-94 and accompanying text (discussing equitable construction).

228 See, for example, Chisholm v Georgia, 2 US (2 Dall) 419, 449 (1793) (Iredell dissenting) (observing that the "conventional" law of nations, which deals with treaties, may "furnish[] rules of interpretation" for the Constitution); Respublica $v$ Cobbet, 3 US (3 Dall) 467, 473 (Pa 1798) (McKean) (asserting that in some respects "the constitution of the United States ... is a league or treaty, made by the individual States, as one party, and all the states, as another party"); "Algernon Sidney" [Spencer Roane], On the Lottery Decision, No 2, Richmond Enquirer 2, 3 (May 29,1821 ) (echoing this characterization of the Constitution, and invoking rules of construction from Vattel's treatise on the law of nations). 
the people, "it ought likewise to receive the same strict construction, wherever the right of personal liberty, of personal security, or of private property may become the subject of dispute. ${ }^{, 29}$ Tucker supported these claims with citations to rules for the interpretation of treaties, including the "maxim of political law" that "sovereign states cannot be deprived of any of their rights by implication." ${ }^{30}$

Supporters of stronger national powers, by contrast, rejected this line of analysis and the accompanying rules of construction. According to Joseph Story, the federal Constitution was no more a treaty than the state constitutions were; like the state constitutions, it was "established by the people for their own purposes," and it should be construed in light of those purposes. ${ }^{231}$ Story argued that while Tucker's rule of "strict construction" made perfect sense for instruments that granted powers "to a monarch, for his own benefit and use," it had no application to "a constitution of government, framed by the people for their own benefit and protection.",22

Thus far, we have identified early support for at least four different approaches to constitutional interpretation: (1) reading the Constitution as a layman might, (2) deriving special canons of construction from the Constitution's unique nature and purpose, (3) borrowing preexisting rules for the interpretation of statutes, and (4) borrowing preexisting rules for the interpretation of treaties or compacts. This list, though, does not exhaust the possibilities that were available to members of the founding generation. Among other things, different approaches could be combined in a variety of different ways. Thus, the great Vermont jurist Nathaniel Chipman favored an eclectic mix of rules of construction, drawn partly from the common law (with its

229 St. George Tucker, 1 Blackstone's Commentaries: with Notes of Reference, to the Constitution and Laws, of the Federal Government of the United States; and of the Commonwealth of Virginia app D at 151 (Lawbook Exchange 1996) (originally published 1803). See also id at 154 (concluding that "the powers delegated to the federal government, are, in all cases, to receive the most strict construction that the instrument will bear, where the rights of a state or of the people, either collectively, or individually, may be drawn in question"); Gibbons $v$ Ogden, 22 US ( 9 Wheat) 1,87 (1824) (argument of counsel) ("This rule of construction must be correct ....").

230 Tucker, 1 Blackstone's Commentaries app D at 143, 151 (cited in note 229). Accord, for example, People v Godfrey, 17 Johns 225, 232 (NY Sup Ct 1819). Compare Craig v Missouri, 29 US (4 Pet) 410,421 (1830) (argument of counsel) ("The language of the constitution [forbidding states to 'emit Bills of Credit'] should be strictly construed; as it is a limitation on the sovereignty of a state."); Federalist 32 (Hamilton), in The Federalist 199, 202 (cited in note 26) (indicating that only "an immediate constitutional repugnancy," and not "a mere possibility of inconvenience in the exercise of powers," can "by implication alienate and extinguish a pre-existing right of sovereignty" enjoyed by the states).

231 Story, 1 Commentaries $\$ 409$ at 393 (cited in note 84 ).

232 Id $\S 413$ at 396 . See also Gibbons, 22 US ( 9 Wheat) at 188-89 (rejecting counsel's call for "strict construction" and indicating that uncertainties about "the extent of any given power" should instead be resolved in light of "the objects for which [the power] was given, especially when those objects are expressed in the instrument itself"). 
rules for the interpretation of statutes), partly from the law of nations (with its rules for the interpretation of treaties), partly from the Constitution itself, and partly from the "general end and design" of the system that the Constitution erected. ${ }^{23}$ The possibility of such combinations only multiplies the number of different interpretive regimes that could reasonably be applied to the Constitution.

A further complication sprang from the nature of the interpretive questions that the Constitution presented. As we have seen, courts and commentators had built up various sets of default rules to handle questions that often arose in the interpretation of statutes, contracts, deeds, and other familiar sorts of legal documents. ${ }^{24}$ But even if one were willing to analogize the Constitution to one or another of these sorts of documents, practice under the Constitution inevitably raised some novel questions-questions that did not regularly come up under ordinary laws or contracts, and for which default rules therefore had not developed. The result, again, was a more unsettled interpretive background than people were used to confronting.

Antebellum commentators were fully aware of these problems. Indeed, they attached considerable importance to disputes about which rules of interpretation the Constitution implicated. In his 1833 treatise on constitutional law, Justice Story concluded that "[m]uch of the difficulty" reflected in the preceding half-century of disagreements about the Constitution's meaning "has had its origin in the want of some uniform rules of interpretation, expressly or tacitly agreed on by the disputants." ${ }^{\text {,23 }}$ Nathaniel Chipman likewise asserted that one could not "attain even a general understanding of the constitution" without first recognizing the proper rules of construction. ${ }^{236}$ Other jurists of the day bemoaned the fact that uncertainty about the applicable rules of construction left judges with an unusual amount of interpretive discretion. ${ }^{237}$

To the extent that founding-era Americans could plausibly have invoked a variety of different rules of construction to answer the questions that the Constitution raised, originalists face a potential problem. The Constitution's "original meaning," like the meaning of any legal document, depends upon the applicable interpretive conventions. Because of the Constitution's novelty, though, the range of conventions

233 Chipman, Principles of Government at 253 (cited in note 83) (asserting that the proper rules for interpreting the Constitution "are to be derived from various sources").

234 See notes 173-86 and accompanying text (providing examples).

235 Story, 1 Commentaries $\$ 398$ at 383 (cited in note 84 ).

236 Chipman, Principles of Government at 253 (cited in note 83). See also Henry Wheaton, Elements of International Law: With a Sketch of the History of the Science 204 (Carey, Lea, \& Blanchard 1836) (asserting that "the mere words alone of any writing, literally expounded, will go a very little way towards explaining its meaning").

237 See M'Clarin, 11 SCL (2 Nott \& McCord) at *520-21. 
that might apply was broad. This uncertainty makes the document's "original meaning" less determinate than originalists sometimes suggest.

\section{A Way Out? The Example of the Ex Post Facto Clauses}

This extra source of indeterminacy does not defeat originalism; originalists certainly do not have to abandon their approach simply because it sometimes will identify only a range of "original meanings. ${ }^{228}$. Indeed, Professor Whittington argues that originalism's capacity to accommodate textual indeterminacy is one of its advantages. ${ }^{239}$

Still, some originalists will not be eager to acknowledge more indeterminacy than necessary. For originalists who seek determinacy, the founding generation's uncertainty about the interpretive conventions applicable to the Constitution is troublesome. But just as an investigation of founding-era rules of construction alerts us to this problem, so too it suggests a possible solution. In particular, the process of "liquidation" can help resolve doubts about appropriate interpretive techniques at the same time that it settles the meaning of individual words.

For a simple example, consider the Constitution's Ex Post Facto Clauses, which disable both the federal government and the states from passing any "ex post facto Law." meaning of this prohibition arguably depended on whether one read the key phrase as a lawyer or as a layperson. To the lay public, any law that operated retrospectively could be described as an "ex post facto Law. ${ }^{241}$ Among lawyers, by contrast, the phrase sometimes was a term of art that referred only to penal or criminal laws; Blackstone arguably used the phrase in this way, ${ }^{242}$ and at least two state constitutions followed his lead. ${ }^{243}$

238 See Gary Lawson, Delegation and Original Meaning, 88 Va L Rev 327, 338 n 43, 340 n 47 (2002) (debunking the idea, common among nonoriginalists, that originalism assumes a fully determinate original meaning).

239 See Whittington, Constitutional Interpretation at 206 (cited in note 11) ("An important contribution of originalism is that it highlights the indeterminacies in the text as well as illuminating and enforcing its known requirements. In doing so, originalism points out the space for future constitutional development, without asserting judicial supremacy in determining the shape of that development.").

240 US Const Art I, $\S 9$ (federal government); Art I, $\$ 10$ (states).

241 See, for example, William Winslow Crosskey, 1 Politics and the Constitution in the History of the United States 325-29 (Chicago 1953) (citing examples of this usage in newspapers from the $1780 \mathrm{~s}$, and arguing that this usage was common among lawyers too). Of course, determining whether a law operates "retrospectively" is not as simple as it might sound. See, for example, DeCordova $v$ City of Galveston, 4 Tex 470, 479-80 (1849) (concluding that the Texas constitution's prohibition on "retrospective" laws did not cover laws that merely affect the remedy for existing rights, "unless the remedy be taken away altogether or encumbered with conditions that would render it useless or impracticable to pursue it").

242 See Blackstone, 1 Commentaries at 46 (cited in note 79) (referring to the "unreasonable method ... called making of laws ex post facto; when after an action is committed, the legislator 
The ratification debates featured some sustained discussion about which perspective interpreters would adopt. At the Virginia convention, opponents of the Constitution portrayed the Ex Post Facto Clauses as ill-advisedly prohibiting all retrospective legislation..$^{24}$ In response, Edmund Randolph emphasized that "[e]x post facto laws, if taken technically, relate solely to criminal cases,",45 and James Madison

then for the first time declares it to have been a crime, and inflicts a punishment upon the person who has committed it").

243 See Md Const of 1776, Decl of Rights, Art 15 ("[R]etrospective laws, punishing facts committed before the existence of such laws, and by them only declared criminal, are oppressive, unjust, and incompatible with liberty; wherefore no ex post facto law ought to be made."), reprinted in William F. Swindler, ed, 4 Sources and Documents of United States Constitutions 372, 373 (Oceana 1975); NC Const of 1776, Decl of Rights, Art 24 (same), reprinted in William F. Swindler, ed, 7 Sources and Documents of United States Constitutions 402, 403 (Oceana 1978). See also Tenn Const of 1796, Art XI, $\$ 11$ (declaring that "laws made for the punishment of facts committed previous to the existence of such laws, and by them only declared criminal, are contrary to the principles of a free government; wherefore no ex post facto law shall be made"), reprinted in William F. Swindler, ed, 9 Sources and Documents of United States Constitutions 141, 148 (Oceana 1979).

Professor Crosskey is correct, however, that even lawyers sometimes used the phrase "ex post facto law" more broadly. See, for example, Warder v Arell, 2 Va (2 Wash) 282, 290 (1796) (argument of counsel) ("[I]f the Act of May 1778 repeals the third section of the Act of January 1777 , great injustice would follow. It would operate as an ex post facto law, as to those, who, after January 1777 , may have sold their estates on credit, under an expectation of being able with the money to discharge the debt they owed."); Hull v Minor, 2 Root 223, 223 (Conn Super Ct 1795) (concluding that a statute of limitations enacted in 1788 did not cover a cause of action on a note issued in 1777, and adding that even if the note were within the letter of the statute, "the statute [still] would not affect it, being an ex post facto law"); Kissam v Burrall, 1 Kirby 326, 332-33 (Conn Super Ct 1787) (argument of counsel) (asserting that if a rule adopted in 1784 for computing interest were applied to bonds entered into before 1784, it would be "an ex post facto law"); Remonstrance of the New Hampshire Legislature (Feb 20, 1794), in Maeva Marcus, ed, 6 The Documentary History of the Supreme Court of the United States, 1789-1800 400, 401 (Columbia 1998) ("The States are forbidden by the Federal Constitution, to make any retrospective laws."). See also Stoddart v Smith, 5 Binn 355, 370 (Pa 1812) (Brackenridge) (arguing that the notion that the phrase "ex post facto law" refers only to crimes "is an idea purely American" and "is incorrect"); Wilkinson v Meyer, 92 Eng Rep 379, 380 (KB 1724) (Raymond) (using the label "ex post facto" to describe a statute that required the registration of certain preexisting contracts and that made unregistered contracts void).

244 See Debates in the Virginia Convention (June 17, 1788) at 1355 (cited in note 112) (reporting George Mason's argument that the Ex Post Facto Clauses would prevent Congress and the state legislatures from passing laws recognizing the depreciation of past emissions of paper money); id at 1346, 1356-57 (reporting Patrick Henry's argument to the same effect). AntiFederalists in other states expressed similar views. See, for example, Centinel XVI, Philadelphia Independent Gazetteer (Feb 26, 1788), reprinted in Kaminski and Saladino, eds, 16 Documentary History of the Ratification at 217,218 (cited in note 40) (arguing that because the Constitution barred all laws "made after the fact," the new Congress would be unable to do anything about people who were already in default on public debts, and "the unaccounted millions lying in their hands would become their private property").

245 Debates in the Virginia Convention (June 17,1788) at 1359 (cited in note 112). See also Federalist 84 (Hamilton), in The Federalist 575, 577 (cited in note 26) (discussing the Constitution's "prohibition of ex post facto laws" solely in terms of "[t] commission of the fact"). Elsewhere, some supporters of the Constitution seemed to take a broader view of the Ex Post Facto Clauses. See, for example, George Nicholas, Untitled Manuscript (Feb 16, 1788), in John P. Kaminski and Gaspare J. Saladino, eds, 8 The Documentary His- 


\section{apparently said that the phrase had been so interpreted at the Phila- delphia Convention. ${ }^{246}$ The Anti-Federalist George Mason replied that}

tory of the Ratification of the Constitution 369, 371 (State Historical Society of Wisconsin 1988) (arguing, in support of the Constitution, that the Ex Post Facto Clauses would prevent both Congress and the state legislatures from emancipating the slaves or otherwise "pass[ing] an act to deprive any man or set of men of property which they hold under the general laws of the land"); Justus Dwight Journal (Jan 29, 1788), in John P. Kaminski and Gaspare J. Saladino, eds, 7 The Documentary History of the Ratification of the Constitution 1799, 1816 (State Historical Society of Wisconsin 2001) (indicating that at the Massachusetts ratifying convention, Theodore Sedgwick argued that Congress would be unable to subject states to suit by existing bond-holders from other states because "that will come under the Ex post facto Law"); One of the MiddlingInterest, Some Objections to the New Constitution Considered, Mass Centinel (Nov 28, 1787), reprinted in John P. Kaminski and Gaspare J. Saladino, eds, 4 The Documentary History of the Ratification of the Constitution 328, 330 (State Historical Society of Wisconsin 1997):

The 24th article of our own state bill of rights declares ... that laws made to punish for actions done before the existence of such laws, \&c. are unjust. This relates then to ex post facto laws in criminal prosecutions: But our state bill of rights is silent as to any ex post facto laws which relate to property, and civil prosecutions; though it must be confessed that such laws are as much against the nature of government as those relating to crimes. The federal constitution has accordingly guarded against such laws, and clearly, because some states, of which our own is one, have not observed such a restriction.

246 Debates in the Virginia Convention (June 17, 1788) at 1359, $1370 \mathrm{n} 15$ (cited in note 112). The records of the Philadelphia Convention paint a somewhat more complicated picture. At first, members of the Convention seemed to assume that the phrase "ex post facto Law" covered all retrospective laws. Thus, when Rufus King moved to add a prohibition against state laws that interfered with preexisting private contracts, James Madison and John Rutledge assumed that a ban on "ex post facto laws" would take care of King's concerns. See Max Farrand, ed, 2 The Records of the Federal Convention of 1787 439-40 (Yale 1966). According to Madison's notes, however, John Dickinson subsequently "mentioned to the [Convention] that on examining Blackstone's Commentaries, he found that the terms 'ex post facto' related to criminal cases only; that they would not consequently restrain the States from retrospective laws in civil cases, and that some further provision for this purpose would be requisite." Id at 448-49.

It is unclear exactly how the Convention received Dickinson's comment. The Convention made no relevant changes before September 8,1787 , when it referred the provisions that it had approved to the Committee of Style for polishing and rearrangement. But the Committee of Style added what became the Contracts Clause of Article I: In addition to prohibiting both states and the federal government from passing "ex post facto Law[s]," the Constitution also forbids states to "pass any ... Law impairing the Obligation of Contracts." US Const Art I, $\$ 10$. The addition of this provision might suggest that the Convention understood the Ex Post Facto Clauses narrowly. See, for example, Calder v Bull, 3 US (3 Dall) 386, 397 (1798) (Paterson) (arguing that if the Ex Post Facto Clause already prohibited all retrospective legislation, then the Contracts Clause would be superfluous). This argument is not bulletproof, however, because the meaning of the Contracts Clause was itself open to dispute; unlike its predecessor in the Northwest Ordinance, its terms were not limited to contracts "previously formed," and so it could plausibly be read to prohibit even prospective impairments of contracts. See Ogden v Saunders, 25 US (12 Wheat) 213, 332-57 (1827) (Marshall dissenting) (advocating this reading of the Contracts Clause); Max Farrand, ed, 4 The Records of the Federal Convention of 178759 (Yale 1937) (reflecting George Mason's unsuccessful motion at the Philadelphia Convention to insert the word "previous" before "contracts"). Compare An Ordinance for the Government of the Territory of the United States north-west of the river Ohio, Art II (1787), reprinted in 1 Stat $51 \mathrm{n}$ (a), 52 (declaring that "no law ought ever to be made, or have force in the said territory, that shall in any manner whatever interfere with, or affect private contracts or engagements, bona fide, and without fraud, previously formed").

Motions made after the Committee of Style produced its draft reflect continuing uncertainty 
reliance on "technical definitions" was misplaced: The meaning of the phrase "ex post facto Law" in the Constitution depended upon its import to the common citizen, not to lawyers steeped in Blackstone. ${ }^{24}$ Randolph countered with further observations about the phrase's "technical meaning"; ${ }^{248}$ Mason remained unconvinced that this meaning governed. ${ }^{249}$

The New York ratifying convention appears to have wrestled with similar questions. In New York, however, the convention as a whole took an official position on how to approach the Ex Post Facto Clauses. Its ratification instrument offered various "explanations" of the Constitution, including the assertion "[t]hat the prohibition contained in the said Constitution against ex post facto laws, extends only to laws concerning crimes.",250

Members of the Supreme Court adopted the same view when the question reached them in the 1798 case of Calder $v$ Bull. $^{251}$ Justice Paterson, who had been a member of the Philadelphia Convention, asserted that he had "ardent[ly]" wanted to "extend[] the provision in the Constitution to retrospective laws in general," but he concluded that "[t]he words ex post facto, when applied to a law, have a technical meaning, and, in legal phraseology, refer to crimes, pains, and penalties." ${ }^{252}$ Justice Chase likewise maintained that "[t]he expressions ' $e x$ post facto laws,' are technical[;] they had been in use long before the revolution, and had acquired an appropriate meaning, by legislators, lawyers, and authors." ${ }^{233}$ Even Justice Iredell, who had earlier sug-

about the meaning of the Ex Post Facto Clauses. By this point, Madison himself seems to have accepted the technical reading. But on September 14, George Mason called for reconsideration or omission of the prohibitions on "ex post facto law[s]." According to Madison's notes, Mason "thought it not sufficiently clear that the prohibition meant by this phrase was limited to cases of a criminal nature." Farrand, ed, 2 Records of the Federal Convention at 617 . Elbridge Gerry also supported modification of the "ex post facto" language, but for the opposite reason; Gerry wanted the prohibition to cover civil cases. See id. Faced with these conflicting calls for revision or clarification, the Convention left the relevant language unchanged.

247 Debates in the Virginia Convention (June 17,1788) at 1361 (cited in note 112).

248 See id at 1363 (reporting Randolph's claim that "[t]he technical meaning which confined such laws solely to criminal cases, was followed in the interpretation of treaties between nations, and was concurred in by all civilians").

249 See Debates in the Virginia Convention (June 19, 1788), in Kaminski and Saladino, eds, 10 Documentary History of the Ratification 1387, 1408 (cited in note 24) (arguing that the Ex Post Facto Clause would call into question a salutary 1779 statute purporting to confirm titles to western lands).

250 Declaration of Rights and Form of Ratification (July 26, 1788), in John P. Kaminski and Gaspare J. Saladino, eds, 18 The Documentary History of the Ratification of the Constitution 297, 300 (State Historical Society of Wisconsin 1995).

2513 US (3 Dall) 386.

252 Id at 396 (Paterson). Compare id at 397 (suggesting that this "technical" understanding of the words "ex post facto laws" coincided with "their common and general[] acceptation," although it diverged from "their literal sense").

253 Id at 391 (Chase). See also id at 390: 
gested a broader understanding of the Ex Post Facto Clauses, ${ }^{254}$ agreed that "the true construction of the prohibition extends to criminal, not to civil, cases." ${ }^{255}$ Of the four Justices who delivered opinions in Calder, only William Cushing expressed no position on this issue. ${ }^{256}$

Over time, legislative and judicial precedents supporting the narrow reading of the Ex Post Facto Clauses continued to accumulate. ${ }^{257}$ In the late 1820s, Supreme Court Justice William Johnson did urge his colleagues to reexamine their understanding of the Clauses; he criti-

I will state what laws I consider ex post facto laws, within the words and the intent of the prohibition. 1st. Every law that makes an action done before the passing of the law, and which was innocent when done, criminal; and punishes such action. $2 \mathrm{~d}$. Every law that aggravates a crime, or makes it greater than it was, when committed. 3d. Every law that changes the punishment, and inflicts a greater punishment, than the law annexed to the crime, when committed. 4th. Every law that alters the legal rules of evidence, and receives less, or different, testimony, than the law required at the time of the commission of the offence, in order to convict the offender.

254 See Marcus I (Iredell), Norfolk and Portsmouth J (Feb 20, 1788), reprinted in Kaminski and Saladino, eds, 16 Documentary History of the Ratification 161, 164 (cited in note 40) ("The people are expressly secured (contrary to Mr. Mason's wishes) against ex post facto laws, so that the tenure of any property at any time held under the principles of the common law, cannot be altered by any act of the future general legislature.").

255 Calder, 3 US at 399 (Iredell). By "criminal" laws, Justice Iredell and his colleagues may simply have meant laws that defined offenses and imposed punishments for them. Thus, penal statutes might come within the ambit of the Ex Post Facto Clauses even though the penalties that they prescribed could be collected through civil suits. See id at 400 (Iredell) (saying that the Ex Post Facto Clauses prevent Congress and the state legislatures from "inflict[ing] a punishment for any act, which was innocent at the time it was committed"); id at 397 (Paterson) (indicating that the Ex Post Facto Clauses reach "the creation of a crime or penalty") (emphasis added); id at 390 (Chase) ("[T]he plain and obvious meaning and intention of the prohibition is this: that the legislatures of the several states, shall not pass laws, after a fact done by a subject, or citizen, which shall have relation to such fact, and shall punish him for having done it.") (emphasis omitted). Compare note 191 and accompanying text (discussing penal statutes).

256 See Calder, 3 US at 400-01 (Cushing). See also Minge v Gilmour, 17 F Cas 440, 443 (CCD NC 1798) (Iredell) (noting that at oral argument in Calder "[a] majority of the judges appeared to be convinced" of the "technical[]" meaning of the Ex Post Facto Clauses, but that "upon the doubt of one" the case had not yet been decided).

257 See, for example, Satterlee v Matthewson, 27 US (2 Pet) 380, 413 (1829) ("[R]etrospective laws which do not impair the obligation of contracts, or partake of the character of ex post facto laws, are not condemned or forbidden ...."); Warden of Bridgeport v Hubbell, 5 Conn 237, 240 (1824) ("An act ex post facto relates to crimes only; ... the expression is never applicable to a law creating a civil obligation."); Strong $v$ State, 1 Blackf *193, *196 (Ind 1822):

The words ex post facto have a definite, technical signification. The plain and obvious meaning of this prohibition [in the state constitution] is, that the Legislature shall not pass any law, after a fact done by any citizen, which shall have relation to that fact, so as to punish that which was innocent when done; or to add to the punishment of that which was criminal; or to increase the malignity of a crime; or to retrench the rules of evidence, so as to make conviction more easy.

See also Fowler $v$ Halbert, $7 \mathrm{Ky}$ (4 Bibb) 52, 56 (1815) (Owsley) ("[T]he uniform opinion of judges, both ancient and modern, confine[s] th[e] import [of the phrase 'ex post facto law'] to crimes, pains and penalties."); Byrne's Administrators $v$ Stewart's Administrators, 3 SC Eq (3 Des) 466, 477 (Ct Ch 1812) (Waties) ("It appears from the best authorities, that the words ex post facto, when applied to a law refer only to crimes and penalties."). 
cized the "unhappy idea" that "the phrase 'ex post facto,' in the constitution of the United States, was confined to criminal cases exclusively, ${ }^{328}$ and he published a detailed essay advancing the contrary view. $^{239}$ By this time, however, most observers believed that years of consistent interpretation had fixed the Clauses' meaning on this point, even though Justice Johnson's position might have been equally plausible at the start. As Joseph Story put it in his 1833 Commentaries on the Constitution, "the current of opinion and authority has been so generally one way, as to the meaning of this phrase in the state constitutions, as well as in that of the United States, ever since their adoption, that it is difficult to feel, that it is now an open question., ${ }^{250}$ In support of this proposition, Justice Story cited not only Calder v Bull and its progeny, but also the records of the Philadelphia Convention and the ratification debates. ${ }^{261}$

We can draw several lessons from the saga of the Ex Post Facto Clauses. Most obviously, the Clauses illustrate how a consistent course of interpretation could help to "fix" the meaning of provisions that were indeterminate when they emerged from the Philadelphia Convention. But the Clauses also illustrate how practice could help settle upon appropriate methods of constitutional interpretation. At the outset, it was not entirely clear whether all of the Constitution's provisions should be given their lay meaning, or whether some provisions could legitimately be treated as technical terms of art. ${ }^{262}$ Early interpretations of the Ex Post Facto Clauses helped establish the legitimacy of reading at least some provisions of the Constitution in a technical rather than lay sense.

The history of the Ex Post Facto Clauses also illustrates the ripple effects that can accompany the resolution of constitutional indeterminacies. When the Constitution emerged from the Philadelphia Convention, both the Ex Post Facto Clauses and the Contracts Clause had a range of possible meanings. ${ }^{263}$ Ultimately, the Ex Post Facto Clauses were limited to the penal domain, and the Contracts Clause was read to prohibit only retrospective impairments of contracts. But if the inde-

258 Satterlee, 27 US (2 Pet) at 416 (Johnson concurring in the judgment). Accord Ogden v Saunders, 25 US (12 Wheat) at 286 (separate opinion of Johnson) (denying "that the phrase 'ex post facto,' was confined to laws affecting criminal acts alone").

259 Johnson, Note on the Exposition of the Phrase "Ex Post Facto" at 416a-416e (cited in note 227).

260 Joseph Story, 3 Commentaries on the Constitution of the United States $\$ 1339$ at 212 (Hilliard, Gray 1833). See also City of Bridgeport v Housatonuc Railroad Co, 15 Conn *475, *496 (1843) (indicating that legislation and court decisions had "spoken too frequently and too explicitly" upon the question "to be disregarded at this day"); Martindale v Moore, 3 Blackf *275, *278

(Ind 1833) (Stevens) (agreeing that the issue is "settled").

261 See Story, 3 Commentaries $\S 1339$ at 212 n 2 (cited in note 260 ).

262 See notes $244-49$ and accompanying text.

263 See note 246. 
terminacies in the Ex Post Facto Clauses had been resolved differently -if the phrase "ex post facto Law" had been understood to encompass all retrospective laws - then the meaning of the Contracts Clause might also have been fixed differently. After all, if the Ex Post Facto Clause broadly prohibited retrospective legislation, then the Contracts Clause would be superfluous unless it prohibited prospective impairments of contracts. Given the presumption against surplusage, a different resolution of the indeterminacy in the Ex Post Facto Clauses might have encouraged a different resolution of the indeterminacy in the Contracts Clause too.

For our purposes, the most important lesson to draw from the history of the Ex Post Facto Clauses is simple. Modern-day originalists sometimes speak as if their only project is to determine the meaning of the Constitution at the moment of the framing. They may therefore stand ready to reconsider whether the Ex Post Facto Clauses are limited to the retrospective imposition of punishment; as we have seen, the words "ex post facto Law" could have been read more broadly in $1787 .^{264}$ But originalists who accept the Madisonian concept of "liquidation" will not stop there; they will also consider how subsequent interpretation "fixed" the meaning of the Ex Post Facto Clauses by settling upon one of the permissible understandings. While the internal logic of originalism does not necessarily require all originalists to embrace the concept of liquidation, some originalists may well conclude that this approach offers the best way to handle the unsettled interpretive background against which the Constitution was adopted. ${ }^{265}$

\section{The Legal Effect of the Ratification Debates}

The experience of the Ex Post Facto Clauses also suggests a way for originalists to explain the legal effect of the ratification debates. To date, originalist theory on this point has tended to swing between two extremes. Some writers have suggested that the meaning assigned to constitutional provisions in the state ratifying conventions has dispositive legal weight: The Constitution means whatever its ratifiers understood it to mean, even if their interpretation was objectively unreasonable. ${ }^{266}$ Other writers have concluded that at least in theory, the un-

264 See Eastern Enterprises v Apfel, 524 US 498, 538-39 (1998) (Thomas concurring) (raising this issue).

265 Originalists who embrace the concept of "liquidation" will bridge some (though certainly not all) of the gap that separates originalism from other leading approaches to the Constitution. Indeed, G. Edward White has asserted that the "essential difference" between originalists and other "neohistorian" scholars like Larry Kramer concerns the time span on which they focus; originalist history is "Founding obsessed," while Professor Kramer's history covers "a far broader sweep in time." G. Edward White, The Arrival of History in Constitutional Scholarship, 88 Va L $\operatorname{Rev} 485,629$ n 361 (2002) (quotation marks omitted).

266 See, for example, Kay, $82 \mathrm{Nw}$ U L Rev at 231-32, 247 (cited in note 22) (arguing that 
derstandings reflected in the state ratification debates have no legal weight; records of the ratification debates are relevant only as a kind of dictionary that sheds light on "the general and popular use of constitutional language at the time it was ratified., ${ }^{267}$ But the experience of the Ex Post Facto Clauses suggests an intermediate possibility. Perhaps interpretations acted upon in the state ratifying conventions are best seen as precedents - as events that were not dispositive (at least in isolation), but that could be important steps toward "fixing" the meaning of provisions that were ambiguous when they emerged from Philadelphia. ${ }^{206}$

Originalist attempts simply to equate the Constitution's meaning with the understandings of its ratifiers run into a host of problems. For one thing, this approach has trouble handling disagreements among the ratifiers about the meaning of the Constitution. On some issues, it is hard enough to identify consensus interpretations within a single state's convention. The difficulties are only magnified when one tries to identify consensus interpretations across different states. Because the states had different concerns and different backgrounds, interpretations that prevailed in one state might have been rejected in others. $^{269}$ The debate over the Constitution also went through important changes over the course of the ratification process. ${ }^{270}$ As a result, conventions that ratified the Constitution early on (like Delaware and Pennsylvania) surely viewed the document differently in some respects than conventions that acted later (like Virginia and New York).

"[l]egal obligations arise because we recognize law-making authority vested in certain human beings," that "the lawmaker's intention" is therefore "critical," and that in the case of the Constitution "[t]he inquiry into original intent [ ] should focus on the intentions of the various ratifying bodies who possessed the constituent authority"). See also id at 234-35 (indicating that the theoretical justification for investigating the "ordinary usage [of the Constitution's words] at the time of enactment" is that such usage is generally "[t]he best evidence of the enactors' intent").

267 Office of Legal Policy, Original Meaning Jurisprudence at 9 (cited in note 3). See also id at 15 (observing that statements made by framers and ratifiers about the meaning of particular provisions are not "dispositive in themselves," but can be "highly probative of how the language of the Constitution was understood by the society as a whole").

268 This idea, of course, is not inconsistent with also using the records of the ratifying conventions as one source of evidence about how members of the founding generation used language and about the issues of public concern that formed the background for the Constitution.

269 See Story, 1 Commentaries $\$ 406$ at 388 (cited in note 84 ):

In different states and in different conventions, different and very opposite objections are known to have prevailed; and might well be presumed to prevail. Opposite interpretations, and different explanations of different provisions, may well be presumed to have been presented in different bodies, to remove local objections, or to win local favour.

270 See, for example, Herbert J. Storing, What the Anti-Federalists Were For 32 (Chicago 1981) (discussing "a shift, which occurred gradually and erratically during the ratification debate, in ... the understanding of the American 'federal' system"). 
If the Constitution means whatever its ratifiers understood it to mean, then different conventions arguably ratified different things. ${ }^{271}$

Still, it does not follow that originalists must avoid giving any legal effect to the interpretations acted upon by ratifying conventions. In his treatise on constitutional law, Justice Story acknowledged that such interpretations "must be resorted to with much qualification and reserve." ${ }^{22}$ In a passage that one critic of originalism has called "the definitive rejection of ratifier intent,", ${ }^{273}$ Story referred to " $[t]$ he known diversity of construction of different parts of [the Constitution] ... in the different state conventions," ${ }^{274}$ and he added that "[t]he people adopted the constitution according to the words of the text in their reasonable interpretation" rather than "according to the private interpretation of any particular men., ${ }^{275}$ But while Story was emphatic that interpretations voiced in the ratifying conventions could never "abrogate the text" or "supersede its natural and just interpretation," he was equally clear that they were not meaningless. Among other things, they could help "expound" clauses that were "obscure."

Story's famous opinion in Martin v Hunter's Lessee $e^{27}$ illustrates his sense of the legal effect of the ratification debates. Martin held that the federal Supreme Court can exercise appellate jurisdiction over cases from the state courts. In support of this conclusion, Story referred to positions taken during the ratification debates (along with other early interpretations acted upon by both the courts and Congress) as having helped to "place the doctrine upon a foundation of authority which cannot be shaken, without delivering over the subject to perpetual and irremediable doubts." ${ }^{278}$ For Story, then, the ratification debates were not simply dictionaries that helped show how words and phrases were used at the time of the framing; in addition to serving this function, ${ }^{279}$ they could also provide precedents to help liquidate the meaning of provisions that had initially been open to more than one interpretation.

As with other questions of interpretive method, of course, different early interpreters voiced a variety of different views about the le-

271 See Donald O. Dewey, James Madison Helps Clio Interpret the Constitution, 15 Am J Legal Hist 38,41 (1971) ("Georgia and Virginia and Delaware and New York did not all think alike when in convention assembled.").

272 Story, 1 Commentaries $\$ 406$ at 388-90 (cited in note 84 ).

273 Levy, Original Intent at 15 (cited in note 9).

274 Story, 1 Commentaries $\S 406$ at 389 (cited in note 84).

275 Id $\$ 407 \mathrm{n} 1$ at $390,392$.

276 Id $\$ \S 406-07$ at 390.

27714 US (1 Wheat) 304 (1816).

278 Id at 351-52.

279 See Story, 1 Commentaries $\$ 405$ at 388 (cited in note 84) ("Much [ ] may be gathered from contemporary history, and contemporary interpretation, to aid us in just conclusions."). 
gal effect of interpretations acted upon by the ratifying conventions. At the Virginia ratifying convention, for instance, George Nicholas suggested an approach inspired by his view of contract law; he tried to assure his colleagues that the declarations set forth in Virginia's form of ratification would "become a part of the contract" and that " $t]$ he Constitution cannot be binding on Virginia, but with these conditions., ${ }^{200}$ James Madison himself, while consistently emphasizing the importance of views acted upon by the ratifying conventions, seems to have vacillated between thinking of them in contractarian terms ${ }^{231}$ and thinking of them as a species of precedent. ${ }^{22}$ At the opposite end of the spectrum, some other early interpreters suggested that those views

280 Debates in the Virginia Convention (June 24, 1788), in Kaminski and Saladino, eds, 10 Documentary History of the Ratification at 1473, 1506 (cited in note 24). Nicholas's position may have been influenced by his belief that Virginia's declarations coincided with "what the words of the contract plainly and obviously denote." See id at 1506-07.

281 See, for example, Letter from James Madison to Andrew Stevenson (Mar 25, 1826), in 3 Letters of Madison 520,522 (cited in note 27) (emphasizing that interpretations of the Constitution should not "lose sight of the intention of the parties to it"); Gazette (Feb 23, 1791) at 375 (cited in note 218) (remarks of Rep James Madison on Feb 2,1791) (warning that if Congress established a national bank, people would say "that [the Constitution's] adoption was brought about by one set of arguments, and that it is now administered under the influence of another set"). See also Letter from James Madison to Thomas Ritchie (Sept 15, 1821), in 3 Letters of Madison 228, 228 (cited in note 27):

[T] he legitimate meaning of the Instrument must be derived from the text itself; or if a key is to be sought elsewhere, it must be, not in the opinions or intentions of the body which planned and proposed the Constitution, but in the sense attached to it by the people in their respective State Conventions, where it received all the authority which it possesses.

Compare Letter from James Madison to John G. Jackson (Dec 27, 1821), in 3 Letters of Madison 243,245 (cited in note 27) ("[W]hatever might have been the opinions entertained [by members of the Philadelphia Convention] in forming the Constitution, it was the duty of all to support it in its true meaning, as understood by the nation at the time of its ratification.").

282 See, for example, Letter from Madison to Davis at 244-49 (cited in note 76) (citing views expressed in the Massachusetts ratifying convention, as well as in a litany of subsequent legislative, executive, and judicial decisions, as "authoritative interpretations" that could "settle [the Constitution's] meaning and the intentions of its authors"). Compare 5 Annals of Congress at 737-38 (cited in note 151) (remarks by Rep Albert Gallatin on Mar 24, 1796) (reviewing "contemporaneous expositions" of the Constitution in the ratifying conventions, and then "recur[ring] to the [constitutional text], the meaning of which could perhaps be explained in doubtful cases, but never could be altered or subverted by any opinions or precedents").

There is not necessarily any inconsistency between thinking of interpretations acted upon by the ratifying conventions as a species of precedent and thinking of them in contractarian terms. Interpretations acted upon by the ratifying conventions are supported by "reliance interests" of the sort that doctrines of precedent traditionally emphasize. Compare Nelson, $87 \mathrm{Va} \mathrm{L} \mathrm{Rev} \mathrm{at}$ 20-21, 36-37 (cited in note 86). In addition, doctrines of precedent recognize strength in numbers; to the extent that the various ratifying conventions agreed with each other about the proper understanding of the Constitution, the precedential force of their combined decisions might be extremely powerful. For Madison, though, precedents that stretched back to the founding seem to have had two different kinds of influence; in addition to their legal authority as precedents, they had evidentiary force as indications of what the Constitution's words and phrases had meant to members of the founding society. Thus, in addition to helping settle upon a particular point within the range of permissible interpretations, they could also shed light on what that range was. 
had no legal effect at all. ${ }^{233}$ Thus, even if present-day originalists were determined to follow founding-era ideas about how to handle the ratifying conventions' views, ${ }^{234}$ they would have a menu of ideas to choose from.

Still, the notion that the ratifying conventions' views can help to "fix" the meaning of otherwise ambiguous provisions is one plausible way of giving those views legal effect without getting mired in enormous theoretical problems. The likelihood that different ratifying conventions took somewhat different views of the Constitution does not create any logical crisis for this approach. If the surviving records of the ratifying conventions fail to reveal any consensus about a particular interpretive question, we can simply acknowledge that the question remained unsettled and that liquidation of the Constitution's meaning on this point was left to subsequent practice. Conversely, when the ratifying conventions do seem to have agreed on some point, the concept of liquidation lets us give that consensus the legal weight that many originalists intuitively believe it deserves.

\section{ORIgINALISM AND THE PASSAGE OF TIME}

The liquidation process permits seemingly intractable disputes about the Constitution's original meaning to evaporate with time. But even for originalists who embrace some version of liquidation, candor requires acknowledgment that the passage of time is a mixed blessing. While a consistent course of interpretation can "fix" the Constitution's meaning on points that once were indeterminate, the passage of time also allows indeterminacies on other points to surface. New situations can force interpreters to confront ambiguities that were merely latent when the Constitution was adopted.

283 See, for example, 5 Annals of Congress at 635 (cited in note 151) (remarks by Rep Edward Livingston on Mar 17, 1796):

As to the construction generally received when the Constitution was adopted, Mr. L did not conceive it to be conclusive, even if admitted to be contrary to that now contended for; because he believed we were now as capable at least of determining the true meaning of that instrument as the Conventions were: they were called in haste, they were heated by party, and many adopted it from expediency, without having fully debated the different articles. But he did not believe the general construction at that time differed from the one he had adopted.

See also Gazette of the United States (Apr 16,1791), reprinted in diGiacomantonio, et al, eds, 14 Documentary History of the First Congress at 471, 471 (cited in note 151) (remarks by Rep John Vining on Feb 8,1791) (asserting that even if the members of the Virginia convention had shared Madison's views about the scope of Congress's powers under the Constitution, "their opinion at that day ... is not a sufficient authority for Congress at the present time to construe the constitution by").

284 For reasons explored in Part I.C, nothing in the logic of originalism necessarily requires them to do so. 
For a simple example of such time-released indeterminacies, recall our discussion of the Cruel and Unusual Punishments Clause. As we saw, modern interpreters who take the "cruel and unusual" formula to refer to the punishment norms of a particular era have disagreed about the era that the formula invokes. ${ }^{225}$ Early interpreters of the Eighth Amendment, however, would not have had to confront this issue; until the punishment norms of their own era had diverged from those of 1791, the question of which era's practices to use as a benchmark was merely academic.

Questions about whether provisions like the Eighth Amendment incorporate fixed or floating benchmarks are not the only kinds of ambiguities that the passage of time can expose. At the time of the founding no less than at other times, many words and phrases surely had what the philosopher Friedrich Waismann called "open texture": English speakers used them without first having devised "rules [ ] for all imaginable possibilities," and future developments could therefore expose latent indeterminacies. ${ }^{286}$ To use Waismann's fanciful example, suppose we see something that looks exactly like a cat, but that subsequently becomes gargantuan or manifests some other trait that we have never before encountered. Assuming that we have not previously decided whether the way in which this creature differs from normal cats affects whether we call it a "cat,", been indeterminate on this point. Similarly, the criteria for the proper application of some of the Constitution's words and phrases surely were not fully specified at the time of the founding.

This is not to say, of course, that all constitutional provisions are indeterminate about all things that were unimaginable in 1788. To pick a random example, originalists can plausibly maintain that the provision empowering Congress " $[\mathrm{t}] \mathrm{o}$ raise and support Armies" guously permits Congress to raise and support forces equipped with automatic weapons, even if such weapons were inconceivable to members of the founding generation. Members of the founding generation may well have understood the word "Armies" to apply without

285 See notes $120-21$ and accompanying text.

286 Friedrich Waismann, Verifiability, Supp 19 Proc Aristotelian Socy 119 (1945), reprinted in G.H.R. Parkinson, ed, The Theory of Meaning 35,37-38 (Oxford 1968). For pointing me to this essay, I am indebted to Michael S. Moore, The Semantics of Judging, 54 S Cal L Rev 151, 201-02 (1981).

287 Even if we never imagined the specific possibility that we have now encountered, our conventional usage of the word "cat" might conceivably have incorporated some closure rules that handle the new situation. For instance, if members of society had tacitly agreed to use the word "cat" to cover all animals that have certain feline properties no matter what other properties they have, then our prior usage of the word would unambiguously cover the newly discovered creature. Conversely, one could imagine a different closure rule that would unambiguously exclude this creature.

288 US Const Art I, § 8, cl 12 . 
regard to the precise nature of a host's weapons (so that forces armed with muskets, bows and arrows, slingshots, or spears could all be called "Armies"). If the word was understood to incorporate this sort of closure rule, then the respect in which forces armed with automatic weapons were inconceivable in 1788 would not affect what originalists think of as the word's "original meaning.",289

Still, changed circumstances certainly do have the potential to expose ambiguities in the Constitution's words and phrases. For a high-profile illustration, consider the constitutionality of race-based affirmative action by state governments. According to Judge Frank Easterbrook, "we do not know (and cannot reconstruct)" whether the Fourteenth Amendment was originally understood to establish a general restraint on state race-consciousness in certain kinds of official actions or instead to establish a narrower rule against "use of race to harm minorities." Judge Easterbrook suggests that because "official action by states favoring racial minorities was unheard of," members of the ratifying society did not appreciate the difference between these two possibilities, and the Amendment's words did not choose between them. If Easterbrook is correct, then the Fourteenth Amendment was open-textured in this respect: The Amendment's original meaning was not specified in sufficient detail to provide a determinate answer about the constitutionality of race-based affirmative action at the state level, but the need for liquidation on this point became apparent only after times changed.

Professor Lawrence Lessig has highlighted another set of interpretive questions that may emerge over time. As he notes, the body of the Constitution was written and adopted under circumstances quite different from those of modern America. Lessig argues that because of this change in circumstances, interpreters may have to do more

289 It is important to understand this claim. When originalists assert that the original meaning of the term "Armies" includes forces equipped with automatic weapons, they are not claiming that English speakers were inevitably going to call such forces "Armies" when automatic weapons were put into use. Except to the extent that later usages of a word can shed light on its earlier meaning, originalists do not care about the current meaning of the word "Armies." Instead, their point is more metaphysical: The original meaning of the word "Armies," as used in Article I, included forces equipped with automatic weapons (or, for that matter, ray guns). If, after the invention of automatic weapons, the term "Armies" was not used to describe forces equipped with them, then the meaning of the term would have changed since 1788 .

It may seem odd to suggest that a word, as it was used in 1788 , can unambiguously refer to things that were unimaginable then. But this idea is not really so odd at all. Suppose that someone in 1900 had referred to "red things, whether past, present, or future." This phrase would surely be understood to focus on color and not on other characteristics. Unless its context implied that some additional properties were also relevant, the utterance would therefore be taken to include red spaceships and other red things whose properties (aside from color) were unimaginable to the speaker.

290 Frank H. Easterbrook, Abstraction and Authority, 59 U Chi L Rev 349, 361 (1992). 
than simply "identify the meaning of the text in its original context.",291 Like people translating a document from one language to another, they may also need to use considerable creativity in identifying a present-day equivalent to that meaning - a rule that comes as close as possible to meaning the same thing in our present circumstances as the original rule meant in the circumstances of the founding. ${ }^{292}$

To a limited extent, all originalists acknowledge the need for some sort of "translation." Originalists emphatically deny that the Constitution should be read like a modern enactment, with whatever meaning its words would have if they were adopted today. Instead, originalists strive to identify and enforce the rules that members of the founding generation would have understood the Constitution to establish. If founding-era usages of a particular word or phrase differed from present-day usages, originalists must find modern terms to describe what the word or phrase would have conveyed to members of the founding generation. Similarly, if interpretive conventions were such that members of the founding generation would have understood the Constitution to establish a particular rule by implication, originalists must make that rule express when they try to articulate the Constitution's original meaning.

Because of his particular view of the "meaning" that present-day interpreters should seek to identify and enforce, however, Professor Lessig's version of translation goes considerably further. Inspired by what Judge Richard Posner calls "imaginative reconstruction,", Lessig suggests that true fidelity to the Constitution's original "meaning" sometimes requires present-day interpreters to go beyond the rules that members of the founding generation actually understood the Constitution to establish, and instead to ask how the Constitution's rules would have been formulated if members of the founding generation had foreseen present-day circumstances. ${ }^{294}$ If one accepts this view

291 Lawrence Lessig, Fidelity and Constraint, 65 Fordham L Rev 1365, 1375 (1997).

292 See Lessig, 71 Tex L Rev at 1263 (cited in note 121). See also Lawrence Lessig, Understanding Changed Readings: Fidelity and Theory, 47 Stan L Rev 395 (1995) (elaborating upon this idea, with specific application to the constitutionality of the New Deal); Lawrence Lessig, Translating Federalism: United States v. Lopez, 1995 Sup Ct Rev 125, 130, 214-15 (describing Lopez as "an act of translation," but criticizing the Court for not being more creative in devising administrable modern rules that reflect the "federalism values" underlying the Constitution).

293 See Richard A. Posner, Statutory Interpretation-In the Classroom and in the Courtroom, $50 \mathrm{U}$ Chi L Rev 800, 817 (1983) (arguing that when required to interpret a statute, "[t] should try to think his way as best he can into the minds of the enacting legislators and imagine how they would have wanted the statute applied to the case at bar").

294 See, for example, Lessig, 71 Tex L Rev at 1166-67 (cited in note 121) (equating originalism with imaginative reconstruction). See also id at 1180-81:

When a presupposition changes, we imagine that the author would have accommodated that change when she first used the text, at least had she had the chance.... If between two contexts a presupposition has changed, then I will say that the same text in the second con- 
of the Constitution's original "meaning," then changes over time will constantly be exposing new indeterminacies in the Constitution. We can never be entirely confident about how the Constitution would have been written (or even whether it would have been ratified) if members of the founding generation had been thinking about situations that did not actually occur to them.

William Michael Treanor has asserted that conventional originalists are logically required to switch to Lessig's approach because "the available evidence suggests that it better reflects the original approach to constitutional interpretation., ${ }^{226}$ Like other purported demonstrations of originalism's self-contradiction, this argument suffers from two flaws: It is not clear that originalists must follow the founders' "interpretive intentions" on this point, ${ }^{297}$ and in any event founding-era interpretive conventions were not as monolithic as Dean Treanor suggests. While Lessig's approach may well be compatible with some founding-era techniques of "equitable construction," those techniques were controversial even as applied to statutes, and early interpreters expressed considerable skepticism about whether they should be applied to the Constitution. ${ }^{298}$ Subsequent liquidation of the relevant interpretive conventions, moreover, has probably cut against equitable construction; some of the uses to which equitable construction was put in founding-era debates sound foreign to modern lawyers. ${ }^{299}$ It should come as no surprise, then, that most originalists reject Professor Lessig's concept of "meaning."

text has a different meaning. And where meaning has changed in this sense, a problem of interpretive fidelity is raised - that is, the reader must accommodate for this changed presupposition if she is to be faithful to the text's original meaning.

295 See id at 1266 ("[T] he problem is always that the task of translation itself is despairingly difficult.”). Compare Frank H. Easterbrook, Statutes' Domains, 50 U Chi L Rev 533, 548 (1983) (explaining why, in the context of statutory interpretation, "judicial predictions of how the legislature would have decided issues it did not in fact decide are bound to be little more than wild guesses").

296 William Michael Treanor, The Original Understanding of the Takings Clause and the Political Process, 95 Colum L Rev 782, 857 (1995).

297 Compare Part I.C (discussing whether the internal logic of originalism requires presentday interpreters to follow founding-era expectations about "liquidation" of the Constitution's meaning).

298 See notes 188 \& 190 (citing examples). See also text accompanying notes 103-13 (suggesting that the framers sought to accommodate unforeseen changes through their initial formulation of rules, rather than by relying upon subsequent interpreters to adjust the formulations appropriately).

299 See, for example, Debates in the Virginia Convention (June 10,1788), in Kaminski and Saladino, eds, 9 Documentary History of the Ratification 1092, 1130 (cited in note 24) (remarks of George Nicholas) (using equitable construction to argue that the Port Preference Clause of Article I, $\S 9-$ which says that "[n]o preference shall be given by any Regulation of Commerce or Revenue to the Ports of one State over those of another"-means that Congress also "cannot give preference to the ports of any foreign nation, over those of a State"). 
Yet even if present-day originalists do not go as far as Professor Lessig, his emphasis on the framers' presuppositions does point to another category of time-released indeterminacies in the Constitution. Some jurisprudential ideas that members of the founding generation expected to stay constant, and that formed the background into which they expected the Constitution to fit, have changed in ways that may make it impossible for certain aspects of the Constitution to work in the way they envisioned. As a result, present-day interpreters may face indeterminacies that members of the founding generation would not have detected.

Consider, for instance, a structural issue of fundamental importance in a federal system composed of distinct states: What respect do the individual states owe to each other's laws? Article IV of the Constitution specifies that "[f]ull Faith and Credit shall be given in each State to the public Acts, Records, and judicial Proceedings of every other State," and it adds that Congress may "prescribe the Manner in which such Acts, Records and Proceedings shall be proved, and the Effect thereof., ${ }^{300}$ For many years, Congress exercised the latter power only partially. Congress established a method for authenticating "the acts of the legislatures of the several states," but it said nothing about their effect. ${ }^{301}$ Even in the absence of congressional action on this point, however, the first part of the Full Faith and Credit Clause appears to be self-executing; the Constitution obliges each state to give "[f]ull Faith and Credit" to the "public Acts" of its sister states.

300 US Const Art IV, $\$ 1$.

301 See Act of May 26, 1790, 1 Stat 122,122. When addressing "the records and judicial proceedings of the courts of any state," Congress did not leave this gap: In addition to specifying how such records and judicial proceedings could be authenticated, it added that they "shall have such faith and credit given to them in every court within the United States, as they have by law or usage in the courts of the state from whence [they] . . are ... taken." Id. Not until the 1948 revision, however, did Congress extend this provision to cover state statutes too. See Act of June 25,1948 , Pub L No $80-773,62$ Stat 869,947 , codified at 28 USC $\$ 1738$ (2000). An argument can be made, moreover, that this way of handling the interstate effect of state statutes is "simply unintelligible." Brainerd Currie, The Constitution and the Choice of Law: Governmental Interests and the Judicial Function, $26 \mathrm{U}$ Chi L Rev 9,19 (1958). If so, then Congress still has failed to prescribe how states must treat the statutes of their sister states.

302 See, for example, Douglas Laycock, Equal Citizens of Equal and Territorial States: The Constitutional Foundations of Choice of Law, 92 Colum L Rev 249, 291-92 (1992) (drawing on both the text and the drafting history of the Full Faith and Credit Clause to argue that "there exists a self-executing obligation to give full faith and credit to sister-state acts"); Ralph U. Whitten, The Original Understanding of the Full Faith and Credit Clause and the Defense of Marriage Act, 32 Creighton L Rev 255, 355 (1998) ("[N]o one in the early days questioned that the first sentence of the Clause was self-executing."). But see Kurt H. Nadelmann, Full Faith and Credit to Judgments and Public Acts: A Historical-Analytical Reappraisal, 56 Mich L Rev 33, 72-73 (1957) (asserting, without presenting much support, that "[f]or about a century after the making of the Constitution, the general view was that, for 'public acts,' the command in the Full Faith and Credit Clause was not self-executing"). 
A species of what used to be called "general" law ${ }^{303}$ was central to the founding generation's expectations about how this obligation would operate. The Full Faith and Credit Clause makes sense only in conjunction with choice-of-law rules specifying which state's statutes control which issues; it would be silly to say that each state's statutes take full effect in every other state. ${ }^{304}$ Modern scholars agree that in the absence of statutory overrides, members of the founding generation expected the necessary choice-of-law rules to come from the general law of nations ${ }^{305}-\mathrm{a}$ body of rules that (they believed) could be derived from the dictates of reason and from common consent manifested by international custom. ${ }^{306}$

According to the dominant modern view of the founding generation's conception, indeed, the Full Faith and Credit Clause affirmatively required states to use these rules of general law (in the absence of appropriate federal legislation) to decide which state's law governed which questions. ${ }^{37}$ If this understanding is correct, ${ }^{308}$ then the

303 See note 138.

304 See Laycock, 92 Colum L Rev at 289 (cited in note 302) (observing that the Full Faith and Credit Clause "is comprehensible only if one assumes a background set of choice-of-law rules").

305 See, for example, Ralph U. Whitten, The Constitutional Limitations on State-Court Jurisdiction: A Historical-Interpretative Reexamination of the Full Faith and Credit and Due Process Clauses (Part One), 14 Creighton L Rev 499,545-46 (1981); Ralph U. Whitten, The Constitutional Limitations on State Choice of Law: Full Faith and Credit, 12 Memphis St U L Rev 1, 33 (1981); Max Rheinstein, The Constitutional Bases of Jurisdiction, 22 U Chi L Rev 775, 802-12 (1955); Crosskey, 1 Politics and the Constitution at 549-50 (cited in note 241).

While modern readers might question the relevance of the law of nations to the relationship among the American states, skepticism on this point does not seem to have occurred to American judges of the late eighteenth century. In thinking about which state's laws governed which questions, they looked quite matter-of-factly to the law of nations. See, for example, Banks v Greenleaf, 2 F Cas 756, 757 (CCD Va 1799) (Washington) ("These laws [of Maryland and Virginia] are contradictory to each other. What, then, says the law of nations upon this subject?"); Millar v Hall, 1 US (1 Dall) 229,232 (Pa 1788) (analyzing the effect of a Maryland insolvency law in a Pennsylvania lawsuit by "consider[ing] the principles of the law of nations, and the reciprocal obligation of the states under the articles of confederation"). See also Crosskey, 1 Politics and the Constitution at 556 (cited in note 241) (observing that "the early state courts [] regarded the conflict of laws, in the rather rare cases in which questions under it arose, as a branch of 'the general law of nations'"); Jay Conison, What Does Due Process Have To Do with Jurisdiction?, 46 Rutgers L Rev 1071, 1104 (1994) ("Because it seemed obvious to treat the United States as a collection of interrelated but sovereign states, it was natural for courts to turn to the law of nations for appropriate principles and rules.") (footnotes omitted).

306 See, for example, James Madison, Examination of the British Doctrine Which Subjects to Capture a Neutral Trade Not Open in Time of Peace (1806), reprinted in 2 Letters and Other Writings of James Madison 227, 262 (J.B. Lippincott 1865) (defining the law of nations as "those rules of conduct which reason deduces, as consonant to justice and common good, from the nature of the society existing among independent nations; with such definitions and modifications as may be established by general consent").

307 See, for example, Laycock, 92 Colum L Rev at 289-30 (cited in note 302) (noting that members of the founding generation expected "the familiar choice-of-law rules then applied in English and American courts" to determine which state's law applied to which questions, and asserting that they understood the Full Faith and Credit Clause to "require courts to apply the law 
passage of time has exposed a serious indeterminacy in the Clause. Most modern lawyers, after all, lack the founding generation's faith in the jurisprudential category of "general law"; we do not expect reason and the custom of nations to provide us with a comprehensive and determinate set of choice-of-law rules. ${ }^{309}$ In the absence of relevant federal legislation, how should modern courts apply the Full Faith and Credit Clause?

One possibility, advocated by various academics, is for the Supreme Court to step into the void left by the collapse of "general law" and to articulate a national set of choice-of-law rules, which the Full Faith and Credit Clause would then be understood to require states to apply. Professor Douglas Laycock argues that because of the Clause, "[w]hether sister-state law applies is a federal question." In the old days, courts would have answered this question by talking about the general law of nations. Now that we have lost faith in the general law, courts must be more self-conscious in "elaborat[ing] a set of federal

of that state"); Rheinstein, 22 U Chi L Rev at 796 (cited in note 305) (agreeing that as applied to "public Acts," the first sentence of the Full Faith and Credit Clause meant that "[f]ull faith and credit shall be given in each State to the public acts of such other State as under the Law of Nations has jurisdiction to legislate on the matter in question"); Crosskey, 1 Politics and the Constitution at 550 (cited in note 241) (concluding that the Clause "mak[es] this whole department of 'the law of nations' a branch of constitutional law, as between our states"). See also Printz v United States, 521 US 898, 907 (1997) (noting that at the time of the framing, laws operating in one state could create obligations that courts of other states would enforce, and adding that the Full Faith and Credit Clause "generally required such enforcement with respect to obligations arising in other states"); Sun Oil Co v Wortman, 486 US 717, 723-24 n 1 (1988) (referring to "the international conflicts law that [the Full Faith and Credit Clause] originally embodied," and asserting that the Clause "made conflicts principles enforceable as a matter of constitutional command rather than leaving enforcement to the vagaries of the forum's view of comity").

308 It might not be. Ralph Whitten has noted that at the time of the founding, English lawyers associated the words "faith" and "credit" with the law of evidence. See Whitten, 12 Memphis St U L Rev at 12 (cited in note 305). In his view, the Constitution's requirement that each state give "[f]ull Faith and Credit" to other states' "public Acts" meant only that each state had to accept documents that purported to be the statutes of another state, and that were authenticated in accordance with the procedures established by Congress, "as conclusive proof that the statutes exist and deal with the matters described in their text." Whitten, 32 Creighton L Rev at 264 (cited in note 302). The remainder of the Full Faith and Credit Clause empowered Congress to specify "the Effect" of such proof, and Congress could use this power to prescribe federal choiceof-law rules that the states would have to follow. See id at 264, 355. But according to Professor Whitten, the Full Faith and Credit Clause did not itself prescribe any such rules or otherwise address "the Effect" of sister-state statutes. While members of the founding generation expected both state and federal courts (in the absence of relevant legislation) to apply the choice-of-law rules that belonged to the law of nations, Professor Whitten maintains that this was not a constitutional obligation, imposed by the Full Faith and Credit Clause. Instead, the general law's choice-of-law rules "operat[ed] outside the Constitution." Id at 336.

309 See, for example, Rheinstein, 22 U Chi L Rev at 797 (cited in note 305) (asking whether international law "contain[s] rules by which the several nations' legislative, judicial and administrative jurisdictions are limited against each other," and concluding that "[a]t present ... no limitations are generally recognized" other than "the principle that no nation's officer is allowed to engage in the exercise of state power within the territory of another"). 
choice-of-law rules," with the Supreme Court getting the last word about the content of the rules. According to Professor Laycock, though, states have no power to prescribe their own choice-of-law rules to deal with the applicability of sister-state law. In the absence of appropriate federal legislation, these issues must be handled by what is now called "federal common law." "310

Another possibility is quite different. Even if one thinks that the Full Faith and Credit Clause gives each state a federal obligation to apply sister-state laws when the law of nations says that they are applicable, no one thinks that the Clause froze the customs of nations as they existed in 1788. But modern international law is thought to contain few choice-of-law rules of universal applicability. Instead, choiceof-law rules are largely seen as "constituting a subject matter of purely national regulation to be established and elaborated by every nation freely for itself." ${ }^{311}$ If the Full Faith and Credit Clause refers states to the law of nations and the modern law of nations refers back to state law, then each state arguably has broad discretion to set its own choice-of-law rules. The same conclusion might also be reached more directly: Even if the Full Faith and Credit Clause requires states to apply sister-state law when the law of nations tells them to do so, the modern law of nations so rarely conveys this instruction that this aspect of the Clause might now impose very few restraints on states.

Modern Supreme Court opinions have fluctuated somewhere between these two extremes. A few cases seem to support the "federal common law" approach. ${ }^{312}$ More recent cases, however, understand the Full Faith and Credit Clause to leave states free to select their own choice-of-law rules as long as they stay within a very broad range. ${ }^{313}$ If one accepts the idea that the Clause incorporated the general law, but

310 See Laycock, 92 Colum L Rev at 301,331-36 (cited in note 302) (resting this conclusion upon both the Full Faith and Credit Clause and the accompanying federal statute, at least as it has stood since 1948). See also Crosskey, 1 Politics and the Constitution at 557 (cited in note 305) (arguing that the Full Faith and Credit Clause, if properly understood, accomplished a "blottingout" of "state legislative power within the field of the interstate conflict of laws"); id at 555 ("[A] single uniform system of nation-wide rules of the interstate conflict of laws is what was intended ....").

311 Rheinstein, $22 \mathrm{U}$ Chi L Rev at 801 (cited in note 241).

312 See, for example, Hughes v Fetter, 341 US 609, 611 (1951) ("[F]ull faith and credit does not automatically compel a forum state to subordinate its own statutory policy to a conflicting public act of another state; rather, it is for this Court to choose in each case between the competing public policies involved.").

313 See Phillips Petroleum Co v Shutts, 472 US 797, 818-22 (1985) (indicating that the Full Faith and Credit Clause imposes only "modest" restrictions on state choice-of-law rules, although holding that Kansas could not apply its own substantive law to "transaction[s] with little or no relationship to the forum"); Allstate Insurance Co v Hague, 449 US 302, 320 (1981) (Brennan) (plurality) (concluding that the Full Faith and Credit Clause did not prevent Minnesota from applying its own law to a controversy, because Minnesota had enough contacts with the parties and the occurrence to make its selection of its own law "neither arbitrary nor fundamentally unfair"). 
agrees that the concept of "general law" has lost its salience over time, then the choice between these disparate approaches is at least contestable. By undermining the presuppositions behind the Full Faith and Credit Clause, the passage of time has exposed an indeterminacy in the Clause's "original meaning.",

For all these reasons, even originalists who embrace the concept of "liquidation" must acknowledge that the Constitution will not necessarily become more and more determinate over time. While a consistent course of interpretation may indeed take some ambiguities off the table, there are a variety of ways in which the passage of time can permit other latent indeterminacies to surface. It follows that even present-day originalists need to decide how to approach unresolved indeterminacies in the Constitution.

Among other things, originalists who embrace the concept of "liquidation" must consider the roles that different institutions should play in the liquidation process. There is no reason to think that every governmental actor who must interpret the Constitution should take an equal part in liquidating its indeterminacies. To the contrary, various commentators have suggested that members of the political branches should play a greater role in liquidating at least some of the Constitution's indeterminacies than members of the federal judiciary.

The modern political-question doctrine effectively takes this position; one of its functions is to distinguish between indeterminacies that the courts will address and indeterminacies whose liquidation they will leave to others. The Supreme Court has identified a few indeterminacies whose resolution the Constitution itself implicitly commits to nonjudicial actors. The Court has held, for instance, that the Constitution empowers the Senate to choose among the various possible understandings of what Article I means by "try[ing]" an impeachment.

314 This particular indeterminacy does not exist if Professor Whitten is correct that the Full Faith and Credit Clause did not incorporate the general law at all. See note 308. Still, other similar examples may well exist. For instance, members of the founding generation may have understood provisions like the Due Process and Takings Clauses to rest upon baseline conceptions of "property" that modern lawyers no longer consider sound. If so, modern lawyers will again have to make contestable choices about how to apply these Clauses.

315 See Rachel E. Barkow, More Supreme than Court? The Fall of the Political Question Doctrine and the Rise of Judicial Supremacy, 102 Colum L Rev 237, 248-53 (2002) (describing and praising the "classical Political Question Doctrine," which "recognized that the Constitution contemplated room for the political actors to give substantive meaning [to the Constitution] within th[e] boundaries [declared by the courts]"); Whittington, Constitutional Interpretation at $221 \mathrm{n} 4$ (cited in note 11) (raising the possibility that courts should not engage in what Whittington calls "constructions" of the Constitution); Easterbrook, $59 \mathrm{U} \mathrm{Chi} \mathrm{L} \mathrm{Rev} \mathrm{at} \mathrm{374-75} \mathrm{(cited} \mathrm{in}$ note 290) ("If the age or generality of the text frustrates the statement of a rule, then it also defeats the claim of judicial power. If the living must indeed chart their own course, then the question is political, outside the domain of judicial review.").

316 See Nixon v United States, 506 US 224, 229-30, 233-36 (1993) (concluding that the Sen- 
Even in the absence of such a "textually demonstrable constitutional commitment of the issue to a coordinate political department," the political-question doctrine lets courts decline to participate in the liquidation process when the choice among permissible interpretations would require "an initial policy determination of a kind clearly for nonjudicial discretion" or when other considerations make it appropriate for courts to bow out of the choice. ${ }^{317}$ Thus, neither the Constitution nor anything else in federal law necessarily requires courts to help liquidate the meaning of each and every ambiguous provision whose liquidation is not affirmatively committed to a specific political branch.

Still, the modern political-question doctrine is fuzzy at best. It suggests that federal courts should play a greater role in liquidating the meaning of some constitutional indeterminacies than others, but it does not give judges a fully satisfying way to decide which indeterminacies are which. Current doctrine identifies some indeterminacies that federal courts are not authorized to address and others that federal courts are required to address in the course of carrying out their duties to adjudicate individual cases. In between these two extremes, though, originalist judges may confront lingering indeterminacy about which indeterminacies the federal judiciary should help to liquidate. As the passage of time uncovers new uncertainties about constitutional interpretation, it will also uncover questions about who should help resolve them.

ate has "final authority to determine the meaning of the word 'try' in the Impeachment Trial Clause"), construing US Const Art I, § 3, cl 6 ("The Senate shall have the sole Power to try all Impeachments.").

317 Baker v Carr, 369 US 186, 217 (1962). 